Arq. Ciên. Mar, 11 ( 1 ): $1-43$

Junho, 1971 - Fortaleza, Ceará, Brasil

\title{
TENTATIVA DE AVALIAÇÃO DOS RECURSOS PESQUEIROS DO NORDESTE BRASILEIRO
}

\author{
Melquíades Pinto Paiva \\ Roberto Cláudio F. Bezerra \\ Antônio Adauto Fonteles-Filho
}

Laboratório de Ciências do Mar

Universidade Federal do Ceará

Fortaleza - Ceará - Brasil

\section{1 - INTRODUÇÃO}

Com o presente trabalho, os autores pretendem avaliar o potencial pesqueiro da região nordeste do Brasil, estabelecendo os níveis de produção de pescado, possíveis de serem atingidos até o ano de 1980 . Ao mesmo tempo, são estudadas as possibilidades de desenvolvimento da exploração dos principais recursos de pesca do nordeste brasileiro.

Consideramos como nordeste do Brasil $x$ área continental que corresponde aos Estados do Maranhão, Piauí, Ceará, Rio Grande do Norte, Paraíba, Pernambuco, Alagoas, Sergipe e Bahia, além daquela insular, que constitui o Território de Fernando de Noronha. Embora parte do Estado de Minas Gerais se inclua no chamado Polígono das Sêcas, não a levamos em consideração, principalmente pelo fato dos dados estatísticos, que são disponíveis e necessários à análise empreendida, abrangerem unidades da federação brasileira, na totalidade das suas áreas.

Em tão vasta região brasileira, cobrind» $18,96 \%$ do território nacional (tabela I), e com $40,78 \%$ do seu litoral continental (tabela II) , a pesca apresenta contrastes marcantes, desde o mais rudimentar primitivismo até a atividade industrial moderna.

\section{2 - BASES NATURAIS DA EXPLORAÇÃO PESQUEIRA}

A produção de massa viva, na qual está incluída a de origem aquática, é o fruto da interação de condições físicas, químicas e biológicas. Sendo assim, elas representam as bases naturais de sustentação da exploração pesqueira.
O conhecimento de tais condições é de fundamental importância para se entender as variações de distribuição e abundância dos recursos pesqueiros, nas águas marinhas, estuarinas e interiores da região em estudo.

O litoral nordestino do Brasil apresenta um tênue recortado, exceto em pequenos trechos, nas proximidades dos seus limites extremos, pouco interrompendo a sua continuidade maciça. A linha de costa mostra duas orientações gerais, que são de grande importância para a compreensão dos fenômenos de circulação marinha.

A deposição de material não se faz igualmente na parte litorânea da região, fato responsável pelas diferenças ocorridas com relação ao traçado da costa, bem como à constituição e extensão da plataforma continental.

O litoral maranhense corresponde ao litoral amazônico oriental, e tem semelhanças com as feições gerais daquêle de tipo amazônico pròpriamente dito, porém apresentando aspectos de submersão. Desde o limite com 0 Estado do Pará até a Ponta dos Mangues, - litoral se caracteriza por apresentar uma costa baixa e recortada, formando verdadeiro rendilhado, envolvendo ilhas, baías, canais e mangues. Da Ponta dos Mangues até as proximidades da Baía de Tutóia, a costa é arenosa e retificada, interrompida sòmente pelos acidentes do delta do Rio Parnaíba.

(1) - Trabalho realizado em decorrência de convênio firmado com o Banco do Nordeste do Brasil S.A., constituindo-se parte do projeto sôbre as Perspectivas do Desenvolvimento do Nordeste até 1980 . 
T A B E L A I

Área geográfica do nordeste brasileiro, e das suas unidades federativas, em valôres absolutos e relativos.

\begin{tabular}{|c|c|c|c|}
\hline \multirow{2}{*}{$\begin{array}{c}\text { Unidades } \\
\text { Regiāo } \\
\text { País }\end{array}$} & \multirow{2}{*}{$\begin{array}{c}\text { Áreas } \\
\text { absolutas } \\
\left(\mathrm{km}^{2}\right)\end{array}$} & \multicolumn{2}{|c|}{$\begin{array}{c}\text { Áreas relativas } \\
(\%)\end{array}$} \\
\hline & & na região & no país \\
\hline $\begin{array}{l}\text { Maranhão } \\
\text { Piaui } \\
\text { Ceará } \\
\text { R. G. do Norte } \\
\text { Paraiba } \\
\text { Pernambuco } \\
\text { Alagoas } \\
\text { Sergipe } \\
\text { Bahia } \\
\text { Minas Gerais * } \\
\text { Fernando de Noronha. }\end{array}$ & $\begin{array}{r}334.809 \\
249.317 \\
153.245 \\
53.048 \\
56.282 \\
98.079 \\
28.531 \\
21.057 \\
563.281 \\
57.328 \\
27\end{array}$ & $\begin{array}{r}20,73 \\
15,44 \\
9,49 \\
3,28 \\
3,48 \\
6,07 \\
1,77 \\
1,30 \\
34,88 \\
3,55 \\
0,01 \\
\end{array}$ & $\begin{array}{l}3,93 \\
2,93 \\
1,80 \\
0,62 \\
0,66 \\
1,15 \\
0,34 \\
0,25 \\
6,61 \\
0,67 \\
0,00\end{array}$ \\
\hline Nordeste & 1.615 .004 & 100,00 & 18,96 \\
\hline BRASIL ** & 8.516 .037 & 一 & 100,00 \\
\hline
\end{tabular}

* Sòmente a área incluída no Poligono das Sêcas.

* Incluindo tôdas as ilhas oceânicas do Brasil.

Fonte: Fundação Instituto Brasileiro de Geografia e Estatística.

T A B E L A I I

Extensāo do litoral continental do nordeste brasileiro, e das suas unidades federativas, em valôres absolutos e relativos.

\begin{tabular}{|c|c|c|c|}
\hline \multirow{2}{*}{$\begin{array}{c}\text { Unidades } \\
\text { Região } \\
\text { País }\end{array}$} & \multirow{2}{*}{$\begin{array}{l}\text { Extensão } \\
\text { absoluta } \\
(\mathrm{km})\end{array}$} & \multicolumn{2}{|c|}{$\begin{array}{c}\text { Extensão relativa } \\
(\%)\end{array}$} \\
\hline & & na região & no país \\
\hline $\begin{array}{l}\text { Maranhão } \\
\text { Piauí } \\
\text { Ceará } \\
\text { R. G. do Norte } \\
\text { Paraiba. } \\
\text { Pernambuco } \\
\text { Alagoas } \\
\text { Sergipe } \\
\text { Bahia }\end{array}$ & $\begin{array}{r}640 \\
65 \\
573 \\
399 \\
130 \\
178 \\
335 \\
163 \\
1.188 \\
\end{array}$ & $\begin{array}{r}17,43 \\
1,77 \\
15,62 \\
10,87 \\
3,54 \\
4,85 \\
9,12 \\
4,44 \\
32,36 \\
\end{array}$ & $\begin{array}{r}7,10 \\
0,71 \\
6,36 \\
4,42 \\
1,45 \\
1,97 \\
3,77 \\
1,80 \\
13,20\end{array}$ \\
\hline Nordeste & 3.671 & 100,00 & 40,78 \\
\hline BRASIL & $\begin{array}{l}7.920 * \\
9.000 * *\end{array}$ & 二 & $10 \overline{0,00}$ \\
\hline
\end{tabular}

* Não incluindo as grandes reentrâncias do litoral brasileiro.

* Incluindo as grandes reentrâncias do litoral brasileiro.

Fonte: Fundação Instituto Brasileiro de Geografia e Estatística.

Entre o delta do Rio Parnaíba e o Cabo de São Roque, o litoral é do tipo semi-árido. As fortes vagas de leste-nordeste, agindo sôbre a plataforma continental pouco profunda e de natureza arenosa, jogim para o litoral uma grande quantidade de material, que se acumula sob a forma de dunas, pela ação dos ventos alísios de sudeste.

No litoral nordeste oriental ou das Barreiras, compreendido entre o Cabo de São Roque e o chamado Recôncavo Baiano, domina um clima super-úmido, não mais havendo acumulação de dunas, com o afloramento d? verdadeiros "tabuleiros", constituídos pelos sedimentos plio-pleistocênicos do Grupo Barreiras. Entre as mais importantes formações geológicas, sotopostas ao Grupo Barreiras, estão as Formações Beberibe, Gramame e Maria Farinha, tôdas no Estado de Pernambuco, e formações cretácicas oleaginosas no Estado da Bahia. É freqüente a presença de arenitos de praia, os chamados recifes, ora constituídos pela diagênese dos sedimentos continentais, ora por cimentação, provocada pela precipitação do carbonato de cálcio da água do mar sôbre as praias arenosas, ou ainda, por diferença de saturação das águas nas desembocaduras dos rios. As maiores concentrações de tais arenitos são encontradas entre as latitudes de $6^{\circ}$ a $10^{\circ} \mathrm{S}$.

Do Recôncavo Baiano até o limite com o Estado do Espírito Santo ocorrem restingas, 
que dão origem a longas planícies, com clima também super-úmido.

A plataforma continental do nordeste brasileiro é relativamente estreita, na maior parte de sua extensão (figura 1 , tabela III) apresentando um limite nítido com o talude continental. Nota-se que, do norte para o sul, vai havendo um estreitamento progressivo da plataforma, variando sua largura desde 120 milhas, no Estado do Maranhão, até 20 milhas em frente de Recife, expandindo-se em seguida, ultrapassando 120 milhas no sul do Estado da Bahia. O limite externo se apresenta sem. pre muito abrupto. Das unidades federativas que compõem o nordeste brasileiro, as que possuem maiores áreas de plataforma são os Estados do Maranhão, Bahia e Ceará, em ordem de importância decrescente (tabela III) .

No Estado do Maranhão, os "waving bottons" são encontrados a partir de São Luís, em direção ao Estado do Pará, formando cristas de areia grossa, quartzosa e incoerente, que atingem desníveis de até 10 metros.

Nos Estados do Ceará e Rio Grande do Norte a plataforma continental se apresenta bem acidentada, em decorrência de fenômenos vulcânicos. Ocorrem altos fundos, que têm analogia com a sua parte externa.

Ao largo do Estado da Bahia também ocorrem planaltos submarinos, na isobata de 50 metros, caindo abruptamente para 400 metros, como é exemplificado pelo Arquipélago dos Abrolhos.

Existem quatro tipos de fácies sedimentares nos fundos da plataforma continental do nordeste brasileiro:

- Fácies litorânea arenosa -_. é constituida por areia quartzosa, com caráter nitidamente litorâneo, a qual varia desde grossa e incoerente até fina e compacta, e cuja distribuição se relaciona com a distância para a costa. Representa a faixa mais larga, ao longo de tôda a plataforma, alcançando sua maior largura em frente ao Estado do Maranhão, reduzindo-se consideràvelmente na parte oriental da região.

- Fácies de algas calcáreas - é um tipo característico do nordeste brasileiro, sendo formada, predominantemente, de algas calcáreas Rhodophyceae. Ocorre em continuação à fácies arenosa, a partir da isobata de $20 \mathrm{me-}$ tros, ocupando tôda a extensão da plataforma, desde o Estado do Piauí até o Estado de Pelnambuco, apresentando-se interrompida na zona de influência do Rio São Francisco. Daí em diante, êste tipo de fácies mostra características diferentes daquelas encontradas até à altura de Recife.

- Fácies organogênica - é constituída por sedimentos arenosos misturados com fragmentos orgânicos diversos (moluscos, corais, briozoários, etc.), caracterizando-se pelo desaparecimento das algas e aumento da porcentagem de lama no sedimento. Ocupa a maior porção da plataforma externa dos Estados do Maranhão e Piauí, e do sul do Estado da Bahia, com ocorrências intercaladas na fácies de algas calcáreas em frente aos Estados do Ceará e Rio Grande do Norte.

- Fácies de lama - é representada por manchas isoladas de pequena extensão, sob a influência direta dos rios costeiros. Está constituída de argila terrígena, com certa quantidade de areia fina quartzosa biodetrítica, com matéria orgânica dispersa. Ocorre principalmente na costa ocidental do Estado do Maranhão e na área adjacente à desembocadura do Rio São Francisco.

As Correntes das Guianas e do Brasil, originadas da Corrente Sul Equatorial, constituem o principal sistema de circulação das águas marinhas na região. Estas correntes se deslocam, principalmente, em direção zonal e são mantidas pelas fôrças motrizes dos ventos predominantes. A Corrente Sul Equatorial tem sua origem nas costas da África, precisamente no Gôlfo da Guiné, alcançando velocidade máxima ao atingir a costa do Brasil, na altura do Cabo de São Roque, por sofrer a ação dos ventos alísios de sudeste, quando se bifurca. dando origem à Corrente das Guianas, que se dirige para noroeste, e à Corrente do Brasil, que se orienta para o sul.

No nordeste brasileiro as principais massas de águas marinhas são representadas pelas águas tropicais, provenientes das Correntes das Guianas e do Brasil, e águas sub-tropicais e intermediárias antárticas, que se deslocam desde o sul do país. As características dessas águas são as seguintes: águas tropicais temperatura em tôrno de $25^{\circ} \mathrm{C}$, salinidad: entre 36,65 e $36,90^{\circ} / 00$, em profundidades de até 200 metros; águas sub-tropicais - temperatura entre $9^{\circ}$ e $12^{\circ} \mathrm{C}$, salinidade em tôrno de $36,18 \%$ oo, em profundidades desde $130-200$ até 600-700 metros; águas intermediárias antárticas - temperatura e salinidade em tôrno de $5,5^{\circ} \mathrm{C}$ e $34,40^{\circ}$ oo, respectivamente, e com cêrca de 500 metros de espessura, ocorrend.) em profundidades a partir de 600-700 metros.

A principal termoclina ocorre em profun. didades de 100-200 metros, coincidindo com a localização do máximo sub-superficial de salinidade. Define-se como termoclina a faixa d’água onde se verifica um considerável gradiente de temperatura, funcionando como divisor ecológico para a distribuição vertical das espécies marinhas.

A produtividade primária e o "standing crop" de zooplâncton, que são os dois primeiros níveis tróficos na produção de massa viva nos ambientes aquáticos, apresentam valôres muito baixos nas águas marinhas do nordes. te do Brasil. A produtividade primária está 


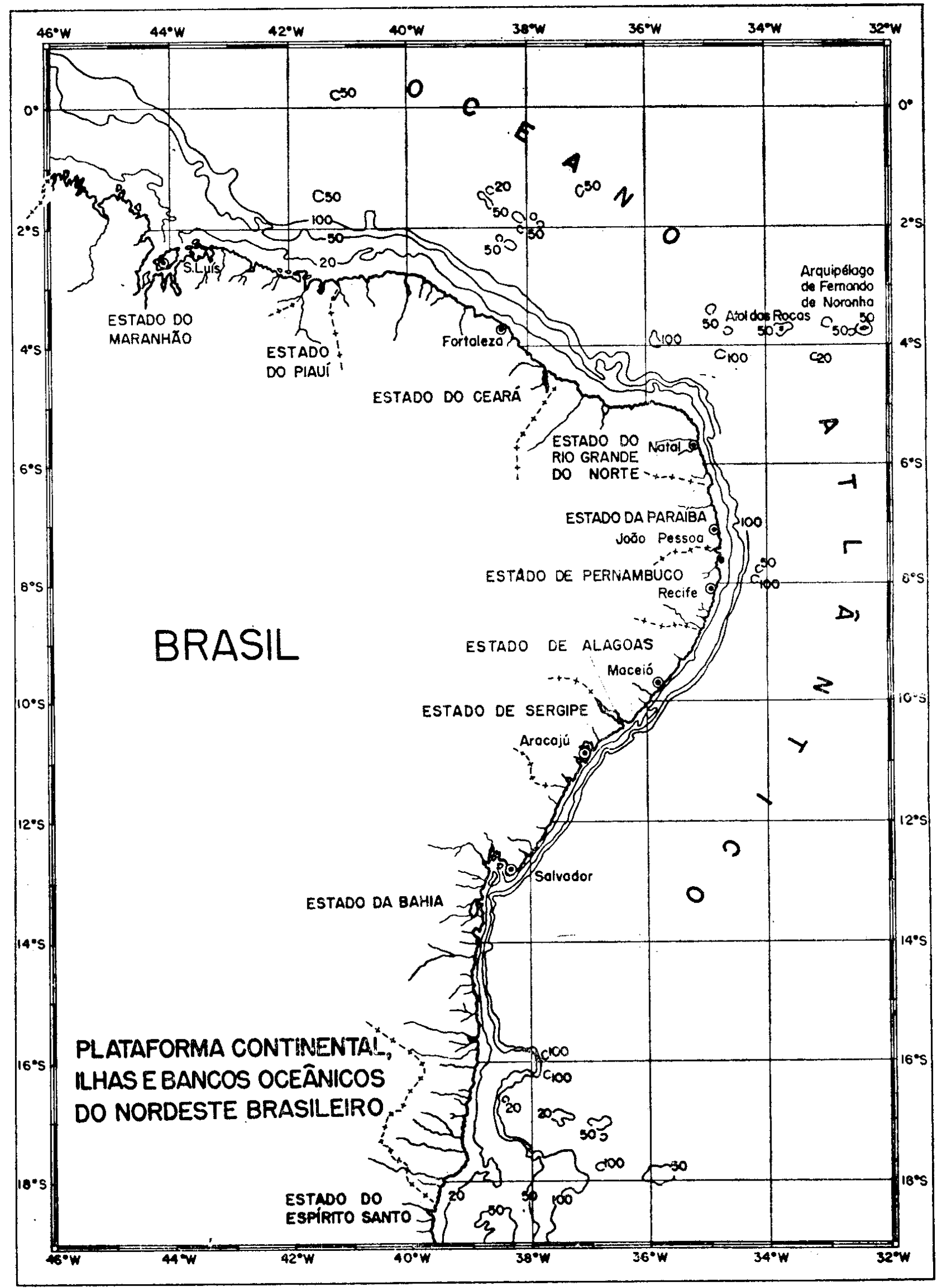

Figura 1 - Plataforma continental, ilhas e bancos oceânicos do nordeste brasileiro. 
T A B E L A I I I

Área da plataforma continental do nordeste brasileiro, por Estados e faixas de profundidades, em milhas quadradas.

\begin{tabular}{|c|c|c|c|c|}
\hline \multirow{2}{*}{$\begin{array}{l}\text { Unidades } \\
\text { Região }\end{array}$} & \multicolumn{3}{|c|}{ Profundidades $(\mathrm{m})$} & \multirow{2}{*}{ TOTAL } \\
\hline & $0-20$ & $20-50$ & $50-100$ & \\
\hline $\begin{array}{l}\text { Maranhão } \\
\text { Piauí } \\
\text { Ceará } \\
\text { R. G. do Norte } \\
\text { Paraíba } \\
\text { Pernambuco } \\
\text { Alagoas } \\
\text { Sergipe } \\
\text { Bahia. }\end{array}$ & $\begin{array}{r}4.881 \\
397 \\
4.656 \\
2.150 \\
380 \\
417 \\
609 \\
400 \\
2.788\end{array}$ & $\begin{array}{r}10.663 \\
532 \\
4.412 \\
1.311 \\
660 \\
933 \\
1.494 \\
496 \\
7.796\end{array}$ & $\begin{array}{r}5.960 \\
318 \\
2.471 \\
358 \\
100 \\
174 \\
286 \\
203 \\
3.963\end{array}$ & $\begin{array}{r}21.504 \\
1.247 \\
11.539 \\
3.819 \\
1.140 \\
1.524 \\
2.389 \\
1.099 \\
14.547\end{array}$ \\
\hline Nordeste & 16.678 & 28.297 & 13.833 & 58.808 \\
\hline
\end{tabular}

Fonte: Diretoria de Hidrografia e Navegação - Ministério da Marinha.

em tôrno de $50 \mathrm{gC} / \mathrm{m}^{2}$ 'ano, e o "standing crop" de zooplâncton não ultrapassa $150 / \mathrm{mg} / \mathrm{m}^{3}$, nos 300 metros superficiais do oceano.

De uma maneira geral, a amplitude das marés no nordeste brasileiro aumenta em direção ao norte do país, atingindo o máximo de 7,8 metros em São Luís.

O território nacional se encontra dividids em 8 grandes bacias hidrográficas, das quais nos interessam, do ponto de vista regional, as seguintes, com suas respectivas áreas: Nordeste - $888.748 \mathrm{~km}^{2}$, São Francisco $631.666 \mathrm{~km}^{2}$ e Leste $-569.845 \mathrm{~km}^{2}$. Estas bacias estão parcialmente incluídas no Poligono das Sêcas, cuja área total corresponde a $1.150 .662 \mathrm{~km}^{2}$. Os rios da região apresentam dois tipos de regime de deságue, diretamente relacionados com as variações climáticas.

$\mathrm{Na}$ Bacia Nordeste, os rios localizados a oeste do Rio Parnaíba são perenes e de cursos relativamente longos, enquanto aquêles que se encontram a leste são temporários. Existem dois coletores principais: o Golfão Maranhense e o Rio Parnaíba.

Os rios que correm para o Golfão Maranhense nascem, geralmente, no alto dos chapadões, e atingem a costa formando estuários que chamam a atenção por sua forma de trombeta, demonstrando a existência de um afogamento. A influência das marés se faz sentir a dezenas de quilômetros rio acima, sendo atenuada pela configuração do relêvo. Os que correm para o Rio Parnaíba seguem, quase todos, direções conseqüentes.

O Rio Parnaíba tem um curso com direção geral sul-norte, apesar de descrever curvas sinuosas em todo o seu trajeto. É um rio de regime quase torrencial, cujas águas atingem o menor volume no período junho-outubro, aumentando ràpidamente a partir de janeiro ou fevereiro.

Os rios que desembocam a leste do Rio Parnaíba, apresentam cursos relativament? curtos, comportando-se de modo diferente, conforme sejam de litoral ou de sertão.

No trecho setentrional, abrangendo os Estados do Ceará e Rio Grande do Norte, de clima sêco, os rios litorâneos e sertanejos são temporários, fluindo sòmente durante a estação chuvosa. A penetração das marés nos vales dos rios impede que os litorâneos percam a comunicação com o mar, durante a estiagem; os sertanejos, no entanto, ficam reduzidos a verdadeiras "estradas" e, quando muito, com uma série de poços isolados.

No trecho oriental, que abrange o litoral desde o sul do Estado do Rio Grande do Norta até o Estado da Bahia, os rios litorâneos são beneficiados pelo regime pluviométrico locaì, tendo suas nascentes na Zona da Mata ou n? Agreste; daí serem permanentes, embora apresentem cursos bastante curtos. Os rios sertanejos são intermitentes, secando durante a estiagem.

A Bacia do São Francisco é constituída pelo Rio São Francisco e seus afluentes, que na área sertaneja são temporários, secando na época da estiagem. As cheias anuais do Rio São Francisco começam em outubro e conti. nuam até abril, atingindo o máximo entre os meses de fevereiro e março; as vazantes correspondem ao período maio-setembro.

As áreas adjacentes às desembocaduras dos rios, chamadas de estuarinas, apresentam águas rasas, de salinidade flutuante e inferior àquela do mar circundante, ricas de sais nutrientes, com alta produtividade biológica. Tais áreas são constituídas, principalmente, por fundos de fácies de lama com mistura de material organogênico, em conseqüência da sedimentação constante de material carregadn pelos rios.

No nordeste brasileiro, as áreas estuarinas mais importantes se localizam nas regiões litorâneas onde ocorre o deságue de rios permanentes, a saber:

- Entre a foz do Rio Gurupi e a Ponta 
dos Mangues - é uma área de litoral bastante recortado, com abundância de canais, ilhas e ilhotas, à semelhança de verdadeiro labirinto, onde se situam amplos manguezais.

- Delta do Rio Parnaíba - apresenta grande diversidade morfológica: o lado ocidental, da Baía de Tutóia até a Baía do Caju, é bastante recortado, com ilhas separadas por canais e com amplos manguezais, mostrando semelhanças com a costa ocidental maranhense; o lado oriental se mostra mais ou menos retificado.

- Área de influência do Rio São Francisco - constituída por suas águas estuarinas e pelo conjunto de amplas lagunas existentes no litoral alagoano, formando uma extensa $e$ rica área de águas estuarinas, sem paralelo dentro do contexto regional.

Afora estas três áreas beneficiadas pelo aporte de rios perenes, o nordeste brasileiro não apresenta condições favoráveis à forma. ção de grandes estuários e, conseqüentemen. te, à acumulação de águas salôbras, com volumes apreciáveis. No entanto, devemos mencionar a zona estuarina do Rio Jaguaribe, no Estado do Ceará, e a sucessão de pequenos estuários, correspondentes aos rios litorâneos do nordeste oriental.

Podemos afirmar que nos rios maranhenses, no Rio Parnaíba e no Rio São Francisco se encontram as mais importantes águas lóticas e permanentes da região nordestina.

Em decorrência do sistema de intermitên. cia da maioria dos rios nordestinos e do fenômeno periódico das sêcas, estabeleceu-se na região uma agressiva política de açudagem, desde o início do presente século. Sòmente o Departamento Nacional de Obras Contra as Sêcas tem a seu crédito a construção de 870 açudes, entre públicos e feitos em regime de cooperação, com a capacidade de $12.572 .891 .976 \mathrm{~m}^{3}$ d'água, até o ano de 1969 (tabela IV), com mais da metade da capacidade armazenadora total no Estado do Ceará. Presentemente, essa importante agência do Govêrno Federal atua em 19 sistemas principais de açudagem, cobrindo uma área com cêrca de $1.000 .000 \mathrm{~km}^{2}$ (tabela V) .

Os açudes se constituem excelentes ambientes para a concentração de recursos naturais vivos, tendo em vista que conservam con dições favoráveis ao desenvolvimento da flora e fauna aquáticas durante o estio, quando os rios periódicos se reduzem a séries de poços.

Por outro lado, os açudes passaram a agir como barreiras para as águas turbulentas dos rios da região que, perdendo o ímpeto, ficam remansosas. A intensificação do deflúvio superficial, conjugada com os fatôres do intemperismo, tornam as águas fluviais ricas em sais minerais dissolvidos e material em suspensão, que são retidos nos açudes. Disto resulta sua elevada produtividade biológica.
T A B E L A I V

Volume de água represada pelo Departamento Nacional de Obras Contra as Sêcas, no Polígono das Sêcas, no período de 1909 a 1969.

\begin{tabular}{|c|c|c|}
\hline Estados & $\begin{array}{l}\text { Açudes } \\
\text { (n) }\end{array}$ & $\begin{array}{c}\text { Capacidade } \\
\left(\mathrm{m}^{3}\right)\end{array}$ \\
\hline $\begin{array}{l}\text { Piauí } \\
\text { Ceará } \\
\text { R. G. do Norte } \\
\text { Paraíba * } \\
\text { Pernambuco ** } \\
\text { Alagoas } \\
\text { Sergipe } \\
\text { Bahia } \\
\text { Minas Gerais } \\
\end{array}$ & $\begin{array}{r}13 \\
485 \\
107 \\
104 \\
44 \\
24 \\
42 \\
47 \\
4\end{array}$ & $\begin{array}{r}182.813 .000 \\
7.812 .172 .631 \\
607.137 .684 \\
2.550 .553 .138 \\
782.505 .696 \\
59.494 .178 \\
19.593 .600 \\
479.506 .049 \\
79.116 .000\end{array}$ \\
\hline TOTAL & 870 & 12.572 .891 .976 \\
\hline
\end{tabular}

* Excluídas 28 aguadas.

** Excluidas 18 aguadas, com a capacidade total de $4.940 .411 \mathrm{~m}^{3}$ d'água

Fonte: Departamento Nacional de Obras Contra as Sêcas.

\section{T A B E L A V}

Frincipais sistemas de açudagem, em operação pelo Departamento Nacional de Obras Contra as Sêcas.

\begin{tabular}{|c|c|c|}
\hline Sistemas & Estados & $\underset{\left(\mathrm{km}^{2}\right)}{\text { Area total }}$ \\
\hline Acaraú & Ceará & 12.540 \\
\hline Apodi & R. G. do Norte & 14.300 \\
\hline Brigida & Pernambuco & 13.000 \\
\hline Contass & Bahia & 52.839 \\
\hline Coreaú & Ceará. & 4.200 \\
\hline Curu & Ceará & 8.500 \\
\hline Garcas & Pernambuco & 4.500 \\
\hline Itapicuru & Bahia. & 36.000 \\
\hline Jaguaribe & Ceará & 80.000 \\
\hline Moxotó & Pernambuco/Alagoas & 9.900 \\
\hline Pajeú & Pernambuco & 16.873 \\
\hline Paraguaçu & Bahia & 53.990 \\
\hline Paraíba & Paraíba & \\
\hline Parnaíba & Ceará/Piauí/Maranhão & 550.000 \\
\hline Piranhas & Paraíba/R. G. do Norte & 44.600 \\
\hline Pontal & Pernambuco & 6.255 \\
\hline Terra Nova & Pernambuco & 6.050 \\
\hline Vaza Barris & Bahia/Sergipe & 18.400 \\
\hline Verde Grande & Bahia/Minas Gerais & 28.800 \\
\hline TOTAL & - & 960.747 \\
\hline
\end{tabular}

Fonte: Departamento Nacional de Obras Contra as Sêcas.

\section{3 - ANÁlise DAS ESTAtfsticAs DE PESCA}

A produção de pescado no nordeste brasiIciro alcançou o total de $1.032 .075 \mathrm{t}$, no período de 1960-1968, correspondendo a $28,6 \%$ da respectiva produção nacional (tabela VI) . Assim, não deixa de ser significativa a participação da região no esfôrço nacional, para o incremento da atividade pesqueira, resultand:s maior volume de capturas.

No contexto regional e no tocante ao volume da produção de pescado, merecem destaque os Estados do Maranhão, Ceará, Paraíba 
e Bahia, em ordem de importância decrescente (tabela VII) . Nas demais unidades, a pesca não tem grande significação, sendo o último lugar ocupado pelo Estado do Piauí.

\section{T A B E L A V I}

Produçāo de pescado na região nordeste e no Brasil, com a participação relativa da região na produção nacional, durante os anos de 1960 a 1968 .

\begin{tabular}{c|r|r|r}
\hline \multirow{2}{*}{ Anos } & \multicolumn{2}{|c|}{ Nordeste } & \multicolumn{1}{c}{ BRASIL } \\
\cline { 2 - 3 } & \multicolumn{1}{c|}{$\mathrm{t}$} & $\%$ & $(\mathrm{t})$ \\
\hline 1960 & 85.285 & 30,3 & 281.512 \\
1961 & 97.796 & 29,6 & 330.140 \\
1962 & 141.537 & 34,1 & 414.640 \\
1963 & 97.667 & 23,2 & 421.356 \\
1964 & 94.882 & 25,2 & 377.008 \\
1965 & 119.685 & 28,3 & 422.289 \\
1966 & 125.610 & 28,7 & 437.787 \\
1967 & 134.262 & 31,2 & 429.422 \\
1968 & 135.351 & 27,0 & 500.387 \\
\hline $1960-1968$ & 1.032 .075 & 28,6 & 3.614 .541 \\
\hline
\end{tabular}

Fonte: Serviço de Estatística da Produção - Ministério da Agricultura.
Considerando o período 1960-1968, כ crescimento da produção regional de pescado se mostrou inferior ao da produção nacional (tabela VIII), evidenciando que não temos podido acompanhar o rítmo de incremento da produção brasileira de pescado, que reflete a adoção de uma política de desenvolvimento das pescas nacionais, estabelecida desde o início da década finda.

Tomando como referência o ano de 1960 (índice $=100$ ), em 1968 as produções nacional e regional de pescado alcançaram os ín. dices 178 e 159 , respectivamente. No ano por último referido, os índices superiores aos registrados para o país, entre as unidades da região, foram os correspondentes aos Estados do Ceará, Bahia e Piauí = Sergipe, em ordem decrescente de importância; o Estado do Maranhão, embora com índice superior ao regional, não alcançou o índice nacional; nas demais unidades, os índices obtidos revelam um pequeno crescimento da produção pesqueira (tabela VIII) .

T A B E I A V I I

Produção de pescado dos diversos Estados do nordeste brasileiro, en valôres relativos ao total regional, durante os anos de 1960 a 1963

\begin{tabular}{|c|c|c|c|c|c|c|c|c|c|c|}
\hline \multirow{2}{*}{$\begin{array}{c}\text { Unidades } \\
\text { Região }\end{array}$} & \multicolumn{9}{|c|}{ Anos } & \multirow{2}{*}{$\begin{array}{c}\text { Periodo } \\
\text { total }\end{array}$} \\
\hline & 1960 & 1961 & 1962 & 1963 & 1964 & 1965 & 1966 & 1967 & 1968 & \\
\hline $\begin{array}{l}\text { Maranhão } \\
\text { Piauí } \\
\text { Ceará } \\
\text { R. G. do Norte } \\
\text { Paraíba } \\
\text { Pernambuco } \\
\text { Alagoas } \\
\text { Sergipe } \\
\text { Bahia }\end{array}$ & $\begin{array}{r}36,4 \\
1,5 \\
12,8 \\
7,8 \\
20,7 \\
5,3 \\
4,6 \\
1,6 \\
9,3\end{array}$ & $\begin{array}{r}37,2 \\
1,2 \\
15,9 \\
5,9 \\
19,9 \\
5,0 \\
4,3 \\
1,6 \\
9,0\end{array}$ & $\begin{array}{r}60,5 \\
1,0 \\
11,5 \\
4,7 \\
8,5 \\
2,0 \\
2,8 \\
1,2 \\
7,8\end{array}$ & $\begin{array}{r}43,7 \\
1,5 \\
21,2 \\
6,6 \\
7,0 \\
3,8 \\
2,7 \\
1,9 \\
11,6\end{array}$ & $\begin{array}{r}41,8 \\
2,0 \\
21,0 \\
6,7 \\
6,3 \\
3,6 \\
3,1 \\
2,1 \\
13,4\end{array}$ & $\begin{array}{r}39,8 \\
1,5 \\
23,8 \\
6,7 \\
7,3 \\
4,8 \\
2,6 \\
1,9 \\
11,6\end{array}$ & $\begin{array}{r}38,7 \\
1,4 \\
18,0 \\
6,9 \\
15,9 \\
3,6 \\
2,3 \\
1,8 \\
11,4\end{array}$ & $\begin{array}{r}39,8 \\
1,8 \\
16,7 \\
9,8 \\
11,9 \\
4,5 \\
3,7 \\
1,8 \\
10,0\end{array}$ & $\begin{array}{r}37,8 \\
1,7 \\
18,6 \\
7,2 \\
14,6 \\
3,6 \\
3,4 \\
1,9 \\
11,2\end{array}$ & $\begin{array}{r}42,3 \\
1,5 \\
17,6 \\
6,9 \\
12,3 \\
3,9 \\
3,2 \\
1,7 \\
10,6\end{array}$ \\
\hline Nordeste & 100,0 & 100,0 & 100,0 & 100,0 & 100,0 & 100,0 & 100,0 & 100,0 & 100,0 & 100,0 \\
\hline
\end{tabular}

Fonte: Serviço de Estatística da Produção - Ministério da Agricultura.

T A B ELA VIII

Indices de crescimento da produção de pescado, por Estados, no total da região nordestina e no Brasil, durante os anos de 1960 a 1968

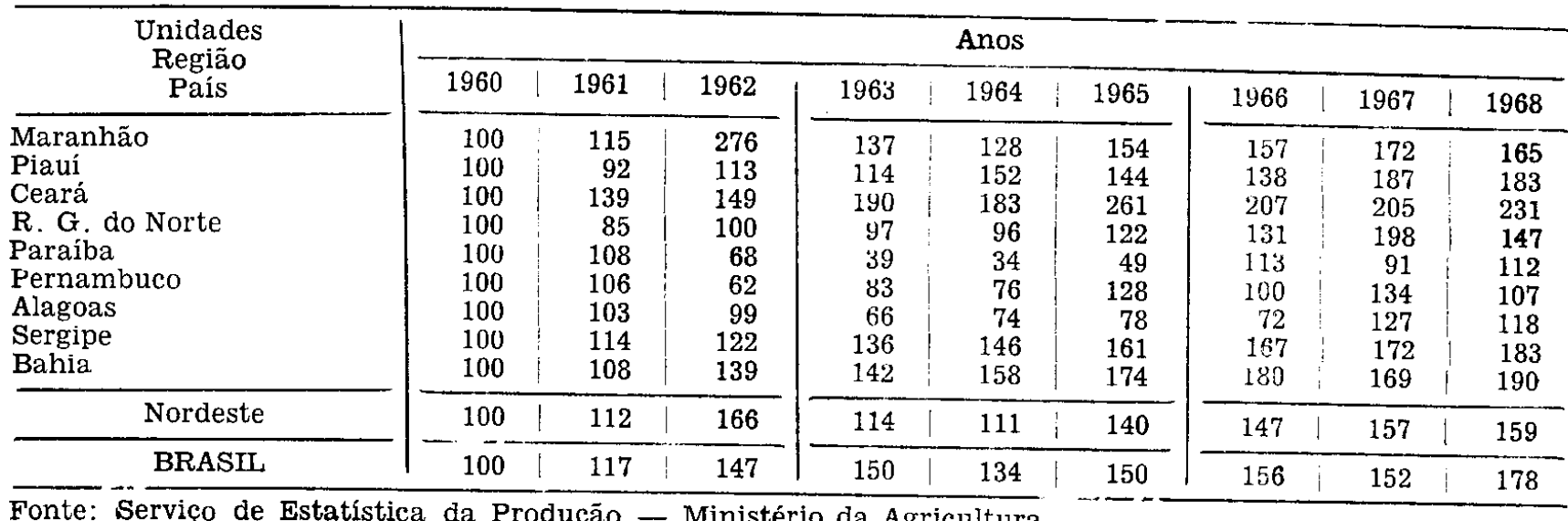

Fonte: Serviço de Estatística da Produçāo - Ministério da Agricultura. 
Uma importante conclusão a tirar, dos dados apresentados, é aquela que define como principais unidades da região, tanto do ponto de vista da produção de pescado como do seu crescimento, os Estados do Maranhão, Ceará e Bahia, onde devem ser concentrados esforços governamentais e empresariais, para a mais rápida promoção do desenvolvimento pesqueiro no nordeste brasileiro.

$\mathrm{Na}$ composição dos desembarques regionais de pescado, predominam dois grupos na. turais - os peixes e os crustáceos, em ordem decrescente de pêso, o mesmo acontecendo com o Brasil; no Estado da Paraíba os mamíferos contribuem com mais da metade da captura, enquanto os moluscos se situam entre os peixes e os crustáceos, no Estado de Alagoas (tabela IX) .

Em têrmos regionais, no período de 1960-1968 , a maior parte da produção de pescado foi de origem marinha, seguindo-se a produção das águas interiores e aquela dos estuários (tabela $\mathrm{X}$ ) . Com base em alguns dados disponíveis e principalmente em nossa própria experiência, podemos afirmar que a produção de pescado nas unidades regionais, segundo sua origem, acompanha o mesmo padrão, exceto nos Estados do Piauí e Alagoas (tabela XI) .

$\mathrm{Na}$ pesca marítima regional coexistem dois sistemas distintos de produção: o artesanal, ao longo de tôda a costa, variando desde a simples atividade de subsistência, praticada com a tecnologia mais rudimentar, até aquela em que a produção já sofre processos de comercialização, sob a liderança de pequenos proprietários ou armadores de embarcações, estas apresentando melhores características pesqueiras e operando com aparelhagem mais moderna; o industrial, caracterizado pela concentração de investimentos em instalações terrestres, operando com embarcações de maior porte, com aparelhagem e métodos de pesca modernos, com seleção de espécies para as capturas.

No sistema artesanal de produção de pescado marinho, no período de 1960-1968, as principais espécies representadas nas capturas regionais, em volume dos desembarques, foram as seguintes: crustáceos - camarões; peixes - bagres, cações, camurupim, cavala, corvina, pescadas, roncador, sardinhas, serra e voador (tabela XII) . No mesmo período, as principais espécies marinhas capturadas pelo sistema industrial de produção de pescado, também em volume dos desembarques, foram as seguintes: crustáceos - lagostas; peixes atuns e pargo; mamíferos — baleias (tabela XIII) .

$\mathrm{Na}$ pesca estuarina regional predomina um grande primitivismo de aparelhos e métodos de exploração, sendo quase sempre uma atividade de subsistência; apenas uma pequena parte da produção sofre processos de comercialização.

No período de 1960-1968, as principais espécies estuarinas capturadas no nordeste brasileiro, em volume de produção, foram as seguintes: crustáceos - caranguejos e siris; moluscos - sururu; peixes - taínhas (tabela XIV).

A pesca em águas interiores da região nordeste do Brasil apresenta características muito variadas, sendo praticada ao longo dos rios e nas reprêsas existentes. Embora quase sempre seja uma atividade rudimentar, de pura subsistência, já se observa um relativo progresso nas pescarias conduzidas nos maiores açudes públicos, não sòmente no tocante aos aparelhos e métodos de captura, como também na comercialização da produção.

Em volume de produção e considerando-se o período de 1960-1968, as principais espécies das águas interiores do nordeste brasileir?

T A B E L A I X

Estimativa da produção de pescado, em valöres relativos, por Estados, na regiāo nordestina e no Brasil, por grandes grupos naturais, no periodo de 1960 a 1968 .

\begin{tabular}{|c|c|c|c|c|c|c|c|}
\hline $\begin{array}{l}\text { Unidades } \\
\text { Região } \\
\text { País }\end{array}$ & $\begin{array}{l}\text { Crustá- } \\
\text { ceos }\end{array}$ & $\begin{array}{l}\text { Molus- } \\
\text { cos }\end{array}$ & Peixes & $\begin{array}{c}\text { Quelô- } \\
\text { nios }\end{array}$ & $\begin{array}{c}\text { IMamí- } \\
\text { feros }\end{array}$ & $\begin{array}{l}\text { Não espe- } \\
\text { cificado }\end{array}$ & Total \\
\hline $\begin{array}{l}\text { Maranhão } \\
\text { Piauí } \\
\text { Ceará } \\
\text { R. G. do Norte } \\
\text { Paraiba } \\
\text { Pernambuco } \\
\text { Alagoas } \\
\text { Sergipe } \\
\text { Bahia }\end{array}$ & $\begin{array}{r}18 \\
5 \\
11 \\
22 \\
20 \\
12 \\
15 \\
48 \\
18\end{array}$ & $\begin{array}{r}0 \\
0 \\
0 \\
0 \\
0 \\
0 \\
31 \\
0 \\
3\end{array}$ & $\begin{array}{l}81 \\
95 \\
89 \\
77 \\
22 \\
84 \\
54 \\
52 \\
79\end{array}$ & $\begin{array}{l}- \\
\overline{0} \\
- \\
-0 \\
0 \\
0 \\
0\end{array}$ & $\begin{array}{l}\overline{-} \\
\overline{5} \\
\overline{5} \\
\overline{0}\end{array}$ & $\begin{array}{l}1 \\
0 \\
0 \\
1 \\
2 \\
4 \\
- \\
0\end{array}$ & $\begin{array}{l}100 \\
100 \\
100 \\
100 \\
100 \\
100 \\
100 \\
100 \\
100\end{array}$ \\
\hline Nordeste & 17 & 1 & 74 & 0 & 7 & 1 & 100 \\
\hline BRASIL & 12 & 1 & 82 & 0 & 4 & 1 & 100 \\
\hline
\end{tabular}

Fonte: Serviço de Estatística da Produção - Ministário da Agricultura. 
foram as seguintes: crustáceos - camarões; peixes - bagres, curimatãs, pescadas, piabas, piáus, sardinhas e traíras (tabela XV).

A estrutura da produção de pescado na região nordestina do Brasil é sustentada, bàsicamente, por dois grandes contingentes: o de pescadores e o de embarcações, ambos de baixa

\section{T A B E L A $\mathrm{X}$}

Estimativa da participação relativa das pescas marítima, estuarina e interior, na produção de pescado da região nordeste do Brasil, no período de 1960 a 1968 .

\begin{tabular}{l|c}
\multicolumn{1}{c|}{$\begin{array}{c}\text { Origem da } \\
\text { produção }\end{array}$} & $\begin{array}{c}\text { Participação } \\
\text { relativa }\end{array}$ \\
\hline marinha & 53 \\
estuarina & 15 \\
interior & 32 \\
\hline \multicolumn{1}{c|}{ TOTAL } & 100 \\
\hline
\end{tabular}

Fonte: Serviço de Estatística da Produção - Ministério da Agricultura/Laboratório de Ciências do Mar - Universidade Federal do Ceará produtividade. Ao lado de certas tendências de desenvolvimento industrial da pesca, persiste aquela em que o crescimento da produção pesqueira resulta do simples aumento vegetativo do número de pescadores e embarcações. O

\section{T A B E L A X I}

Ordem de importância das pescas marítima, estuarina e interior, na produção de pescado dos Estados nordestinos do Brasil, no período de 1960 a 1968 .

\begin{tabular}{l|r|r|r}
\hline \multicolumn{1}{c|}{ Unidades } & \multicolumn{3}{|c}{ Origem da produção } \\
\cline { 3 - 4 } & marinha & estuarina & interior \\
\hline Maranhão & +++ & + & ++ \\
Piauí & + & ++ & +++ \\
Ceará & +++ & + & ++ \\
R. G. do Norte & +++ & + & ++ \\
Paraíba & +++ & + & ++ \\
Pernambuco & +++ & + & ++ \\
Alagoas & ++ & +++ & + \\
Sergipe & +++ & + & ++ \\
Bahia & +++ & + & ++ \\
\hline
\end{tabular}

Fonte: Laboratório de Ciências do Mar - Universidade Federal do Ceará.

T A B E L A XII

Principais espécies marinhas capturadas no nordeste brasileiro, pelo sistema de pesca artesanal, no período de 1960 a 1968 . Unidade $=1$ tonelada.

\begin{tabular}{|c|c|c|c|c|c|c|c|c|c|c|}
\hline \multirow{2}{*}{ Espécies } & \multicolumn{9}{|c|}{ Anos } & \multirow{2}{*}{$\begin{array}{l}\text { Média } \\
\text { anual }\end{array}$} \\
\hline & 1960 & 1961 & 1962 & 1963 & 1964 & 1965 & 1966 & 1967 & 1968 & \\
\hline $\begin{array}{l}\text { Crustáceos } \\
\text { camarōes }\end{array}$ & 7.556 & 7.590 & 14.569 & 5.934 & 4.148 & 9.385 & 10.330 & 11.352 & 9.655 & 8.947 \\
\hline Peixes & & & & & & & & & & \\
\hline bagres & 3.711 & 4.541 & 22.779 & 7.284 & 6.831 & 8.619 & 8.679 & 9.616 & 8.483 & 8.949 \\
\hline caçóes & 271 & 496 & 517 & 633 & 721 & 1.705 & 2.004 & 2.272 & 1.932 & 1.172 \\
\hline camurupim & 1.629 & 1.728 & 5.775 & 4.304 & 944 & 506 & 1.783 & 1.903 & & 2.322 \\
\hline cavala & 467 & 518 & 465 & 678 & 817 & 231 & 401 & 849 & 822 & 583 \\
\hline corvina & 999 & 64 & 74 & 2.402 & 451 & 2.271 & 2.324 & 2.509 & 2.556 & 1.517 \\
\hline pescadas & 104 & 225 & 2.664 & 2.097 & 1.795 & 1.888 & 1.943 & 2.214 & 355 & 1.478 \\
\hline roncador & 734 & 698 & 4.605 & 2.183 & 1.961 & 2.070 & 543 & 2.211 & 2.357 & 1.929 \\
\hline sardinhas & & 409 & 403 & 511 & 458 & 807 & 691 & 921 & 809 & 627 \\
\hline serra & 463 & 366 & 2.773 & 486 & 354 & & 884 & 1.177 & 1.251 & 969 \\
\hline voador & $\ldots$ & 244 & 335 & 349 & 570 & 1.383 & 1.352 & 1.571 & 1.405 & 901 \\
\hline
\end{tabular}

Fonte: Serviço de Estatística da Produção - Ministério da Agricultura.

T A B E L A X I I I

Principais espécies marinhas capturadas no nordeste brasileiro, pelo sistema de pesca industrial, no período de 1960 a 1968 . Unidade $=1$ tonelada

\begin{tabular}{|c|c|c|c|c|c|c|c|c|c|c|}
\hline \multirow{2}{*}{ Espécies } & \multicolumn{9}{|c|}{ Anos } & \multirow{2}{*}{$\begin{array}{l}\text { Média } \\
\text { anual }\end{array}$} \\
\hline & 1960 & 1961 & 1962 & 1963 & 1964 & 1965 & 1966 & 1967 & 1968 & \\
\hline $\begin{array}{c}\text { Crustáceos } \\
\text { lagostas }\end{array}$ & 4.134 & 6.010 & 7.150 & 6.141 & 5.447 & 3.731 & 3.502 & 3.236 & 5.726 & 5.009 \\
\hline $\begin{array}{l}\text { Peixes } \\
\text { atuns } \\
\text { pargo }\end{array}$ & $\begin{array}{r}1.760 \\
292\end{array}$ & $\begin{array}{r}1.377 \\
331\end{array}$ & $\begin{array}{r}3.133 \\
208\end{array}$ & $\begin{array}{r}1.203 \\
496\end{array}$ & $\begin{array}{r}700 \\
1.051\end{array}$ & $\begin{array}{r}207 \\
2.337\end{array}$ & $\begin{array}{l}1.126 \\
3.241\end{array}$ & $\begin{array}{l}1.543 \\
5.115\end{array}$ & $\begin{array}{r}371 \\
3.404\end{array}$ & $\begin{array}{l}1.269 \\
1.775\end{array}$ \\
\hline $\begin{array}{l}\text { Mamiferos } \\
\text { baleias }\end{array}$ & 10.440 & 10.550 & 5.810 & 5.610 & 5.680 & 4.070 & 5.690 & 6.840 & 6.970 & 6.851 \\
\hline
\end{tabular}

Fontes: Serviço de Estatística da Producão - Ministério da Agricultura/Laboratório de Ciências do Mar Universidade Federal do Ceará/Divisão de Recursos Pesqueiros - Superintendência do Desenvolvimento do Nordeste/Delegacia Regional Nordeste Oriental - Superintendência do Desenvolvimento da Pesca. 
T A B E L A X I

Principais espécies estuarinas capturadas no nordeste brasileiro, no periodo de 1960 a 1968 . Unidade $=1$ tonelada.

\begin{tabular}{|c|c|c|c|c|c|c|c|c|c|c|}
\hline \multirow{2}{*}{ Espécies } & \multicolumn{9}{|c|}{ Anos } & \multirow{2}{*}{$\begin{array}{l}\text { Média } \\
\text { anual }\end{array}$} \\
\hline & 1960 & 1961 & 1962 & 1963 & 1964 & 1965 & 1966 & 1967 & 1968 & \\
\hline $\begin{array}{l}\text { Crustáceos } \\
\text { caranguejos } \\
\text { siris } \\
\end{array}$ & $\begin{array}{r}1.529 \\
490\end{array}$ & $\begin{array}{r}3.137 \\
564\end{array}$ & $\begin{array}{r}3.112 \\
626\end{array}$ & $\begin{array}{l}2.809 \\
1.093\end{array}$ & $\begin{array}{r}2.281 \\
742\end{array}$ & $\begin{array}{l}3.215 \\
1.550\end{array}$ & $\begin{array}{r}11.272 \\
1.325\end{array}$ & $\begin{array}{l}8.443 \\
1.455\end{array}$ & $\begin{array}{l}9.848 \\
1.884\end{array}$ & $\begin{array}{l}5.072 \\
1.081\end{array}$ \\
\hline $\begin{array}{l}\text { Moluscos } \\
\text { sururu }\end{array}$ & 3.907 & 3.199 & 2.808 & 1.671 & 2.271 & 4.320 & 2.520 & 2.139 & 1.644 & 2.720 \\
\hline $\begin{array}{l}\text { Peixes } \\
\text { taínhas }\end{array}$ & 3.051 & 4.235 & 13.142 & 5.021 & 4.492 & 4.629 & 5.257 & 8.139 & 6.538 & 6.056 \\
\hline
\end{tabular}

Fontes: Serviço de Estatística da Produção — Ministério da Agricultura/Divisão de Recursos Pesqueiros Superintendência do Desenvolvimento do Nordeste.

T A B E L A X V

Principais espécies de águas interiores capturadas no nordeste brasileiro, no período de 1960 a 1968 . Unidade $=1$ tonelada.

\begin{tabular}{|c|c|c|c|c|c|c|c|c|c|c|}
\hline \multirow{2}{*}{ Espécies } & \multicolumn{9}{|c|}{ Anos } & \multirow{2}{*}{$\begin{array}{l}\text { Média } \\
\text { anual }\end{array}$} \\
\hline & 1960 & 1961 & 1962 & 1963 & 1964 & 1965 & 1966 & 1967 & 1968 & \\
\hline $\begin{array}{l}\text { Crustáceos } \\
\text { camarões }\end{array}$ & 772 & 397 & 473 & 914 & 936 & 823 & 757 & 1.138 & 1.140 & 817 \\
\hline $\begin{array}{l}\text { Peixes } \\
\text { bagres } \\
\text { curimatãs } \\
\text { pescadas } \\
\text { piabas } \\
\text { piáus } \\
\text { sardinhas } \\
\text { traíras }\end{array}$ & $\begin{array}{r}2.749 \\
5.526 \\
155 \\
3.019 \\
1.678 \\
\ldots .79 \\
2.739\end{array}$ & $\begin{array}{r}3.812 \\
8.433 \\
1.240 \\
2.438 \\
559 \\
\ldots .317\end{array}$ & $\begin{array}{r}1.219 \\
9.219 \\
4.123 \\
2.289 \\
845 \\
91 \\
4.817\end{array}$ & $\begin{array}{r}2.812 \\
12.173 \\
1.554 \\
2.257 \\
1.727 \\
130 \\
4.678\end{array}$ & $\begin{array}{l}3.011 \\
9.837 \\
2.968 \\
3.257 \\
2.537 \\
334 \\
5.435\end{array}$ & $\begin{array}{r}2.783 \\
11.693 \\
126 \\
943 \\
3.784 \\
1.179 \\
7.696\end{array}$ & $\begin{array}{r}2.488 \\
9.080 \\
4.418 \\
1.074 \\
2.902 \\
951 \\
5.331\end{array}$ & $\begin{array}{r}1.198 \\
9.131 \\
4.507 \\
194 \\
2.732\end{array}$ & $\begin{array}{r}1.248 \\
9.566 \\
8.173 \\
3.090 \\
2.722 \\
874 \\
6.251\end{array}$ & $\begin{array}{r}2.369 \\
9.406 \\
3.029 \\
2.084 \\
2.165 \\
593 \\
5.253\end{array}$ \\
\hline
\end{tabular}

Fonte: Serviço de Estatística da Produção - Ministério da Agricultura.

desenvolvimento da pesca no nordeste brasilєiro não é um processo harmônico e uniforme, acarretando disparidades dentro da própria região.

\section{4 - RECURSOS PESQUEIROS REGIONAIS}

Os recursos pesqueiros marinhos podem ser classificados em costeiros e oceânicos. A exploração dos primeiros se faz em águas que cobrem as plataformas continentais ou insulares, e ao redor de bancos localizados próximos à costa; a dos segundos, em águas situadas além dos taludes continentais, bem como ao redor de ilhas e bancos oceânicos submersos.

No nordeste brasileiro a pesca em águas costeiras explora recursos pelágicos e demersais, aquêles habitando águas superficiais e êstes vivendo em íntima relação com os fundos da plataforma continental.

Entre os recursos costeiros atualmente conhecidos e explorados industrialmente no nordeste do Brasil, encontram-se apenas as lagostas e o pargo, sendo êste capturado também em águas oceânicas.

Os mais importantes recursos lagosteiros da costa atlântica da América do Sul se con- centram nas águas costeiras do nordeste brasileiro, e passaram a ser explorados a partir de 1955. Nesta região, a pesca industrial de lagostas é realizada em fundos ondulados de algas calcáreas, nas profundidades de 20 a 50 metros. Raramente, realizam-se pescarias em maiores profundidades, embora possam ser $\mathrm{b} \in \mathrm{m}$ produtivas.

A exploração regional de lagostas está bem desenvolvida, constituindo-se, no momento, a mais importante atividade industrial de pesca no nordeste brasileiro. E praticada ao longo da costa dos Estados do Ceará, Rio Grande do Norte, Paraíba e Pernambuco, com limite sul à altura de Recife, em duas áreas bem distintas: nordeste ocidental e nordesta oriental.

A área nordeste ocidental está compreendida entre o delta do Rio Parnaíba e o Cabo de São Roque. Além da ausência de rios permanentes, a extensa e mais larga faixa de fundos de algas calcáreas nesta área favorece a exploração lagosteira, de modo que o volume de produção alcançado sempre se tem mostrado muito superior àquêle obtido na área nordeste oriental. 
A exploração lagosteira no nordeste brasileiro se equipara, do ponto de vista tecnológico, à praticada nos países mais desenvolvidos, no campo das atividades pesqueiras. As operações de pesca são realizadas por modernos barcos motorizados, e a captura é feita através de covos, armadilhas de forma hexagonal, construídas de madeira e revestidas com tela do arame. Os barcos levam de 100 a 400 covos, os quais são lançados ao fundo interligados, em fileiras de 15 a 30 , ou mais, unidades. O esfôrço pesqueiro empregado e os índices de captura alcançam valôres mais elevados $n: \lambda$ área nordeste ocidental, quando comparados com os encontrados para a área nordeste oriental, refletindo-se nas diferenças entre os volumes totais de captura (tabela XVI).

$\mathrm{Na}$ exploração levada a efeito em águas fronteiriças ao nordeste do Brasil, duas espécies de lagostas são capturadas: a lagosta vermelha e a lagosta verde, a primeira com maior participação nos desembarques (tabela XVII).

A lagosta vermelha se concentra em fundos de algas calcáreas, mais afastados da costa, podendo viver em águas mais rasas, desde que não influenciadas pelo aporte de rios. É encontrada em profundidades que variam do 10 a 100 metros. Em pequenas profundidades os indivíduos geralmente são pequenos, porém alcançam comprimentos de até 40 centímetros, em águas mais profundas e afastadas da costa.
A lagosta verde se concentra em fundos de algas calcáreas, mais próximos da costa, podendo viver em águas litorâneas, desde que não influenciadas pelo aporte de rios. E encontrada desde a zona das marés, abrigada em formações rochosas, até a profundidade de 50 metros; mais raramente vive em profundidades superiores. Em pequenas profundidades os indivíduos são pequenos, porém alcançam comprimentos de até 30 centímetros, quando capturados em águas mais afastadas da costa.

No nordeste da América do Sul o pargo se destaca como um dos seus mais importantes recursos pesqueiros. No Brasil esta espécie ocorre desde o Território do Amapá até o Estado do Rio de Janeiro.

A pesca industrial e regional do pargo é realizada desde os Rochedos de São Pedro e São Paulo (latitude $0^{\circ} 55^{\prime} \mathrm{N}-$ longitude $29025^{\prime} \mathrm{W}$ ) até os bancos oceânicos em frent? ao Estado do Ceará, e ao longo da borda do talude continental, desde a parte ocidental do Estado do Ceará até o limite ocidental do Estado do Maranhão. O pargo é também capturado no Arquipélago dos Abrolhos e no $\mathrm{Mar}$ Nôvo, em frente ao Estado da Bahia, sendo a produção desembarcada no Rio de Janeiro (Estado da Guanabara).

A exploração do pargo permitiu a diversificação de atividades das emprêsas lagosteiras, estando sua intensidade relacionada com

\section{T A B E L A X V I}

Dados relativos à pesca de lagostas, nas áreas do nordeste brasileiro, durante os anos de 1965 a 1969 .

\begin{tabular}{|c|c|c|c|c|c|c|}
\hline \multirow{2}{*}{ Anos } & \multicolumn{3}{|c|}{ Nordeste ocidental } & \multicolumn{3}{|c|}{ Nordeste oriental } \\
\hline & $\begin{array}{c}\text { produção * } \\
(t)\end{array}$ & $\begin{array}{c}\text { esfôrço } * * \\
\left(x 10^{*}\right)\end{array}$ & $\begin{array}{c}\text { indice de } \\
\text { captura } \\
\end{array}$ & $\begin{array}{c}\text { produção * } \\
(t)\end{array}$ & $\begin{array}{l}\text { esfôrco } * * \\
\left(\times 10^{6}\right)\end{array}$ & $\begin{array}{l}\text { indice de } \\
\text { captura } * * *\end{array}$ \\
\hline $\begin{array}{l}1965 \\
1966 \\
1967 \\
1968 \\
1969\end{array}$ & $\begin{array}{l}2.764 \\
2.756 \\
2.952 \\
4.948 \\
6.353\end{array}$ & $\begin{array}{r}2,1 \\
3,1 \\
3,9 \\
6,2 \\
11,7\end{array}$ & $\begin{array}{r}1.316 \\
889 \\
757 \\
798 \\
543\end{array}$ & $\begin{array}{r}967 \\
746 \\
284 \\
778 \\
1.551\end{array}$ & $\begin{array}{l}1,1 \\
1,1 \\
0,5 \\
1,6 \\
4,7\end{array}$ & $\begin{array}{l}879 \\
678 \\
567 \\
486 \\
330\end{array}$ \\
\hline
\end{tabular}

* Considerando-se o pèso vivo das capturas.

** Expresso em número de covos/dia utilizados nas pescarias.

*** Expresso em gramas de pêso vivo, nas capturas por unidade de esfôrço.

Fontes: Laboratório de Ciências do Mar - Universidade Federal do Ceará/Divisão de Recursos Pesqueiras - Superintendência do Desenvolvimento do Nordeste.

\section{T A B E L A X V I I}

Estimativas das capturas das lagostas vermelha e verde, nas áreas lagosteiras do nordeste brasileiro, no período de 1965 a 1969

\begin{tabular}{c|c|c|c|c}
\hline \multirow{2}{*}{ Anos } & \multicolumn{2}{|c|}{ Nordeste ocidental } & Nordeste oriental \\
\cline { 3 - 4 } & lagosta vermelha & lagosta verde & lagosta vermelha & lagosta verde \\
\hline 1965 & 1.658 & 1.106 & 580 & 387 \\
1966 & 1.654 & 1.102 & 448 & 298 \\
1968 & 1.771 & 1.181 & 170 & 114 \\
1969 & 3.969 & 1.979 & 467 & 311 \\
\end{tabular}

Fontes: Laboratório de Ciências do Mar - Universidade Federal do Ceará/Divisão de Recursos Pesqueiros - Superintendência do Desenvolvimento do Nordeste. 
as flutuações da produção de lagostas. As pescarias começaram a ter lugar no início da década finda, porém alcançaram maior significação sòmente a partir do ano de 1964 (tabelas XIII e XVIII).

A maior intensidade da exploração pargueira ocorre durante o quarto trimestre do ano, época de maior disponibilidade do recurso para a pesca, fato que se reflete nos maiores índices de captura, que são obtidos neste período.

As pescarias comerciais se realizam em fundos rochosos ou coralinos, principalmente na faixa de profundidades de 40 a 65 braças. As operações são efetuadas por modernos barcos motorizados, com capacidade de porão entre 20 e 50 toneladas, utilizando-se como aparelho de pesca a linha de fundo, construída com fio de nylon e provida de 10 a 15 anzóis.

Com relação aos recursos oceânicos, conhecidos e explorados industrialmente no nordeste brasileiro, podemos destacar apenas as baleias e os atuns.

A pesca industrial de baleias na região foi estabelecida a partir do ano de 1924 , com a implantação de uma base terrestre em Costinha, na margem esquerda do Rio Paraíba, em frente ao pôrto de Cabedêlo, no Estado da Paraíba.

$\mathrm{Na}$ exploração baleeira regional são abatidas as seguintes espécies: baleia espadarte, baleia anã, baleia preta, baleia azul e cachalote. As baleias vivem nas águas antárticas, delas se ausentando durante o inverno, quando migram para águas sub-tropicais, com objetivos de reprodução. O cachalote vive em águas tropicais e migra para as águas sub-tropicais e temperadas, incluindo as antárticas, durante o verão e com os mesmos objetivos. A caça das baleias é uma atividade estacional, desenvolvida no período de junho-novembro,

\section{T A B E L A X I I}

Dados relativos à pesca de pargo no nordeste brasileiro, durante os anos de 1963 a 1969.

\begin{tabular}{c|c|c|c}
\hline Anos & $\begin{array}{c}\text { Produção } \\
(\mathrm{t})\end{array}$ & $\begin{array}{c}\text { Esfôrço } \\
\left(\times 10^{3}\right)\end{array}$ & $\begin{array}{r}\text { Indice de } \\
\text { captura }\end{array}$ \\
\cline { 1 - 2 } 1963 & 496 & 220,3 & 2,25 \\
1964 & 1.051 & 348,1 & 3,02 \\
1965 & 2.337 & 763,6 & 3,06 \\
1966 & 3.241 & $2.843,3$ & 1,14 \\
1967 & 5.115 & $7.307,9$ & 0,70 \\
1968 & 3.404 & $3.781,8$ & 0,90 \\
1969 & 2.640 & $3.300,3$ & 0,80 \\
\hline
\end{tabular}

* Expresso em número de anzóis/hora utilizados nas pescarias.

** Expresso em quilogramas de pêso vivo, nas capturas por unidade de esfôrço.

Fontes: Laboratório de Ciências do Mar - Universidade Federal do Ceará/Divisão de Recursos Pesqueiros - Superintendência do Desenvolvimento do Nordeste.

quando ocorrem as manadas ao largo da costa nordestina do Brasil.

Nesta região os abates de baleias são realizados em águas oceânicas, situadas entre as latitudes de $6^{\circ}$ e $8^{\circ} \mathrm{S}$, a partir da longitude $33^{\circ} \mathrm{W}$ em direção à costa nordestina. Tais abates são feitos por modernos baleeiros, utilizando-se como arma o canhão-arpão.

Dados relativos às estações baleeiras no nordeste brasileiro, nos anos de 1960-1967, são apresentados na tabela XIX. Na distribuição das capturas por espécies (tabela XX), notamos a redução dos abates da baleia espadarte, resultante da diminuição de sua abundância na área, concentrando-se a exploração sôbre a baleia anã, como alternativa possível. Os abates das baleias azul e preta estão internacionalmente proibidos.

A pesca industrial de atuns ao largo $d a$ costa brasileira teve seu início no ano de 1956 , com o baseamento de atuneiros japonêses n; pôrto de Recife. Esta atividade floresceu ràpi-

\section{T A B E L A X I X}

Dados relativos às estações baleeiras no nordeste brasileiro, durante os anos de 1960 a 1967 .

\begin{tabular}{|c|c|c|c|c|c|}
\hline \multirow{2}{*}{ Anos * } & \multicolumn{2}{|c|}{ Baleias } & \multirow{2}{*}{$\begin{array}{c}\text { Porcentagem } \\
\text { de abates }\end{array}$} & \multirow{2}{*}{$\begin{array}{c}\text { Esfôrço } \\
\text { empregado ** }\end{array}$} & \multirow{2}{*}{$\begin{array}{c}\text { Indice de } \\
\text { captura *** }\end{array}$} \\
\hline & avistadas & abatidas & & & \\
\hline $\begin{array}{l}1960 \\
1961 \\
1962 \\
1963 \\
1964 \\
1965 \\
1966 \\
1967\end{array}$ & $\begin{array}{r}1.272 \\
1.103 \\
653 \\
648 \\
613 \\
535 \\
1.071 \\
1.315\end{array}$ & $\begin{array}{l}522 \\
521 \\
285 \\
272 \\
304 \\
229 \\
448 \\
563\end{array}$ & $\begin{array}{l}41,0 \\
47,2 \\
43,6 \\
42,0 \\
49,6 \\
42,8 \\
41,8 \\
42,8\end{array}$ & $\begin{array}{l}248 \\
178 \\
119 \\
124 \\
127 \\
123 \\
161 \\
164\end{array}$ & $\begin{array}{l}2,1 \\
2,9 \\
2,4 \\
2,2 \\
2,4 \\
1,9 \\
2,8 \\
3,4\end{array}$ \\
\hline
\end{tabular}

* Nos anos de 1968 e 1969 foram abatidas 555 e 754 baleias, respectivamente.

* Expresso em número de viagens diárias de baleeiros.

*** Expresso em baleias abatidas por unidade de esfôrço.

Fontes: Laboratório de Ciências do Mar - Universidade Federal do Ceará/Divisão de Recursos Pesqueiros - Superintendência do Desenvolvimento do Nordeste/Delegacia Regional Nordeste Oriental - Superintendência do Desenvolvimento da Pesca. 
damente até o início da década finda, quando entrou em declínio, não por causas naturais, mas tão sòmente por razões de ordem sócio-política, resultando no deslocamento da frota para outras bases, em tôrno do Atlântics Tropical.

Os dados anuais mais recentes de desembarques de atuns no nordeste brasileiro não mostram uma tendência definida, tendo uma distribuição puramente aleatória (tabela XIII) , o que evidencia a inexistência de uma pesca organizada e com suporte próprio.

O método de pesca com espinhel (long-line) é o mais usado para a captura dos atuns de profundidade, tendo sido desenvolvido pelos japonêses. $O$ espinhel é construído, bàsicamente, de seções interligadas, sustentadas por flutuadores de vidro. Cada seção comporta um certo número de linhas secuncárias, às quais estão prêsos os anzóis. A isca comumente utilizada é a "samma", importada do Japão, que propicia boas capturas. No entanto, outras espécies podem ser empregadas, entre as quais nos interessam as agulhas, a sardinha ban. deira e a tilápia.

Nas capturas de atuns no Oceano Atlântico, duas espécies apresentam particular im. portância: a albacora laje e a albacora branca (tabela XXI) .

No Oceano Atlântico existem dois centros de alta abundância aparente da albacora laje, conforme se pode deduzir a partir dos dadoz de captura por unidade de esfôrço, na pesca com espinhel de profundidade: ao norte da América do Sul e nas águas tropicais ao largo da África (figura 2). Estes dois centros sugerem a existência de, pelo menos, duas populações de albacora laje nas águas atlânticas.

A albacora laje é um peixe essencialmente equatorial, que se concentra em águas profundas, formando populações infratermoclinais. Nas águas intertropicais existem populações supratermoclinais.

Na parte ocidental do Atlântico Tropical, a albacora laje é comum desde o Gôlfo do México até Cabo Frio, no Brasil. Apresenta concentração ao longo da costa nordeste da América do Sul, com maior abundância no segundo e terceiro trimestres.

Nas pescarias com espinhel de profundidade, o índice de captura para a albacora laje deve ser igual ou superior a 3 peixes capturados por 100 anzóis/dia, do ponto de vista econômico. O comprimento e pêso má-

T A B E L A X X

Baleias abatidas ao largo do nordeste brasileiro, durante os anos de 1960 a 1969 .

\begin{tabular}{|c|c|c|c|c|c|c|}
\hline Anos & $\begin{array}{c}\text { Baleia } \\
\text { anã }\end{array}$ & $\begin{array}{c}\text { Baleia } \\
\text { azul }\end{array}$ & $\begin{array}{c}\text { Baleia } \\
\text { espadarte }\end{array}$ & $\begin{array}{l}\text { Baleia } \\
\text { preta }\end{array}$ & $\begin{array}{c}\text { Cacha- } \\
\text { lote }\end{array}$ & Total \\
\hline $\begin{array}{l}1960 \\
1961 \\
1962 \\
1963 \\
1964 \\
1965 \\
1966 \\
1967 \\
1968 \\
1969\end{array}$ & $\begin{array}{r}11 \\
1 \\
1 \\
44 \\
71 \\
351 \\
475 \\
452 \\
617\end{array}$ & $\begin{array}{l}- \\
= \\
\overline{1} \\
= \\
-\end{array}$ & $\begin{array}{r}500 \\
508 \\
272 \\
253 \\
256 \\
143 \\
73 \\
55 \\
64 \\
62\end{array}$ & $\begin{array}{r}10 \\
8 \\
8 \\
11 \\
- \\
- \\
13 \\
-\end{array}$ & $\begin{array}{r}1 \\
5 \\
4 \\
7 \\
4 \\
14 \\
24 \\
20 \\
39 \\
75\end{array}$ & $\begin{array}{l}522 \\
521 \\
285 \\
272 \\
304 \\
229 \\
448 \\
563 \\
555 \\
754\end{array}$ \\
\hline
\end{tabular}

Fontes: Laboratório de Ciências do Mar - Universidade Federal do Ceará/Divisão de Recursos Pesquelros - Superintendência do Desenvolvimento do Nordeste/Delegacia Regional Nordeste Oriental - Superintendência do Desenvolvimento da Pesca.

T A B E L A X X I

Capturas estimadas de atuns no Oceano Atlântico, no período de 1960 a 1966 . Unidade $=1.000$ toneladas.

\begin{tabular}{|c|c|c|c|c|c|}
\hline \multirow{2}{*}{ Anos } & \multicolumn{4}{|c|}{ Espécies } & \multirow{2}{*}{ Total } \\
\hline & $\begin{array}{l}\text { albacora } \\
\text { laje }\end{array}$ & $\begin{array}{c}\text { albacora } \\
\text { branca }\end{array}$ & $\begin{array}{c}\text { albacora } \\
\text { olho grande }\end{array}$ & $\begin{array}{l}\text { albacora } \\
\text { azul }\end{array}$ & \\
\hline $\begin{array}{l}1960 \\
1961 \\
1962 \\
1963 \\
1964 \\
1965 \\
1966\end{array}$ & $\begin{array}{l}61,8 \\
53,3 \\
57,5 \\
64,1 \\
68,5 \\
63,7 \\
60,6 \\
\end{array}$ & $\begin{array}{l}54,4 \\
45,5 \\
62,9 \\
67,5 \\
79,2 \\
83,3 \\
72,0 \\
\end{array}$ & $\begin{array}{r}4,6 \\
12,5 \\
20,4 \\
13,8 \\
20,0 \\
35,0 \\
18,0\end{array}$ & $\begin{array}{l}32,0 \\
30,7 \\
45,7 \\
43,8 \\
42,9 \\
37,5 \\
28,0\end{array}$ & $\begin{array}{l}152,8 \\
142,0 \\
186,5 \\
189,3 \\
210,6 \\
219,5 \\
178,6\end{array}$ \\
\hline $1960-1966$ & 429,6 & 464,8 & 124,3 & 260,6 & $1.279,3$ \\
\hline
\end{tabular}

Fonte: Organização de Alimentação e Agricultura - Nações Unidas. 

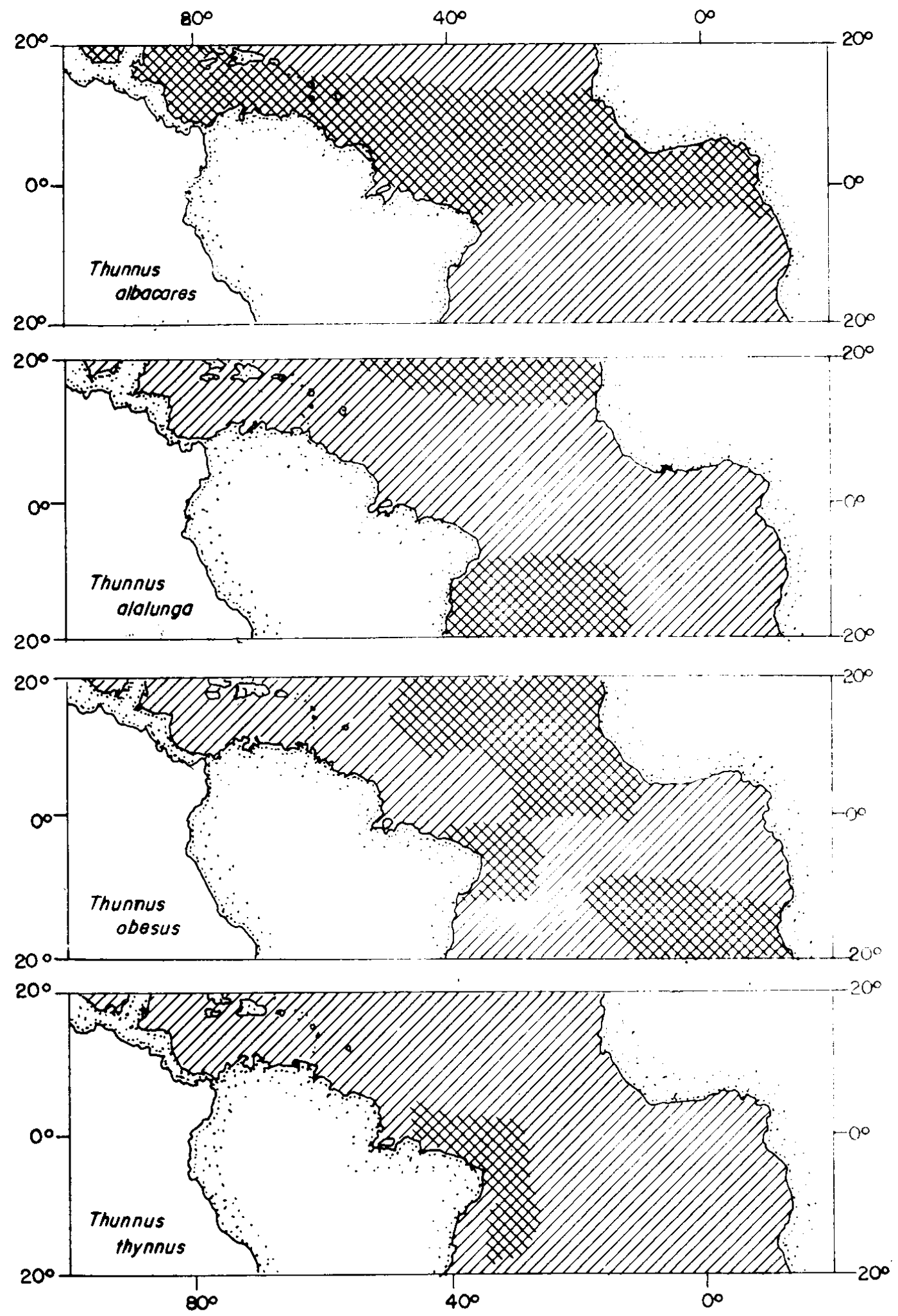

Figura 2 - Areas de distribuição e zonas de concentração das espécies oceânicas de atuns, no Atlântico Tropical. 
ximos da espécie correspondem a 2,5 metros e 200-250 quilos, respectivamente.

Os estoques de albacora laje de maior porte, que suportam a pesca com espinhel de profundidade no Oceano Atlântico, sofreram grandes reduções, em conseqüência da intensa exploração pesqueira. Qualquer aumento no esfôrço de pesca aplicado a esta espécie resultará, na melhor das hipóteses, em apenas um aumento momentâneo do volume de capturas, quando não na diminuição da captura tota!, porém sempre acompanhado de uma progressiva redução da captura por unidade de esfôrço.

No Oceano Atlântico, a ausência ou baixas capturas da albacora branca, ao longo do Equador, sugere $(\mathrm{m})$ a existência de populações distintas desta espécie, em águas dos dois hemisférios (figura 2) .

Com raras exceções, a albacora branca é uma espécie infratermoclinal na zona intertropical do Oceano Atlântico, onde as maiores concentrações conhecidas estão a sudoeste de uma diagonal que corte a zona em duas, ? orientada na direção noroeste-sudeste. Ao longo do nordeste brasileiro, sua maior abundância corresponde ao primeiro e quarto trimestres do ano.

Nas pescarias com espinhel de profundidade, o índice de captura para a albacora branca deve ser igual ou superior a 3 peixes capturados por 100 anzóis/dia, do ponto de vista econômico. O comprimento e pêso máximos da espécie correspondem a 1,5 metros 2 50-60 quilos, respectivamente.

Os estoques da albacora branca, que suportam a pesca com espinhel de profundidade no Oceano Atlântico, estão sendo submetidos a uma pesca intensiva. Qualquer aumento do esfôrço de pesca empregado produzirá um pequeno ou nenhum aumento nas capturas e, certamente, acarretará a redução da captura por unidade de esfôrço, isto principalmente no hemisfério sul.

Já com relação à albacora ôlho grande, parece que suas capturas no Oceano Atlântico podem ser aumentadas, através de um moderado aumento no esfôrço empregado nas pescarias com espinhel de profundidade. No entanto, os estoques passíveis de exploração não são muito extensos.

Ao largo das costas norte e nordeste do Brasil a albacora ôlho grande forma população infratermoclinal, sem grandes concentrações de interêsse pesqueiro (figura 2) .

Nas pescarias com espinhel de profundidade, o índice de captura para a albacora ôlho grande deve ser igual ou superior a 2 peixes capturados por 100 anzóis/dia, do ponto de vista econômico. O comprimento e pêso máximos da espécie correspondem a 2,5 metros e 250-300 quilos, respectivamente.
A albacora azul é uma espécie infratermoclinal na zona intertropical do Oceano Atlântico, e as maiores concentrações para a pesca com espinhel de profundidade se encontram ao sul dos Estados Unidos da América, em maio e junho; ao largo do nordeste brasileiro, em abril e maio (figura 2); e ao oeste da África, de outubro a dezembro.

Nas pescarias com espinhel de profundidade, o índice de abundância para a albacora azul deve ser igual ou superior a 1 peixe capturado por 100 anzóis/dia, do ponto de vista econômico. $\mathrm{O}$ comprimento e pêso máximos da espécie correspondem a 3,5 metros e 600-700 quilos, respectivamente.

$\mathrm{Na}$ exploração atuneira se pratica a pesca de superfície, na captura dos cardumes supratermoclinais, e a pesca de profundidade, quando os cardumes se encontram abaixo da termoclina. No Oceano Atlântico a pesca de profundidade contribuiu com $45,5 \%$ do volume das capturas de atuns, no período de 1960-1966 (tabela XXII) . A albacora laje e a albacora olho grande foram mais atingidas pela pesca de profundidade do que pela de superfície, o contrário acontecendo com a albacora branca e a albacora azul.

De 1956 a 1963, as capturas japonêsas com espinhel de profundidade, no Oceano Atlântico, atingiram 12 milhões de peixes. Neste total, a participação dos atuns foi a seguinte: albacora laje - $52 \%$, albacora branca - 31\% , albacora ôlho grande - 9\% c albacora azul $-1 \%$. O restante correspon. deu a outros peixes oceânicos.

$\mathrm{Na}$ divisão do Oceano Atlântico em áreas atuneiras, duas delas são de particular importância para o Brasil: a área das Guianas, situada entre as longitudes de $35^{\circ}$ e $60^{\circ} \mathrm{W}$, limitando-se com a costa brasileira, alcançando a latitude $5^{\circ} \mathrm{N}$ (na sua parte oriental) e indo até a latitude de $15^{\circ} \mathrm{N}$ (na sua parte ociden. tal); a área da Bahia, situada entre as latitudes $0^{\circ}$ e $20^{\circ} \mathrm{S}$, com limite oriental na lon. gitude de $15^{\circ} \mathrm{W}$ e ocidental na longitude $35^{\circ} \mathrm{W}$ até alcançar a costa brasileira, que passa a lhe servir de limite.

Em ambas as áreas os atuns ocorrem em cardumes localizados abaixo da termoclina, determinando a impossibilidade da pesca de superfície.

Na tabela XXIII apresentamos os valôres anuais correspondentes ao esfôrço de pesca empregado e aos índices de captura, com os respectivos volumes de produção de atuns, na área das Guianas e na área da Bahia, no período de 1956-1963. A produção máxima alcançada na área das Guianas foi a de 1958 , quando atingiu 12.463 toneladas; na área $d a$ Bahia foi a de 1962 , no total de 25.246 toneladas. A albacora laje predomina sôbre a albacora branca na área das Guianas, o con- 
T A B E L A X X I I

Capturas estimađas de atuns no Oceano Atlântico, feitas com espinhel de profundidade, em valôres relativos aos totais, por espécies e no conjunto destas, no período de 1960 a 1966 .

\begin{tabular}{|c|c|c|c|c|c|}
\hline \multirow{2}{*}{ Anos } & \multicolumn{4}{|c|}{ Espécies } & \multirow{2}{*}{ Total } \\
\hline & $\begin{array}{l}\text { albacora } \\
\text { laje }\end{array}$ & $\begin{array}{l}\text { albacora } \\
\text { branca }\end{array}$ & $\begin{array}{c}\text { albacora } \\
\text { olho grande }\end{array}$ & $\begin{array}{c}\text { albacora } \\
\text { azul }\end{array}$ & \\
\hline $\begin{array}{l}1960 \\
1961 \\
1962 \\
1963 \\
1964 \\
1965 \\
1966\end{array}$ & $\begin{array}{l}78,5 \\
76,4 \\
73,4 \\
64,6 \\
60,6 \\
62,8 \\
37,1\end{array}$ & $\begin{array}{l}14,5 \\
16,3 \\
30,2 \\
32,3 \\
50,4 \\
38,3 \\
43,2\end{array}$ & $\begin{array}{l}69,6 \\
89,6 \\
83,8 \\
84,1 \\
86,0 \\
92,9 \\
82,2\end{array}$ & $\begin{array}{r}2,5 \\
1,7 \\
14,0 \\
18,3 \\
20,5 \\
22,4 \\
18,9\end{array}$ & $\begin{array}{l}39,5 \\
42,1 \\
45,4 \\
43,8 \\
50,1 \\
51,4 \\
41,3\end{array}$ \\
\hline $1960-1966$ & 64,5 & 34,2 & 86,6 & 14,7 & 45,5 \\
\hline
\end{tabular}

Fonte: Organização de Alimentação e Agricultura - Nações Unidas.

T A B E L A X X I I I

Dados relativos à pesca de atuns, em águas tropicais do Oceano Atlântico e ao largo das costas norte e nordeste do Brasil, no período de 1956 a 1963 .

\begin{tabular}{|c|c|c|c|c|c|c|}
\hline \multirow{2}{*}{ Anos } & \multicolumn{3}{|c|}{ Área das Guianas } & \multicolumn{3}{|c|}{ Área da Bahia } \\
\hline & $\begin{array}{l}\text { produção } \\
(t)\end{array}$ & $\begin{array}{l}\text { esfôrço * } \\
\left(\times 10^{3}\right)\end{array}$ & $\begin{array}{l}\text { indice de } \\
\text { captura ** }\end{array}$ & $\begin{array}{l}\text { produção } \\
\text { (t ) }\end{array}$ & $\begin{array}{l}\text { esfôrço } \\
\left(\times 10^{3}\right)\end{array}$ & $\begin{array}{l}\text { indice de } \\
\text { captura }\end{array}$ \\
\hline $\begin{array}{l}1956 \\
1957 \\
1958 \\
1959 \\
1960 \\
1961 \\
1962 \\
1963\end{array}$ & $\begin{array}{r}384 \\
2.063 \\
12.463 \\
10.413 \\
7.210 \\
1.683 \\
9.877 \\
7.432\end{array}$ & $\begin{array}{r}82 \\
515 \\
2.663 \\
2.822 \\
2.465 \\
550 \\
3.231 \\
3.303\end{array}$ & $\begin{array}{r}3.0,4 \\
8,9 \\
1.0,4 \\
8,2 \\
6.5 \\
6,8 \\
6,8 \\
5,0\end{array}$ & $\begin{array}{r}50 \\
249 \\
1.354 \\
8.925 \\
12.852 \\
11.387 \\
25.246 \\
13.102\end{array}$ & $\begin{array}{r}19 \\
74 \\
367 \\
2.392 \\
4.543 \\
5.668 \\
13.101 \\
8.194\end{array}$ & $\begin{array}{l}6,4 \\
8,2 \\
9,0 \\
9.1 \\
6,9 \\
4,9 \\
4,7 \\
3,9\end{array}$ \\
\hline
\end{tabular}

* Expresso em número de anzóis/dia utilizados nas pescarias.

** Expresso em peixes capturados por 100 anzóis/dia.

Fontes: Wise, J. P. \& Le Guen, J. C. - 1969 - The Japanese Atlantic long-line fishery 1956 - 1963. Sym. Oceanogr. Fish. Res. Trop. Atlantic, Paris, pp. 317-347, 6 figs./Laboratório de Ciências do Mar - Universidade Federal do Ceará.

trário acontecendo na área da Bahia (tabela XXIV) .

Passaremos agora a tecer comentários sôbre os principais recursos pesqueiros marinhos atualmente explorados pelo sistema de pesca artesanal, no nordeste brasileiro.

Os mais importantes recursos camaroneiros do hemisfério ocidental se encontram nas águas costeiras do nordeste da América do Sul, no trecho localizado entre a desembocadura do Rio Orinoco e a do Rio Parnaíba.

A pesca dos camarões realizada ao longo da costa nordestina do Brasil tem caráter marcadamente artesanal, alcançando maior importância no Estado do Maranhão. Secundàriamente, tem também alguma significação no Estado da Bahia. Nas demais unidades da região as capturas são muito pequenas, embora com algum destaque para os Estados do Rio Grande do Norte e Alagoas.

As características da costa maranhense, pelo traçado do litoral e pelos grandes rios que nela desembocam, asseguram a existência de ambientes particularmente favoráveis aos ca- marões marinhos, de modo que a área da plataforma continental, a ela correspondente, pode ser considerada como uma das mais importantes para a pesca destas espécies, principalmente em fundos mais afastados, pràticamente inexplorados até o presente.

A exploração camaroneira no Estado do Maranhão é muito dispersa, havendo grandes dificuldades para que se processe uma concentração razoável dos desembarques do produto. As áreas de pesca mais promissoras se localizam em frente à costa ocidental, em direção ao Estado do Pará. O período de safra corresponde aos meses de maio a outubro, sendo a totalidade das capturas obtida nos criadouros naturais e/ou em suas proximidades, até a isobata de 20 metros, com alta participação de exemplares jovens. Como aparelhos de pesca são utilizados, principalmente, o puça de espera e o puça de arrasto, que operam em pequenas profundidades.

Desde o Estado de Alagoas até o Estado da Bahia, em virtude da maior largura da plataforma continental e do aporte de rios per- 


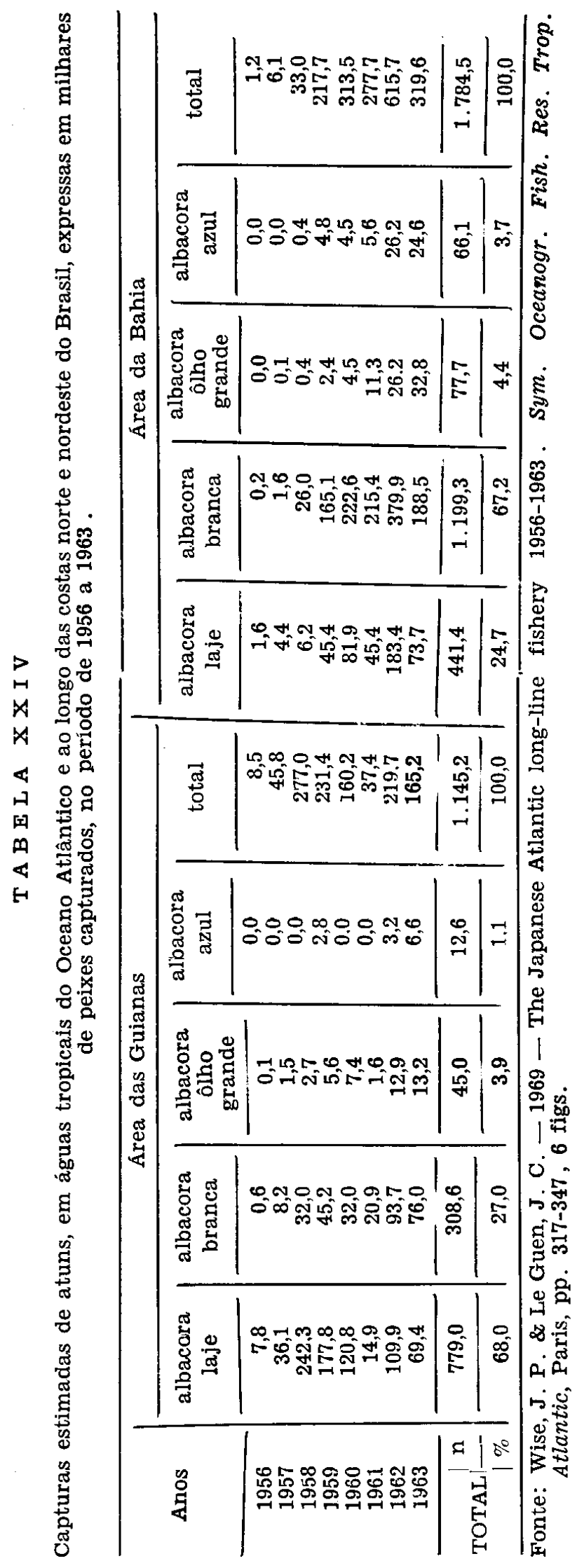

manentes mais caudalosos, também existem condições naturais para o desenvolvimento de populações camaroneiras, principalmente com relação ao camarão sete barbas. Podemos es- perar a implantação de um sistema de exploração industrial de pequeno porte em tôrno da desembocadura do Rio São Francisco, cobrindo uma superfície de 176 milhas quadradas, para a captura da mencionada espécie.

Os camarões constituem-se recursos pesqueiros que vivem em estreita relação com os fundos costeiros, influenciados pelo aporte de rios. No nordeste brasileiro as espécies que participam das capturas comerciais são o camarão sete barbas (camarão piticaia, no Estado do Maranhão), camarão vermelho e camarão branco. A primeira predomina nas capturas, representando mais da metade da produção.

O camarão sete barbas habita os fundos de lama dos estuários, ou mesmo aquêles constituídos por mistura de areia e lama, bem próximos da costa, que sofram a influência do aporte de rios permanentes, onde se constitui a espécie de maior abundância. É encontrado em profundidades que variam de 2 a 20 metros; mais raramente, vive em profundidades de até 50 metros. Nos estuários os exemplares são pequenos, porém alcançam até 10 centímetros de comprimento, quando capturados em águas mais afastadas da costa.

O camarão vermelho habita os fundos de lama dos estuários, no início do seu desenvolvimento, deslocando-se para áreas mais afastadas da costa, constituídas por mistura de lama e areia, onde se torna adulto e atinge comprimentos de até 16 centímetros. E en. contrado em profundidades que variam de 2 a 100 metros, sendo mais abundante além da isobata de 20 metros; mais raramente, vive em profundidades de até 200 metros.

O camarão branco habita também os fundos de lama dos estuários, durante sua fase de jovem, deslocando-se para aquêles constituídos por mistura de lama e areia, mais próximos da costa e ainda sob a influência do aporte de rios, onde se torna adulto e atinge comprimentos de até 22 centímetros. é encontrado em profundidades que variam de 2 a 100 metros.

Devemos considerar com seriedade o desenvolvimento da exploração camaroneira ao longo da costa maranhense. Do ponto de vista natural, o grande obstáculo reside nas dificuldades para a introdução da pesca com rêdes de arrasto nos fundos costeiros em exploração, sendo necessária uma criteriosa prospecção para localizar fundos arrastáveis, em áreas de maior profundidade.

Acreditamos que existem possibilidades para a implantação da pesca industrial de camarões no nordeste brasileiro, em frente ao Estado do Maranhão e a partir da zona de influência do Rio São Francisco, até o limite sul do Estado da Bahia. 
A pesca artesanal de bagres marinhos, embora praticada ao longo de tôda a costa nordeste do Brasil, sòmente alcança grande significação no Estado do Maranhão.

Com exclusão dos camarões, os bagres se constituem os principais recursos pesqueiros explorados ao longo da costa maranhense, onde o recorte do litoral e a drenagem de rios permanentes determinam a formação de fundos de lama em suas proximidades, criando condições favoráveis ao seu desenvolvimento.

Pensamos que a pesca dos bagres marinhos no nordeste brasileiro não tem condições de se transformar numa atividade industrial, embora justifique-se de logo a atenção que ela deve receber, com vistas ao desenvolvimento pesqueiro do Estado do Maranhão.

A pesca artesanal de cações é praticada ao longo de tôda a costa nordestina do Brasil, porém com alguma significação apenas no Estado do Maranhão.

Vasta literatura existe sôbre a abundância de cações ao longo da costa maranhense, embora poucas informações possam ser consideradas de real valor. As capturas são realizadas predominantemente nas proximidades da costa, sendo as fêmeas mais atingidas pela pesca, principalmente na época da reprodução.

Na costa ocidental do Estado do Maranhão, as melhores pescarias de cações, em águas próximas ao litoral, se verificam de janeiro a agôsto; em águas mais profundas, de março a agôsto; e nas proximidades do talude continental, de maio a agôsto.

Embora considerando a exploração dos cações como sem possibilidades de adquirir características industriais na região, acreditamos na abundância dêstes ao longo da costa maranhense, necessitando que se faça uma cuidadosa prospecção do recurso e se introduzam métodos mais modernos para sua captura.

A pesca artesanal do camurupim é realizada ao longo das costas dos Estados do Maranhão ao Ceará, sendo a quase totalidade de sua produção obtida através dos currais-de-pesca.

As capturas do camurupim apresentam bem definida estacionalidade: a safra corresponde aos meses de outubro/novembro a janeiro, e a entresafra ao mês de julho. Durante os meses de outubro/novembro grandes cardumes alcançam a costa ocidental do Estado do Ceará, acreditando os pescadores que procedam dos Estados do Pará e Maranhão e se desloquem próximos à costa, com a finalidade de reprodução, retornando às águas de origem no início de fevereiro, quando se afastam mais da costa. Nos meses de junho a agôsto, pequenos cardumes atingem a costa ocidental cearense, procedendo de águas com alta salinidade.

Durante o primeiro ano de vida o camurupim permanece nas lagoas costeiras, mi- grando para o mar na época das chuvas, quando a conexão dêste com aquelas é restabelecida. Chega a viver 14 anos, alcançando comprimentos ao redor de 2 metros.

Acreditamos que não existem possibilidades de se explorar industrialmente o camurupim na sua área de concentração no nordeste brasileiro, parecendo mesmo que se trata de um recurso de decrescente importância nas pescarias artesanais.

A pesca artesanal da cavala, embora praticada ao longo de tôda a costa do nordeste brasileiro, tem maior significação nos Estados do Ceará, Rio Grande do Norte e Paraíba, principalmente no primeiro.

A cavala é um peixe costeiro, que vive em cardumes na superfície, de regime alimentar puramente carnívoro. Sua captura é realizada em jangadas de piúba ou de tábua, por meio da linha do corso, principalmente nos pesqueiros conhecidos da risca, às vêzes da restinga, e raramente da costa. O período de safra corresponde aos meses de novembro a março, quan. do os cardumes se tornam mais densos e se aproximam da costa em migração genética. Esta espécie chega a viver mais de 12 anos, alcançando comprimentos ao redor de 150 centímetros.

Embora seja a cavala um peixe de alta cotação no mercado regional, além de relativamente abundante nas águas costeiras, onde sua pesca é mais intensa, não acreditamas que venha a ser objeto de exploração industrial, em virtude da pequena densidade dos cardumes e da rapidez com que se deslocam. No entanto, sua exploração deve receber especial atenção, principalmente no Estado do Ceará, através da elevação do nível tecnológico dos métodos de captura, pelo emprêgo do corso múltiplo. Trata-se de um importante recurso a ser levado em consideração, com vistas ao desenvolvimento da pesca artesanal da região em estudo.

A pesca artesanal da corvina é praticada em apenas duas unidades da região nordestina: no Estado do Maranhão, onde tem maior importância, e no sul do Estado da Bahia.

As capturas regionais da corvina são realizadas com rêdes de espera, nos fundos de lama próximos ao litoral, sob a influência de rios permanentes. Tais capturas alcançam indivíduos com até 7 anos, cujos comprimentos se situam em tôrno de 50 centímetros.

A pesca da corvina na costa ocidental do Estado do Maranhão e no sul do Estado da Bahia poderá adquirir maior importância, com a introdução da pesca com rêdes de arrasto, em fundos de lama mais afastados da costa. No entanto, não acreditamos na posșibilidade de desenvolvimento industrial para a exploração desta espécie.

As pescadas são exploradas pela pesca artesanal ao longo de tôda a costa nordestina, 
constituindo-se recursos de maior importância apenas no Estado do Maranhão. Entre as várias espécies capturadas, a pescada amarela é a que apresenta melhor cotação comercial.

Nas' atuais pescarias, as pescadas são capturadas com rêdes de arrasto de praia e rêdes de espera. Com a introdução de aparelhos de arrasto, em áreas de maior profundidade, podemos esperar aumento do volume de capturas das pescadas na parte ocidental do Estado do Maranhão, e no sul do Estado da Bahia. No entanto, não vislumbramos grandes possibilidades para a implantação de um sistema de exploração industrial destas espécies.

O roncador ocorre em todo o nordeste brasileiro, alcançando um significativo volume de capturas apenas no Estado do Maranhão. É uma espécie característica de fundos arenosos ou de lama, localizados próximos à costa, embora não seja raro encontrá-la em fundos rochosos. Sua captura é feita, principalmente, através de armadilhas fixas e de rêdes de arrasto de praia. Esta espécie alcança até 29 centímetros de comprimento, com pêso correspondente de 350 gramas. Não apresenta bom paladar, sendo consumida, principalmente, pelas populações litorâneas.

Não existem possibilidades para a explo ração industrial do roncador, embora se cons. titua um importante recurso da pesca artesanal maranhense, fato que justifica um melhoramento dos métodos empregados na sua captura.

Registram-se capturas de sardinhas, pelo sistema de pesca artesanal, ao longo de tôda a costa do nordeste brasileiro, constituídas, em sua quase totalidade, pela sardinha bandeira. Tais capturas adquirem maior importância desde a costa ocidental do Estado do Ceará até o Estado do Maranhão, sendo efetuadas, prin. cipalmente, através dos currais-de-pesca, atingindo seu maior volume nos meses de maio a julho.

É comum a referência à abundância da sardinha bandeira ao longo da costa maranhense, embora nenhum estudo comprobatório tenha sido levado a efeito, até o presente. $\mathrm{Na}$ hipótese de serem verdadeiros tais informes, o que é bastante provável, tendo-se em vista o volume de capturas obtido pelos currais-de-pesca, o emprêgo de rêdes de cêrco flutuantes, com atração luminosa, poderá determinar um grande aumento da produção, passando a sardinha bandeira a ocupar uma posição de maior destaque nas pescarias artesanais do Estado do Maranhão.

A serra é um peixe capturado artesanalmente ao longo de tôda a costa nordestina, concentrando-se nos Estados do Ceará e Rio Grande do Norte, principalmente no primeiro. Trata-se de uma espécie costeira, que forma cardumes em diferentes profundidades, tendo regime alimentar puramente carnívoro.

As pescarias da serra são realizadas du. rante todo o ano, desde a costa até a risca, em jangadas de piúba ou de tábua, sendo empregados na sua captura três tipos de aparelhos de pesca: a linha de corso, o curral-de-pesca e a rêde de espera. Esta espécie não apresenta um período de safra definido, embora as maiores capturas ocorram nos meses de maio a julho.

A serra chega a viver 10 anos, alcançando comprimentos de até 120 centímetros.

Devemos considerar a serra como um recurso pesqueiro de grande importância, para o desenvolvimento da pesca artesanal da região nordeste do Brasil, principalmente se intensificarmos sua exploração pelo emprêgo de rêdes de espera, que atinjam cardumes em diferentes profundidades. Além dos Estados do Ceará e Rio Grande do Norte, existem con. dições para um bom desenvolvimento da pesca da serra no Estado do Maranhão e no sul d) Estado da Bahia.

$O$ voador constitui-se um dos recursos pesqueiros potencialmente mais importantes do nordeste brasileiro. Ocorre em grande abundância desde o Estado do Maranhão até o Estado de Pernambuco, durante todo o ano, sendo explorado artesanalmente em frente aos Estados do Rio Grande do Norte, Paraíba e Pernambuco, porém com particular importância apenas para o primeiro.

Trata-se de uma espécie que forma grandes e densos cardumes na superfície, em locais que distam de 15 a 100 milhas da costa. Nas atuais pescarias são utilizados botes a vela, de 6 a 9 metros de comprimento, e a captura ́́ feita com jererés, aparelhos constituídos de três varas, dispostas em triângulo, que armam frouxamente uma rêde de malha fina. A época de safra está relacionada com a atividade reprociutiva, ocorrendo nos meses de maio a julho, quando os cardumes se aproximam mais da costa, em migração genética.

Os desembarques do voador no Estado do Rio Grande do Norte são constituídos de indivíduos que têm comprimento e pêso médios em tôrno de 24 centímetros e 140 gramas, respectivamente.

O voador é um recurso cujo potencial deve ser aproveitado, para servir de suporte a uma pesca industrial, sendo necessário que se introduzam, na sua exploração, barcos modernos que operem com rêdes de cêrco flutuante. Afora sua utilização in natura, a ova se constitui um sub-produto importante, atualmente desperdiçado, que é a matéria prima para obtenção de caviar.

Além dos recursos marinhos referidos, alguns outros apresentam possibilidades de ser explorados, tais como as algas, o siri guajá, 
o siri canela, as lulas, os polvos, as agulhas, a albacorinha e a palombeta.

No nordeste brasileiro existem 21 espécies de algas marinhas de interêsse industrial. Destas, pelo menos 11 são aparentemente abundantes. Acreditamos que as algas marinhas podem ser exploradas industrialmente, para a produção de agar-agar, agaróide e mucílagos, desde que se faça uma localização mais acurada dos bancos e se desenvolvam métodos modernos de coleta.

O siri guajá é um caranguejo cuja crescente participação nos desembarques efetuados por barcos lagosteiros, e o valor comercial que tem alcançado no mercado regional, o situam como um dos sub-produtos da exploração lagosteira, com alguma importância industrial.

Habita de preferência os fundos de algas calcáreas, sendo capturado pelos covos empregados na pesca das lagostas. Os maiores índi. ces de captura do siri guajá são obtidos nos meses de janeiro e fevereiro, bem como de agôsto a outubro.

O siri guajá é encontrado em locais cuja profundidade varia de 15 a 100 metros, e nas capturas comerciais os indivíduos apresentam comprimento da carapaça e pêso máximos correspondentes a 13 centímetros e 1,4 quilos, respectivamente. Esta espécie já alcança prêço elevado no mercado regional.

Uma outra espécie, também capturada juntamente com as lagostas, é o siri canela, potencialmente importante para a exploração industrial.

Embora seja encontrado em fundos de areia e lama, o siri canela habita de preferência os de algas calcáreas. Vive em locais com profundidade variando entre 15 e 100 metros e chega a medir 6 centímetros de comprimento.

As lulas são abundantes nas águas oceâ. nicas ao largo do nordeste brasileiro e têm grande importância industrial. Podem ser capturadas à noite, com a utilização de atração luminosa e pequena rêde de cêrco, como atividade complementar da exploração atuneira.

Os polvos vêm sendo capturados pelos covos utilizados na captura de lagostas, podendo ter relativa importância industrial, complementando a exploração lagosteira.

As agulhas são objeto de pesca artesanal ao longo de tôda a costa do nordeste brasileiro, verificando-se uma concentração das pescarias em frente ao Estado de Pernambuco.

A captura destas espécies é feita com uma rêde de cêrco especial, denominada rêde de agulha, em jangadas e botes a vela ou motorizados, durante todo o ano.

Entre as agulhas, merece destaque a agu lha prêta, por sua maior abundância. Esta espécie é planctófaga, reproduzindo-se duranto todo o ano, com mais freqüência nos meses de janeiro-fevereiro e junho-julho. Alcança o comprimento de 20 centímetros, não incluindo o prolongamento do maxilar inferior e a nadadeira caudal.

As agulhas oferecem regulares possibilidades para industrialização, principalmente quando defumadas ou enlatadas, podendo ainda serem transformadas em farinha, na hipótese do substancial incremento das captu. ras. Também servem como iscas para os atuns, nas pescarias com espinhel de profundidade.

A albacorinha é um atum que ocorre em águas costeiras do nordeste brasileiro, principalmente em frente à costa do Estado do Rio Grande do Norte.

A pesca da albacorinha é feita ainda por processos artesanais, com a utilização de barcos a vela e linhas de corso. Em frente a Baía Formosa se estabelece, anualmente, uma pequena frota de barcos a vela, a qual opera somente durante o quarto trimestre, em locais distantes de 12 a 16 milhas da costa. A pesca atinge indivíduos em atividade reprodutiva, que se mantêm na superfície durante o dia, apresentando comprimento e pêso médios de 60 centímetros e 4 quilos, respectivamente.

É certa a ocorrência da albacorinha durante todo o ano ao largo da costa do Estado do Rio Grande do Norte, embora os cardumes se concentrem em locais mais distantes da costa. A exploração dêste recurso tem possibilidades de ser desenvolvida industrialmente, com a utilização de pequenos atuneiros, que operem com rêdes de cêrco flutuante.

A palombeta é relativamente abundante na costa nordestina do Brasil, desde o Estado do Maranhão até o Estado do Ceará, sendo capturada pelos currais-de-pesca e por rêdes de arrasto de praia. No Estado do Ceará esta espécie ocupa o segundo lugar, em volume de capturas, entre aquelas capturadas pelos currais-de-pesca.

Pensamos que a palombeta pode vir a ser um importante recurso da pesca artesanal, desde que se introduzam rêdes de cêrco flutuante, para a sua captura.

Agora vamos tecer alguns comentários sôbre os principais recursos pesqueiros estuarinos do nordeste brasileiro, atualmente explorados pelo sistema de pesca artesanal.

A pesca dos caranguejos, embora prati. cada ao longo de tôda a costa da região, apresenta maior importância nos Estados da Paraíba, Sergipe e Bahia.

A captura é realizada através de coleta manual nas zonas de mangues, e as espécies que se destacam são o guaiamum e o caranguejo uçá.

O guaiamum é uma espécie semi-terrestre, de hábitos mais noturnos que diurnos. Vive nos mangues, ocultando-se em abrigos durante o dia. A alimentação consiste de algas, 
fôlhas e frutos do mangue. Às vêzes é encontrado bastante afastado do mar, regressando na época da reprodução. Alcança até 8 centímetros de comprimento da carapaça, e goza de grande preferência popular, principalmente no Estado de Pernambuco.

O caranguejo uçá também vive nos mangues, porém não muito afastado do mar, em tocas cavadas na lama, que chegam a medir 70 centímetros de profundidade. Tem hábitos noturnos e se alimenta de vegetais ou matéria orgânica em decomposição. Alcança 6 centímetros de comprimento da carapaça, sendo muito consumido na região.

Apesar da pesca dos caranguejos não poder assumir características industriais, o seu aproveitamento na forma de iguarias é recomendável, através do emprêgo de modernos processos tecnológicos.

Nas áreas estuarinas a exploração dos siris é muito freqüente, envolvendo os mais diversos e primitivos métodos de captura. Esta atividade é comum a tôda a região nordestina do Brasil, com destaque ao longo da costa dos Estados da Paraíba e Bahia.

O siri do mangue é a espécie mais importante, neste tipo de pescaria. Habita os mangues e fundos de lama próximos aos estuários, atingindo até 7 centímetros de comprimento da carapaça.

Da mesma forma que a dos caranguejos, a exploração de siris estuarinos não pode assu mir características industriais, o mesmo nã acontecendo com relação à possibilidade do seu aproveitamento, na forma de iguarias.

O sururu é a espécie estuarina de maior importância econômica na região nordestina, alcançando grande volume de produção no Estado de Alagoas, onde se encontra uma das mais importantes reservas naturais conhecidas desta espécie. É capturado também nos Estados do Maranhão e Bahia. porém com pequena significação.

O sururu tem como habitat natural as lagunas costeiras, fixando-se nas margens e bancos mais rasos, em substratos compostos por fragmentos de conchas de moluscos, carapaças de crustáceos e argila síltica que sofreu processo de floculação, havendo também a inclusão de areia quartzosa.

A pesca incide sôbre indivíduos com até 4 centímetros de comprimento, cuja exploraçã ? comercial pode ser realizada a partir dos quatro meses de idade, quando já alcançaram $a$ primeira maturação sexual. A produção está condicionada à entrada de água doce nas lagunas, atingindo seu maior volume nos meses de estiagem (dezembro a março), decrescendo, em seguida, em conseqüência das chuvas, que afetam o processo de fixação. A captura é feita pelo sistema de coleta manual, em pequenas canoas.
Consideramos o sururu um importante recurso pesqueiro, principalmente para o Estado de Alagoas, estando apto a suportar uma exploração de caráter industrial e a fornecer excelente matéria prima para a fabricação de conservas de alto valor comercial.

A pesca das taínhas em águas estuarinas é praticada em tôda a região nordestina, com destaque para o Estado do Maranhão, e secundàriamente, os Estados do Rio Grande dn Norte e Bahia.

As espécies, assim designadas, vivem em águas salobras, dentro dos estuários ou em suas proximidades, sendo capturadas por rêdes de arrasto ou de espera. São os peixes mais abundantes dentro dos viveiros construídos nos estuários, bem como nos tanques das sa linas.

Nos viveiros alcançam até 60 centímetros de comprimento e 4 quilos de pêso. No mar chegam a 1 metro de comprimento, com 6 quilos de pêso. Alimentam-se de microrganismos, principalmente algas e crustáceos.

A pesca e criação das taínhas devem ser fomentadas no Estado do Maranhão e em tôda a costa oriental do nordeste brasileiro. A pesca, pela introdução de modernos métodos de pesca, e a criação em regime intensivo.

Não podemos pensar apenas no seu consumo in natura, mas também no aproveitamento em forma de conservas, principalmente das ovas, das quais se poderá obter excelente produto.

Entre as espécies estuarinas cabe ainda destacar as carapebas, pela abundância com que se apresentam. Isto é particularmente certo com relação aos viveiros de peixes existentes na costa oriental da região.

Por fim, apresentaremos algumas informações sôbre os principais recursos pesqueiros das águas interiores, atualmente explorados no nordeste brasileiro.

Os camarões de água doce são pescados em tôda a região nordestina, com maior importância para os Estados de Pernambuco, Alagoas, Sergipe e Bahia, com relação aos rios permanentes. Além das espécies nativas, entre as quais se destaca o pitu, pequenas espécies amazônicas foram introduzidas nos açudes, onde são exploradas com relativa intensidade.

Estas espécies têm hábitos crepusculares, sendo mais ativas no início e no fim do dia. Vários tipos de aparelhos de pesca são utilizados na sua captura, incluindo a coleta manual, covos, jererés, tarrafas e cestas; dentre êstes destacam-se as tarrafas, por apresentarem um maior rendimento de captura.

Sob a denominação de bagres aqui consideramos os peixes siluriformes, presentes nas águas interiores de tôda a região nordestina do Brasil. No entanto, as maiores capturas dêstes peixes são obtidas nos Estados do 
Maranhão, Piauí, Alagoas, Sergipe e Bahia. As espécies mais importantes para a pesca são as seguintes: cangati, fidalgo, mandi amarelo, pirá e surubim, com especial destaque para o último, por atingir grande tamanho e pelo volume de produção apresentado.

O surubim é encontrado nas grandes bacias hidrográficas de regime permanente do nordeste brasileiro, chegando a atingir $3 \mathrm{me}-$ tros de comprimento. Gosta de freqüentar os fundos dos rios, onde as águas são remansosas. Trata-se de um importante recurso pesqueiro do sistema do Rio São Francisco.

A pesca das curimatãs é praticada em tôda a área continental que constitui o nordeste brasileiro, com destaque para os Estados do Ceará e Maranhão. Além da chamada curimatã comum, muito abundante nos açudes da região, uma outra espécie, nativa do Rio São Francisco - a curimatã pacu, é também capturada, não sòmente no sistema hidrográfico a que pertence, mas também, nos açudes de diversos sistemas hidrográficos da área dos rios periódicos, onde foi introduzida e aclimada.

As curimatãs são os mais importantes recursos pesqueiros das águas interiores do nordeste brasileiro, tanto por serem as que apresentam o maior volume de produção, como por gozarem de grande preferência popular.

As pescadas de águas doces são encontradas nos grandes rios permanentes da região nordestina brasileira. Também foram introduzidas nos açudes da área dos rios periódicos, inclusive com a aclimação de espécies oriundas da Amazônia. A pesca das pescadas é realizada em todo o nordeste do Brasil, principalmente nos Estados do Ceará, Maranhão e Bahia. Para a grande açudagem as pescadas constituem valiosos recursos pesqueiros, não somente pelo volume de capturas, mas também pela alta cotação no mercado regional.

A pesca das piabas alcança alguma significação apenas no Estado do Maranhão, apesar de serem abundantes em tôdas as coleções de águas doces da região em estudo.

Embora a pesca dos piáus seja comum nas águas interiores do nordeste brasileiro, as maiores capturas registradas correspondem aos Estados do Maranhão e Ceará.

Com respeito às sardinhas de água doce, sua pesca tem alguma significação apenas nos açudes do Estado do Ceará.

As traíras representam o segundo mais importante recurso pesqueiro de águas interiores do nordeste, pelo volume de produção que apresentam.

Sob esta denominação estão compreendidas duas espécies: a traíra comum e o jeju. A traíra comum é um peixe de ampla distribuição geográfica, habitando tôdas as coleções de água doce do nordeste brasileiro. O jeju ocorre apenas nos sistemas hidrográficos do regime permanente, principalmente os dos Rios Parnaíba e São Francisco, dentro da área nordestina. As maiores capturas regionais das traíras verificam-se nos Estados do Maranhão e Ceará.

Dentre os recursos pesqueiros âpresentados, provenientes de diferentes ambientes aquáticos, os marinhos constituem-se, indiscutivelmente, os de maior importância, pelas possibilidades que oferecem para a exploração em bases industriais, contribuindo fortemente para o abastecimento do mercado regional, bem como oferecendo excedentes para a exportação. No entanto, não se pode negar a importância dos recursos de águas estuarinas e interiores: os primeiros, fornecendo ocupação e alimento para as populações litorâneas; os segundos, criando uma nova fonte de renda para a propriedade rural no nordeste brasileiro. Tem-se como certo que o valor do pescado capturado durante vinte anos é superior ao que foi dispensado na construção do correspondente açude.

\section{5 - ESTIMATIVAS DAS CAPTURAS}

\section{1 - Pesca industrial}

\section{Lagostas}

A estimação das capturas de lagostas foi feita com base nos dados anuais de esfôrç? pesqueiro empregado e respectivos índices de captura, nas áreas nordeste ocidental e nordeste oriental (tabela XVI) .

Fizemos o ajustamento dos dados ao modêlo do tipo $\mathrm{Y}=\mathrm{a} \mathrm{X}^{\mathrm{b}}$, onde $\mathrm{Y}=$ índice de captura (gramas de lagostas/covo/dia) e $\mathrm{X}=$ esfôrço empregado (covos/dia) - figura 3 .

As equações obtidas foram as seguintes para a área nordeste ocidental _-

$$
\mathrm{Y}=0,67 \cdot 10^{6} \cdot \mathrm{X}^{-0,44}, \mathrm{r}=-0,93^{*} \text {; }
$$

para a área nordeste oriental -

$$
\mathrm{Y}=2,00 \cdot 10^{6} \cdot \mathrm{x}^{-0,57}, \mathrm{r}=-0,90^{*} \text {. }
$$

Usando-se como indice de captura mínimo econômico o de 390 gramas de lagosta/ covo/dia (aproximadamente 1 lagosta/covo/ dia), encontramos os seguintes resultados: para a área nordeste ocidental - esfôrço pesqueiro anual máximo $=22,2 \times 10^{6} \mathrm{covos} / \mathrm{dia}$ e captura anual máxima $=8.658$ toneladas de lagostas; para a área nordeste oriental esfôrço pesqueiro anual máximo $=3,2 \times 10^{6}$ covos/dia e captura anual máxima $=1.248$ toneladas de lagostas; para o nordeste brasileiro - esfôrço pesqueiro anual máximo = 


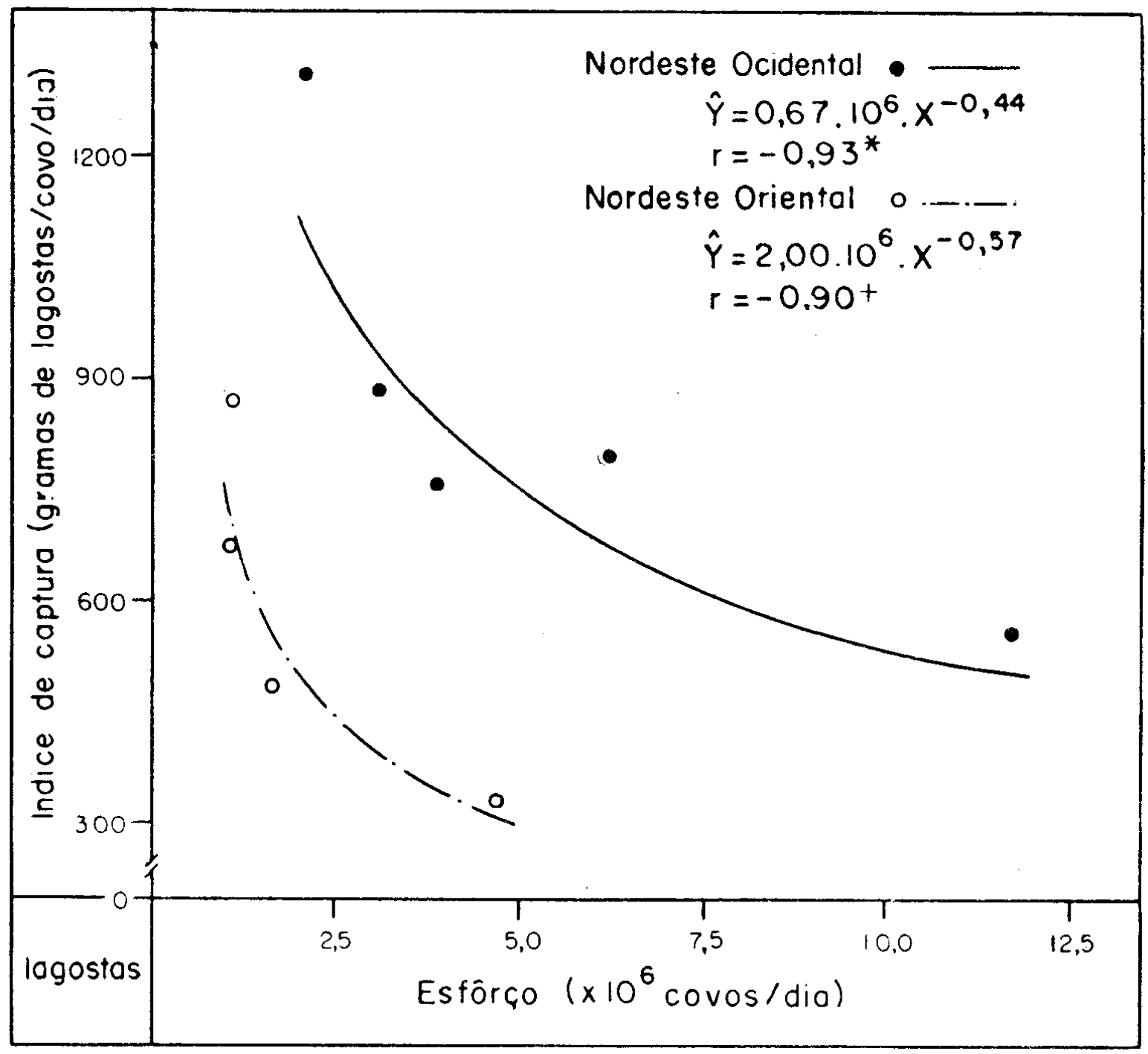

Figura 3 - Curvas de regressão exponencial do índice de captura sôbre o esfôrço, e respectivas equações, relativas à captura de lagostas, nas áreas nordeste ocidental e nordeste oriental.

$25,4 \times 10^{6}$ covos dia e captura anual máxi$\mathrm{ma}=9.906$ toneladas de lagostas .

A captura estimada para o nordeste brasileiro, no ano de 1970 , corresponde a 8.000 toneladas de lagostas, um pouco superior àquela observada no ano anterior (tabela XVI) . Considerando-se que o esfôrço será uniformemente distribuído nas áreas de pesca, como medida de preservação dos estoques, e na hipótese de um aumento constante das capturas até o fim da década, teremos em 1975 a captura de 9.000 toneladas de lagostas, e em 1980 atingiremos a captura anual máxima, que corresponde a 9.900 toneladas. Na hipótese de um desenvolvimento acelerado das capturas, já em 1975 teremos atingido a captura anual máxima, não se esperando posteriores aumento na produção de lagostas.

\section{Atuns}

$\mathrm{Na}$ estimativa das capturas de atuns ao largo do nordeste brasileiro, na hipótese da continuidade da situação anterior (tabela XIII), a captura anual será de aproximadamente 1.300 toneladas, para tôda a década, ou seja, até o ano de 1980 .

Na hipótese da implantação de modernas emprêsas atuneiras no nordeste brasileiro, para a pesca com espinhel de profundidade, a situação se modificará profundamente.

Partindo desta última hipótese, a estimação das capturas foi feita com base nos dados anuais de esfôrço pesqueiro empregado e respectivos índices de captura, na área das Guianas e na área da Bahia (tabela XXIII) .

Fizemos o ajustamento dos dados ao modêlo do tipo $\mathrm{Y}=\mathrm{a}+\mathrm{bX}$, onde $\mathrm{Y}=$ índice de captura (peixes/100 anzóis/dia) e $\mathrm{X}=$ esfôrço empregado (anzóis/dia) — figura 4 .

As equações obtidas foram as seguintes: para a área das Guianas -

$$
\mathrm{Y}=9,25-92 \cdot 10^{-5} . \mathrm{X}, \mathrm{r}=-0,73^{*} ;
$$


para a área da Bahia -

$$
\mathrm{Y}=8,05-33 \cdot 10^{-5} \cdot \mathrm{X}, \mathrm{r}=-0,76^{*} \text {. }
$$

Usando-se como índice de captura minimo econômico o de 5,0 atuns/100 anzóis/dia, encontramos os seguintes resultados: para a área das Guianas - esfôrço pesqueiro anual máximo $=4.620 \times 10^{3}$ anzóis $/$ dia e captura anual máxima $=231.000$ atuns (aproximadamente 11.000 toneladas); para a área da Bahia - esfôrço pesqueiro anual máximo = $9.242 \times 10^{3}$ anzóis/dia e captura anual máxi$\mathrm{ma}=462.000$ atuns (aproximadamente 19.000 toneladas); para o nordeste brasileiro - esfôrço pesqueiro anual máximo $=13.862$ x $10^{3}$ anzóis/dia e captura anual máxima $=693.000$ atuns (aproximadamente 30.000 toneladas).

Nos últimos anos, as capturas de atuns nas áreas acima consideradas, realizadas por embarcações de outros países, têm sido de aproximadamente 15.000 toneladas anuais, segundo dados da Organização de Alimenta. ção e Agricultura das Nações Unidas. Sendo assim, ficam disponíveis outras 15.000 toneladas anuais de atuns, para as capturas das empresas atuneiras que venham a se instalar no nordeste brasileiro.

No entanto, com a não concessão de licenças para operações pesqueiras de embarcações estrangeiras no atual Mar Territorial
Brasileiro, as emprêsas atuneiras que se instalem na região nordestina do Brasil poderão alcançar em 1975 a captura de 15.000 toneladas, chegando-se às 30.000 toneladas de atuns em 1980 .

\section{Pargo}

A estimação das capturas de pargo foi feita com base nos dados anuais de esfôrço pesqueiro empregado e respectivos índices d? captura, para tôda a área do nordeste brasi . leiro (tabela XVIII) .

Fizemos o ajustamento dos dados ao modêlo do tipo $\mathrm{Y}=\mathrm{aX}^{\mathrm{b}}$, onde $\mathrm{Y}=$ índice de captura (quilos/anzol/hora) e $\mathrm{X}=$ esfôrço empregado (anzóis/hora) - figura 5 .

A equação obtida foi a seguinte:

$$
\mathrm{Y}=738 \cdot \mathrm{X}^{-0,44}, \mathrm{r}=-0,91^{*} \text {. }
$$

Usando-se como índice de captura minimo econômico o de 0,75 quilos de pargo/anzol/ hora, encontramos os seguintes resultados: esfôrço pesqueiro anual máximo $=63,4 \times 10^{5}$ anzóis/hora e captura anual máxima $=4.755$ toneladas de pargo.

A captura estimada para o nordeste brasileiro, no ano de 1970 , corresponde a 3.000 toneladas de pargo, um pouco superior àquela observada no ano anterior (tabela XVIII) . $\mathrm{Na}$ hipótese de um incremento constante das capturas, até o fim da década, teremos em

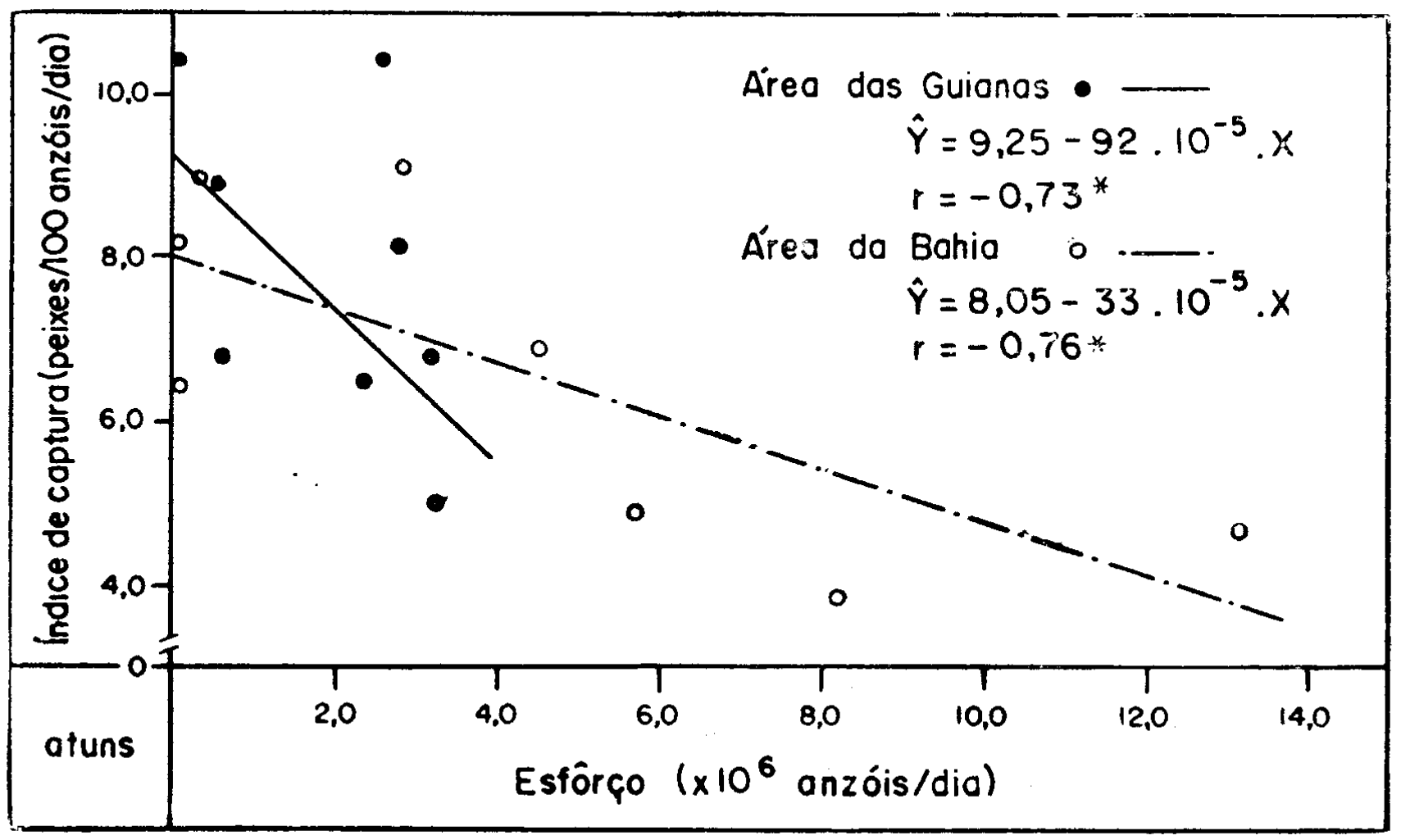

Figura 4 - Retas de regressão linear do índice de captura sôbre o esfôrço, e respectivas equações, relativas à captura de atuns, na área das Guianas e na áréa da Bahia. 


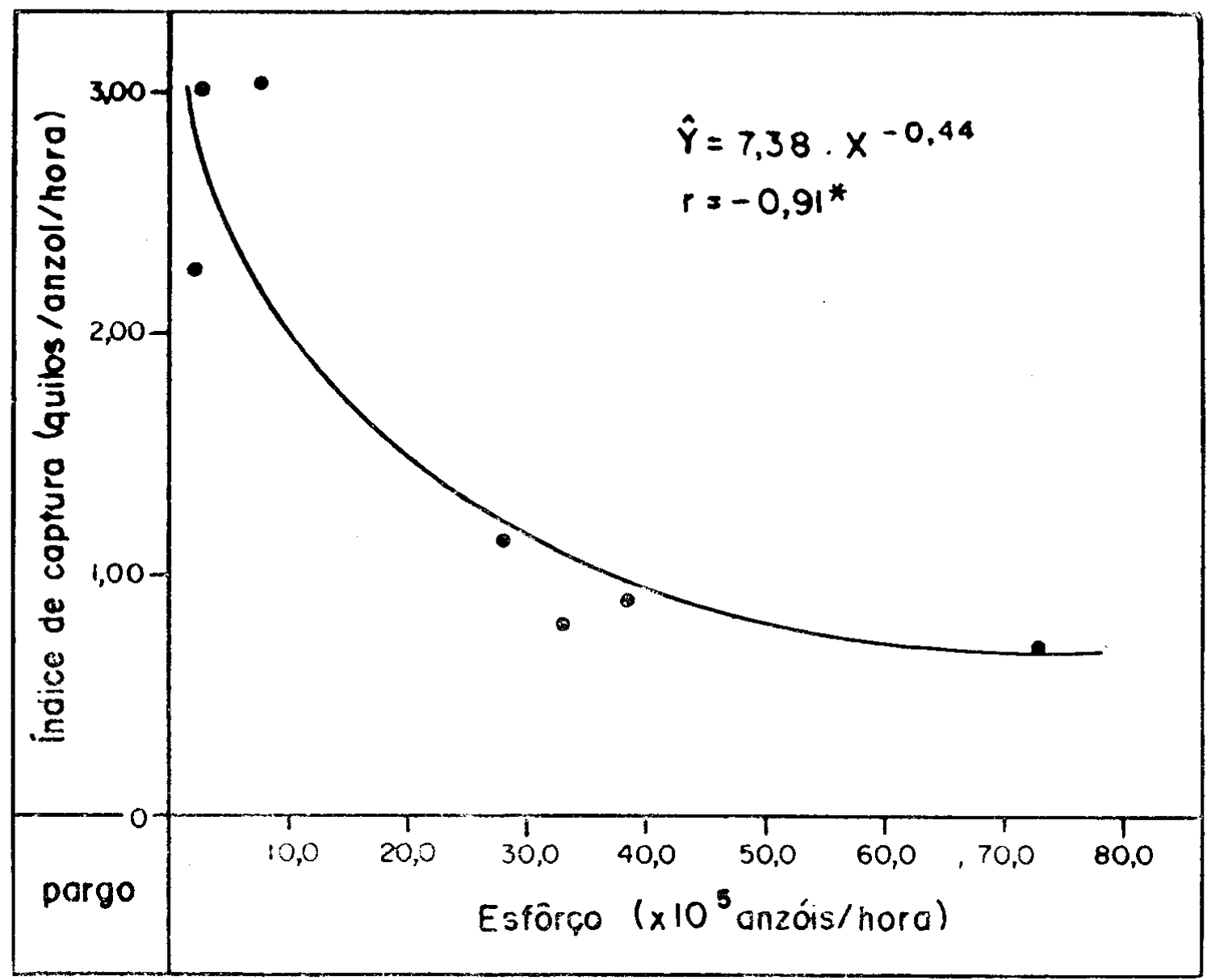

Figura 5 - Curva de regressāo exponencial do indice de captura sôbre o esfôrço, e respectiva equação, relativa à captura do pargo no nordeste brasileiro.

1975 a captura de 3.900 toneladas de pargo, 乞 em 1980 atingiremos a captura anual máxima, que corresponde a aproximadamente 4.750 toneladas. Na hipótese de um desenvolvimento acelerado das capturas, já em 1975 teremos atingido a captura anual máxima, não se esperando posteriores aumentos na produção de pargo, na área explorada pela frota regional.

Nas estimativas referentes à produção do pargo na área nordeste do Brasil, não consideramos a pequena zona de pesca localizada no Arquipélago dos Abrolhos e no Mar Nôvo, explorada por barcos baseados no pôrto do Rio de Janeiro (Estado da Guanabara). Tendo em vista êste fato, podemos admitir o total de 5.000 toneladas de pargo, como captura anual máxima para o nordeste brasileiro.

\section{Baleias}

A estimação das capturas de baleias foi feita com base na tendência de crescimento anual do número de baleias abatidas no nordeste brasileiro, durante os anos de 1962 a 1969 (tabela XIX) .

Fizemos o ajustamento dos dados ao modêlo do tipo $\mathrm{Y}=\mathrm{a}+\mathrm{bX}$, onde $\mathrm{Y}=$ número de baleias abatidas e $\mathrm{X}=$ ano - figura 6 .
A equação obtida foi a seguinte:

$$
\mathrm{Y}=121+68 . \mathrm{X}, \mathrm{r}=0,90^{*} \text {. }
$$

A captura estimada para o nordeste bra. sileiro, no ano de 1970 , corresponde a 750 baleias (aproximadamente 9.430 toneladas), pràticamente o mesmo número de abates verificados no ano anterior (tabela XX). Consideramos que o abate máximo anual de baleias no nordeste brasileiro corresponde a 1.000 indivíduos (aproximadamente 12.570 toneladas), total que deverá ser atingido a partir de 1975 , não se esperando posteriores aumentos nas capturas.

\section{Camarões marinhos}

De acôrdo com o Plano Indicativo Mundial da Organização de Alimentação e Agricultura das Nações Unidas, a estimativa da captura de pescado na área da plataforma con tinental, em frente ao Estado do Maranhão, situa-se em tôrno de $0,6 \mathrm{t} / \mathrm{km}^{2} /$ ano. Com base em Laevastu (1961), supõe-se que 13\% desta captura correspondem aos camarões. Considerando-se que a atual produção maranhense atinja, aproximadamente, 10.000 toneladas anuais, e que esta seja obtida na faixa. de pro. 


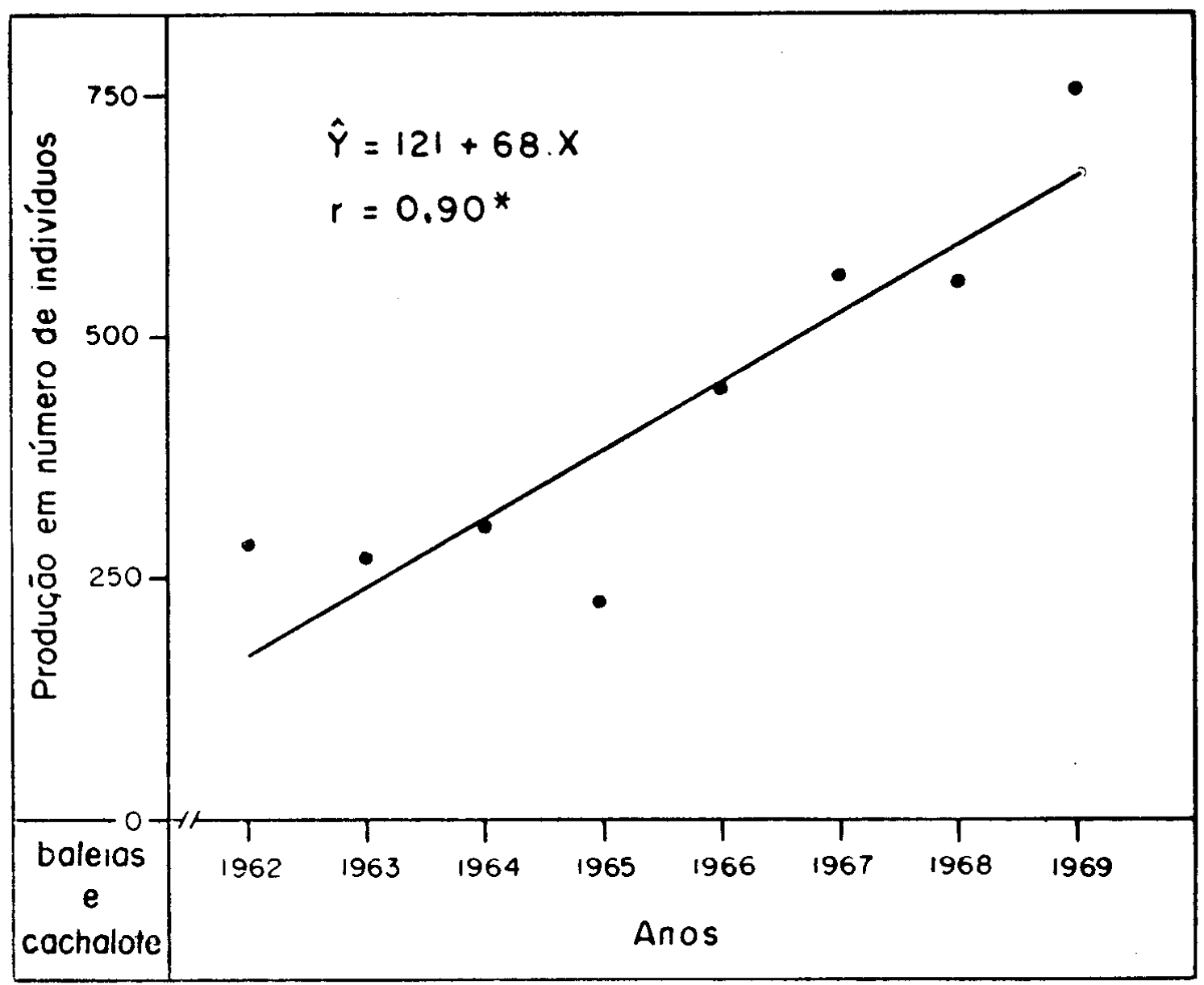

Figura 6 - Reta de regressão linear da produção sôbre os anos, e respectiva equação, relativa à captura de baleias (incluindo-se o cachalote) no nordeste brasileiro.

fundidade de 0 a 20 metros da plataforma continental, usaremos $o$ índice de produtividade de $0,28 \mathrm{t} / \mathrm{mi}^{2} /$ ano, para a faixa de profundidade de 20 a 100 metros (tabela III), esperando-se para esta última faixa uma produção anual de 4.650 toneladas de camarões.

Com base num trabalho de prospecção de camarões, levado a efeito na zona de influência do Rio São Francisco (Barros \& Jonsson, 1967), podemos esperar uma produção anual de 750 toneladas de camarões, obtida numa área correspondente a 176 milhas quadradas de fundos arrastáveis.

Dentro destas hipóteses, e considerando a possibilidade de implantação da pesca destas espécies em bases industriais, na região nordestina do Brasil, poderemos ter em 1975 a captura de 12.750 toneladas, e em 1980 a captura anual máxima, ou seja, 15.500 toneladas de camarões.

\section{Sururu}

Com base nas conclusões obtidas por Pereira-Barros (1969), sôbre a exploração do sururu na Lagoa Mundaú (Estado de Alagoas), é possível triplicar a produção dêste moluscos na região nordestina do Brasil, desde que se faça a introdução de substratos artificiais nos fundos lagunares, além de cultivos por estaqueamento e/ou cordas suspensas.

Dentro destas hipóteses, tendo-se em vista a produção regional do sururu no ano de 1965 (tabela XIV), poderemos atingir 7.500 toneladas em 1975 , alcançando-se 15.000 toneladas em 1980 , como metas para todo o nordeste brasileiro.

\section{Voador}

A captura regional do voador poderá ser grandemente ampliada, na hipótese de sua exploração em caráter industrial.

Mesmo nas atuais pescarias, a simples utilização do gêlo possibilitará que as capturas sejam triplicadas, em virtude de igual aumento no tempo de efetiva pesca, prolongando as viagens pela garantia da conservação do pescado a bordo.

A progressiva substituição dos botes a vela por botes motorizados, pescando em maior período do ano, com mais moderna aparelhagem e utilizando gêlo na conservação do pescado em porões isotérmicos, será o ca- 
minho para a implantação de modernas indústrias dedicadas à pesca do voador, que será feita por rêdes de cêrco flutuante operadas por barcos de grande porte.

Tendo-se em vista a produção regional do voador no ano de 1967 (tabela XII), poderemos atingir 2.500 toneladas em 1975 , alcançando-se 5.000 toneladas em 1980 , como metas iniciais do processo de industrialização dêste peixe no nordeste do Brasil.

\section{2 - Pesca artesanal}

\section{Organismos marinhos}

$\mathrm{Na}$ estimação das capturas artesanais de organismos marinhos, na região nordeste do Brasil, tomamos como base os dados apresentados na tabela XXV

De início, verificamos a tendência do crescimento da produção, e ajustamos os dados a um modêlo do tipo $\mathrm{Y}=\mathrm{a}+\mathrm{bX}$, onde $\mathrm{Y}=$ produção e $\mathrm{X}=$ ano (figura 7 ) .

A equação obtida foi a seguinte:

$$
\mathrm{Y}=15,11+2,48 . \mathrm{X}, \mathrm{r}=0,90^{*} \text {. }
$$

Desta maneira, obtivemos as estimativas da produção para os anos de 1970,1975 : 1980 , cujos respectivos valôres são os seguintes: $42.400,54.800$ e 67.200 toneladas de pescado.

Segundo os resultados alcançados pela Organização de Agricultura e Alimentação das Nações Unidas (Anonymous, 1961), num plano de motorização das embarcações a vela no Ceilão, a produtividade destas pode ser fàcilmente triplicada através do acoplamento de motores de pôpa, deixando inalteradas suas características básicas de construção. Paiva (1966) , com base na produção das embarcações sediadas na Praia de Mucuripe (Forta. leza - Estado do Ceará), encontrou para os botes motorizados uma captura anual média três vêzes superior à obtida pelas jangadas de piúba.

A motorização das embarcações a vela, aliada ao emprêgo de caixas isotérmicas com gêlo, para conservação de pescado a bordo, propiciará um aumento do tempo de efetiva pescaria e permitirá a exploração de áreas de pesca mais distantes.

Considerando a hipótese da progressiva $€$ uniforme motorização da frota pesqueira artesanal marinha do nordeste brasileiro até , ano de 1980 , com o emprêgo de aparelhos e métodos de pesca mais modernos, ao lado da utilização do gêlo na conservação do pescado a bordo, será possível triplicar a produção ar. tesanal marinha, sem maiores problemas.

Dentro desta hipótese, e excluindo as capturas de camarões e voador, que atualmen- te concorrem com cêrca de $30 \%$ do total da produção artesanal marinha (tais recursos entram para a pesca industrial), teremos em 1975 a produção artesanal de 115.200 toneladas de pescado, atingindo 141.600 toneladas em 1980 .

\section{Organismos estuarinos}

$\mathrm{Na}$ estimação das capturas artesanais de organismos estuarinos da região nordeste do Brasil, tomamos como base os dados apresentados na tabela XXV.

Verificamos a tendência de crescimento da produção, fazendo-se o ajustamento dos dados ao modêlo do tipo $\mathrm{Y}=\mathrm{a}+\mathrm{bX}$, onde $\mathrm{Y}=$ produção e $\mathrm{X}=$ ano (figura 8 )

A equação obtida foi a seguinte:

$$
\mathrm{Y}=5,71+1,69 . \mathrm{X}, \mathrm{r}=0,88^{*} \text {. }
$$

Desta maneira, calculamos as estimativas da produção para os anos de $1970,1975 \mathrm{e}$ 1980 , cujos respectivos valôres são os seguintes: $24.300,32.800$ e 39.500 toneladas de pescado.

Considerando as hipóteses do melhoramento do nível tecnológico dos métodos empregados na captura das espécies estuarinas e/ou da intensificação de cultivos, através da construção de viveiros em grande escala, cuj. rendimento por hectare/ano chega a alcançar 1.400 quilos no nordeste brasileiro (Menezes, 1964) , será possível triplicar a produção artesanal estuarina, sem maiores problemas.

Dentro destas hipóteses, e excluindo-se as capturas do sururu, que atualmente concorrem com cêrca de $18 \%$ do total da produção artesanal estuarina (tal recurso entra para a pesca industrial), teremos em 1975 a produção de 80.490 toneladas de pescado, atingindo-se 96.930 toneladas em 1980 .

\section{TAB E L A X X V}

Diaćos relativos à pesca ariesanal marinha e à pesca estuarina no nordeste brasileiro, durante os anos de 1960 a 1968

\begin{tabular}{c|c|c}
\hline \multirow{2}{*}{ Anos } & \multicolumn{2}{|c}{ Produção $\left(\times 10^{3} \mathrm{t}\right)$} \\
\cline { 3 - 3 } & pesca marinha & pesca estuarina \\
\hline 1960 & 17,7 & 9,0 \\
1961 & 20,0 & 11,1 \\
1962 & $57,3^{*}$ & $19,7 *$ \\
1963 & 30,3 & 10,6 \\
1964 & 21,3 & 9,7 \\
1965 & 31,8 & 13,7 \\
1966 & 33,4 & 20,3 \\
1967 & 39,8 & 20,3 \\
1968 & 31,7 & 21,9 \\
\hline
\end{tabular}

* Dado eliminado da análise.

Fontes: Serviço de Estatística da Produção - Ministério da Agricultura/Divisão de Recursos Pesqueiros - Superintendência do Desenvolvimento do Nordeste. 


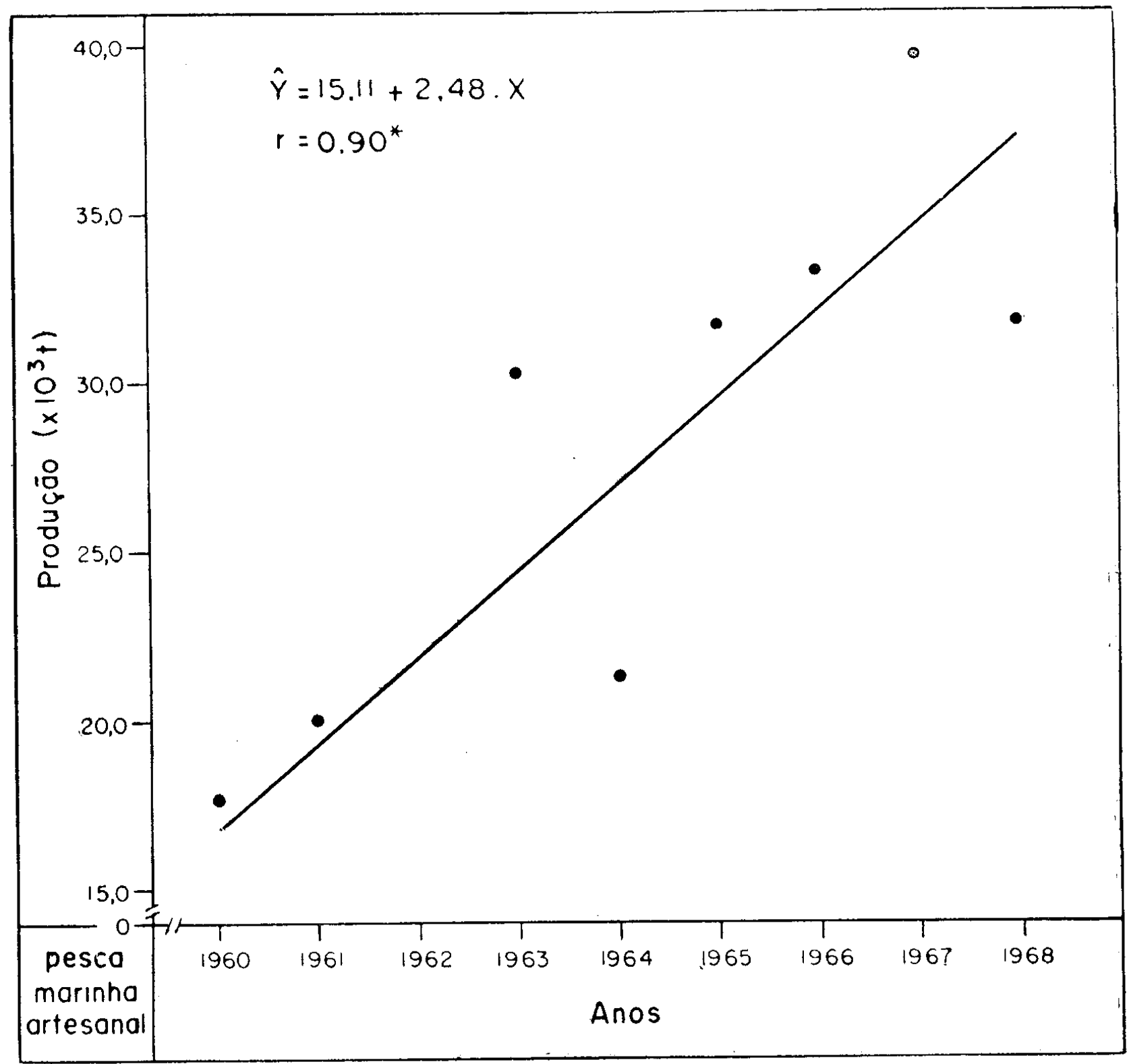

Figura 7 - Reta de regressão linear da produção sôbre os anos, e respectiva equação, relativa à captura de organismos marinhos pela pes ca artesanal no nordeste brasileiro.

Organismos de águas doces

$\mathrm{Na}$ estimação das capturas artesanais de organismos de águas interiores, na região nordeste do Brasil, tivemos que considerar a pesca nas águas represadas e nos rios.

A estimação das capturas das águas represadas foi feita a partir dos dados apresentados na tabela XXVI. Com o conhecimento da relação existente entre volume/área dos açudes, e aceitando-se que o volume total de água represada na região corresponde a cêrca de 20 x $10^{9}$ metros cúbicos, calculamos a área total coberta por reprêsas no nordeste brasileiro aproximadamente 415.800 hectares. A estimativa da produção de pescado em tais águas foi obtida através do produto - produtividade anual por hectare $\mathrm{x}$ área total em hectares.
Assim, a atual produção de pescado, nas reprêsas regionais, alcança o total aproximado de 22.000 toneladas/ano.

A produção anual de pescado nos rios do nordeste brasileiro foi calculada em 13.000 toneladas, com base em informações existentes na literatura e nos dados da produção de pescado em águas doces nos Estados do Maranhão e Piauí.

Dêste modo, estimamos para 1970 uma produção de pescado ao redor de 35.000 toneladas, para as águas interiores do nordeste brasileiro, não se esperando incremento significativo desta produção até o ano de 1980 , a não ser que se implante, dentro do âmbito regional, uma política de modernização dos métodos e aparelhos de pesca, juntamente com a tomada de uma série de medidas visando a 


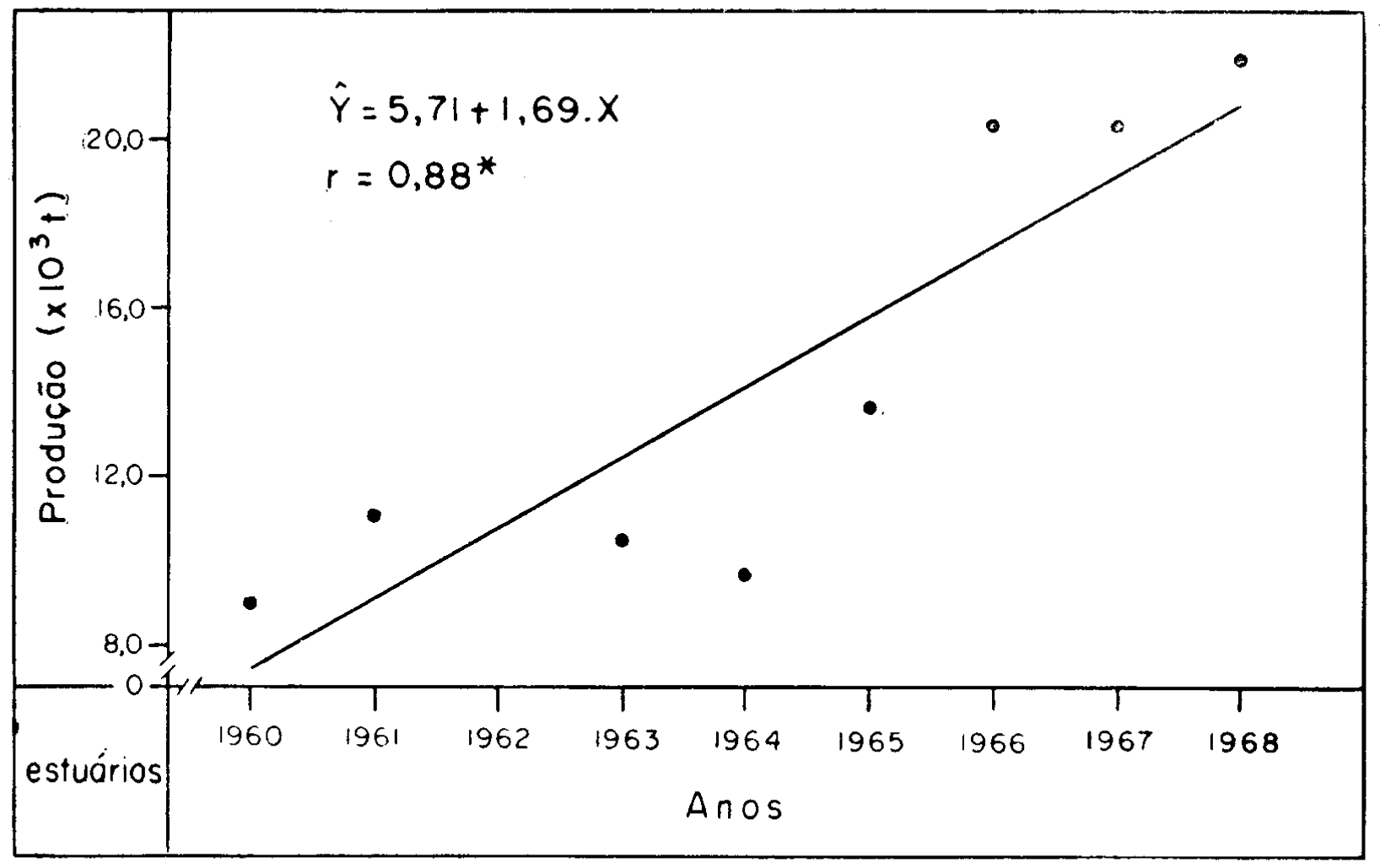

Figura 8 - Reta de regressão linear da produção sôbre os anos, e respectiva equação, relativa à captura de organismos estuarinos no nordeste brasileiro.

\section{T A B E L A X X V I}

Dados relativos a 11 açudes do nordeste brasileiro, necessários ao cálculo da produção de pescado nas águas represadas da região.

\begin{tabular}{|c|c|c|c|c|c|}
\hline Açudes & $\begin{array}{c}\text { Produção de } \\
\text { pescado } \\
(\mathrm{kg} / \text { ano })\end{array}$ & $\begin{array}{c}\text { Volume } \\
\text { d'água } \\
\left(\text { x } 10^{3} \mathrm{~m}^{3}\right)\end{array}$ & $\begin{array}{l}\text { Area } \\
\text { represada } \\
\text { (ha) }\end{array}$ & $\begin{array}{c}\text { Produtividade } \\
\text { anual } \\
\text { (kg/ha) }\end{array}$ & $\begin{array}{c}\text { Relação } \\
\text { volume } \\
\text { área }\end{array}$ \\
\hline $\begin{array}{l}\text { Aldeia } \\
\text { Bonfim } \\
\text { Riacho do Sangue } \\
\text { São Pedro } \\
\text { Salão } \\
\text { Tucunduba } \\
\text { Forquilha } \\
\text { Santa Maria } \\
\text { Bonito } \\
\text { Santa Cruz I } \\
\text { Soledade }\end{array}$ & $\begin{array}{r}1.000 \\
2.000 \\
75.400 \\
47.600 \\
5.200 \\
3.100 \\
60.100 \\
24.400 \\
24.200 \\
2.000 \\
10.000\end{array}$ & $\begin{array}{r}7.235 \\
3.821 \\
61.424 \\
19.259 \\
6.049 \\
42.000 \\
50.132 \\
8.997 \\
6.000 \\
776 \\
27.058\end{array}$ & $\begin{array}{r}218 \\
132 \\
919 \\
488 \\
129 \\
800 \\
1.000 \\
365 \\
222 \\
28 \\
539\end{array}$ & $\begin{array}{r}4,6 \\
15,2 \\
82,0 \\
97,5 \\
4,0,3 \\
3,9 \\
60,1 \\
66,8 \\
109,0 \\
71,4 \\
18,6\end{array}$ & $\begin{array}{l}33,2 \\
28,9 \\
66,8 \\
39,5 \\
46,9 \\
52,5 \\
50,1 \\
24,6 \\
27,0 \\
27,7 \\
50,2\end{array}$ \\
\hline Total & 255.000 & 232.751 & 4.840 & 52,7 & 48,1 \\
\hline
\end{tabular}

Fonte: Departamento Nacional de Obras Contra as Sêcas.

conservação dos recursos, e/ou um programa amplo de piscicultura intensiva.

De acôrdo com o Plano Indicativo Mundial da Organização de Alimentação e Agricultura das Nações Unidas, pode-se obter no Rio São Francisco uma produção de $20 \mathrm{~kg} / \mathrm{ha} /$ ano. Considerando-se a relativamente grande concentração de águas fluviais nas bacias dos Rios São Francisco, Parnaíba e dos rios maranhenses, e dentro das hipóteses acima referidas, a produção regional de pescado, nas águas interiores, poderá alcançar valôres superiores ao triplo das atuais capturas. Com o gradual estabelecimento de tais medidas, poderemos ter em 1975 a produção de 52.500 toneladas de pescado, atingindo-se 105.000 toneladas em 1980 .

\section{6 - SINTESE DAS ESTIMATIVAS}

Na tabela XXVII apresentamos a síntesa das estimativas da produção de pescado n) 
T A B E L A X X V I I

Síntese das estimativas da produção de pescado no nordeste brasileiro, até o ano de 1980 . Unidade $=1$ tonelada.

\begin{tabular}{|c|c|c|c|c|c|}
\hline \multirow{3}{*}{$\begin{array}{c}\text { Tipos de pesca } \\
\text { e de } \\
\text { pescado }\end{array}$} & \multicolumn{5}{|c|}{ Anos } \\
\hline & \multirow{2}{*}{1970} & \multicolumn{2}{|c|}{ hipotese pessimista } & \multicolumn{2}{|c|}{ hipótese otimista } \\
\hline & & 1975 & 1980 & 1975 & 1980 \\
\hline $\begin{array}{l}\text { Pesca industrial } \\
\text { - lagostas } \\
\text { - atuns } \\
\text { - pargo } \\
\text { - baleias } \\
\text { - camarões marinhos } \\
\text { - sururu } \\
\text { - voador }\end{array}$ & $\begin{array}{c}21.730 \\
8.000 \\
1.300 \\
3.000 \\
9.430 \\
* \\
* * \\
*\end{array}$ & $\begin{array}{r}26.770 \\
9.000 \\
1.300 \\
3.900 \\
12.570 \\
* \\
* * \\
*\end{array}$ & $\begin{array}{c}28.520 \\
9.900 \\
1.300 \\
4.750 \\
12.570 \\
* \\
* * \\
*\end{array}$ & $\begin{array}{r}64.970 \\
9.900 \\
15.000 \\
4.750 \\
12.570 \\
12.750 \\
7.500 \\
2.500\end{array}$ & $\begin{array}{r}92.720 \\
9.900 \\
30.000 \\
4.750 \\
12.570 \\
15.500 \\
15.000 \\
5.000\end{array}$ \\
\hline $\begin{array}{l}\text { Pesca artesanal } \\
\text { - organismos marinhos } \\
\text { - organismos estuarinos } \\
\text { - organismos de águas doces }\end{array}$ & $\begin{array}{r}101.700 \\
42.400 \\
24.300 \\
35.000\end{array}$ & $\begin{array}{r}122.600 \\
54.800 \\
32.800 \\
35.000\end{array}$ & $\begin{array}{r}141.700 \\
67.200 \\
39.500 \\
35.000\end{array}$ & $\begin{array}{r}248.190 \\
115.200 \\
80.490 \\
52.500\end{array}$ & $\begin{array}{r}3.13 .530 \\
141.600 \\
96 . \overline{930} \\
105.000\end{array}$ \\
\hline TOTAL & 123.430 & 119.370 & 170.220 & 313.160 & 436.250 \\
\hline
\end{tabular}

* Incluídos na pesca artesanal dos organismos marinhos.

* Incluido na pesca artesanal dos organismos estuarinos.

nordeste brasileiro, até o ano de 1980 , sob as hipóteses pessimista e otimista.

A hipótese pessimista corresponde ao simples aumento vegetativo das capturas, resultante da continuidade da atual estrutura de produção pesqueira na região. Dentro desta hipótese, a produção de pescado em 1980 será a seguinte: pesca industrial - 28.520 toneladas; pesca artesanal - 141.700 toneladas; total regional - 170.220 toneladas.

A hipótese otimista resulta da possibilidade de implantação de uma agressiva, ampla e profunda política de desenvolvimento pesqueiro, modificando a atual estrutura da produção de pescado na região. Dentro desta hipótese, a produção de pescado em 1980 poderá ser a seguinte: pesca industrial - 92.720 toneladas; pesca artesanal - 343.530 toneladas; total regional -436.250 toneladas.

O desenvolvimento pesqueiro do nordeste brasileiro é um problema sério, que desafia as agências governamentais, impondo a procura de soluções ousadas e transcendentais. Aliás, êste é o pensamento da Organização de Agricultura e Alimentação das Nações Unidas.

\section{7 - RECOMENDAÇÕES FINAIS}

1 - Considerando-se que a região nordeste do Brasil participa com $28,6 \%$ da produção nacional de pescado (período 1960/68), recomenda-se a adoção de uma política agressiva de desenvolvimento pesqueiro, à procura de soluções ousadas e transcendentais.

2 - No contexto regional, tendo-se em vista a produção de pescado e o seu crescimento, recomenda-se a concentração de esforços governamentais e empresariais nos Estados do Maranhão, Ceará e Bahia, objetivando a mais rápida promoção do desenvolvimento pesqueiro.

3 - Com relação à pesca das lagostas o do pargo, recomenda-se a continuidade e incremento das pesquisas em andamento na região, no que concerne à biologia e tecnologia pesqueiras, bem como aquelas relativas à tecnologia do pescado e aproveitamento de sub-produtos. Tais recursos se encontram sofrendo pesca industrial, gerando grandes desembarques anuais, sem que tenham sido definidas as respectivas capturas máximas sustentáveis.

4 - Estima-se que as capturas de atuns e peixes afins no Mar Territorial Brasileiro, nas chamadas áreas das Guianas e da Bahia, poderão atingir 30.000 toneladas anuais, caso se verifique real interêsse, público ou privado, pelo desenvolvimento da exploração atuneira no nordeste do Brasil. Sendo assim, recomenda-se especial e urgente atenção para a implantação de emprêsas dedicadas à pesca de atuns e peixes afins, com base em portos da região.

5 - Devemos considerar com seriedade 0 desenvolvimento da exploração camaroneira ao longo da costa do Estado do Maranhão, cujo grande obstáculo natural reside na introdução da pesca de arrasto. Idêntica preocupação deve ser tida na plataforma correspondente aos Estados de Alagoas, Sergipe e Bahia. Recomenda-se uma criteriosa prospecção pesqueira em tais áreas, com vistas à avaliação inicial do potencial de camarões e adequação da tecnologia da pesca.

6 - Considerando-se que o sururu é um importante recurso pesqueiro, principalmente para o Estado de Alagoas, recomenda-se o aumento de suas capturas através do uso de 
substratos artificiais nos fundos lagunares ou por cultivos, para suporte de sua industrialização, tendo-se em vista a produção de conservas finas.

7 - Sabendo-se que o voador ocorre com grande abundância desde o Estado de Pernambuco até o Estado do Maranhão, durante todo o ano, na distância máxima de 100 milhas da costa, recomenda-se a sua exploração industrial, com a utilização de modernos barcos de pesca, operando com rêdes de cêrco flutuante. Com o desenvolvimento das pesquisas sôbre a biologia e pesca do voador, bem como aquelas relativas ao seu aproveitamento industrial, será possível que êste peixe possa contribuir grandemente para o abastecimento do mercado interno regional, principalmente das camadas da população de mais baixas rendas, vivendo nas áreas interiores.

8 - Será possível triplicar a produção artesanal de pescado marinho da região, com a progressiva e uniforme motorização de sua frota pesqueira, que passará a operar com aparelhagem de pesca mais moderna e utilizando gêlo na conservação das capturas a bordo. Isto pressupõe um intenso programa de treinamento dos pescadores artesanais e sua organização junto a núcleos terrestres com instalações portuárias, frigoríficos e de fácil acesso aos mercados de consumo.

$9-$ Com relação às àguas estuarinas e com especial atenção para as taínhas, recomenda-se a melhoria dos aparelhos e métodos de pesca e/ou a intensificação dos cultivos, para que se possa triplicar a produção de pescado.

10 - A produção regional de pescado das águas interiores poderá alcançar valôres superiores ao triplo das atuais capturas, com $x$ modernização de métodos e aparelhos de pesca e/ou um programa amplo de piscicultura intensiva.

11 - Para melhor suporte da política de desenvolvimento pesqueiro regional, recomenda-se especial atenção para os atuais e futuros programas de investigação científica aplicada à pesca e aproveitamento dos seus produtos.

\section{8 - SUMMARY}

With this paper the authors present an assessment of the fishery resources potential of the brazilian northeast region, establishing the fishery production levels possible to be attained until 1980 . At the same time, development possibilities for the principal fishery resources of the brazilian northeast are studied.

The continental area corresponding to the States of Maranhão, Piauí, Ceará, Rio Grande do Norte, Paraíba, Pernambuco, Alagoas, Sergipe, and Bahia, together with the oceanic Federal Territory of Fernando de Noronha, are considered as the brazilian northeast. Although part of the State of Minas Gerais is included in the area called "Draught Polygonum", it is not considered in the present paper for the necessary statistical data is available only for the whole area of each federal political unit.

In this very large brazilian region, covering $1,615,004$ square kilometers, corresponding to $18.96 \%$ of the total area of Brazil, with a coast line of 3,671 kilometers, corresponding to $40.78 \%$ of the total coast line of Brazil, the large reentrances included, and finally, with a continental shelf measuring 58,808 square miles, fishery presents accentuated contrasts, from the most rudimental primitivism, to modern industrial activity.

According to the statistics, fishery production in the brazilian northeast reached a total of $1,032,075$ tons in the period from $1960-1968$, corresponding to $28.6 \%$ of the respective national production. Thus, the shars of the region in the national effort is signifficant for the development of fishery activities, resulting in a higher volume of catches.

Within the area, the States of Maranhão, Ceará, Paraíba, and Bahia, in decreasing importance order, present higher production. In the other States the fishery is less important, Piauí ranking in last place.

Taking as reference the year of 1960 (index $=100$ ), the national and regional production reached respectively the indexes of 178 and 159 in 1968. In this last year, the indexes superior to that registered for the nation, among the States of the region, corresponded to the States of Ceará, Bahia, and Piauí = Sergipe, in decreasing importance order; the State of Maranhão, although with an index superior to the regional, did not reach the national one; the indexes obtained by the other States show a slight fishery production increase.

Two natural groups predominate in the regional fishery landings - fishes and crustaceans, in decreasing weight order, the same also applying to Brazil in general; in the State of Paraiba mammals contribute with more than half of the total catch, while mollusks rank between fishes and crustaceans in the State of Alagoas.

On regional terms, during the period 1960-1968 the greatest part of the fishery production was marine, followed by inland and estuarine waters productions. Based on the available data, as well as in their own experience, the authors state that fishery production in the units of the region, according to its origin, follows the same pattern, except for the States of Piauí and Alagoas.

There are two different production systems in marine regional fishery: artisanal, 
along the whole coast, from simple subsistence activities, accomplished with the most rudimental technology, to those where the production is commercialized, under the lidership of small boat owners, these boats presenting better fishing characteristics, and operating with more modern gear; industrial, caracterized by the concentration of investiments on shore instalations, operating with larger boats provided with modern gear and fishing methods, for selective catches.

In the 1960-1968 period, in the artisanai fishery production, the principal species captured, in landing volume, were the following: crustaceans - shrimps; fishes catfishes, sharks, tarpon, king mackerel, croaker, weakfishes, grunt, sardines, spanish mackerel, and flyingfish. During the same period, in the industrial fishery production, the principal species captured, also in landing volume, were the following: crustaceans spiny lobsters; fishes - tunas and red snapper; mammals - whales.

In the regional estuarine fishery, very primitive fishing gears and methods predominate, for this is only a subsistence activity, with only a minor part of its production been commercialized.

During the 1960-1968 period, the principal estuarine species captured in the brazilian northeast, in landing volume, were the following: crustaceans - crabs and swimming crabs; mollusks - mussels; fishes - mullets.

Inland fishery in the brazilian northeast presents highly varied characteristics, being effected along rivers and reservoirs. Although generally a rudimental activity of simple subsistence, a relative progress is noted in the larger public reservoirs, not only regarding the fishing gears and methods, but also on the commercialization of the production.

During the 1960-1968 period, the principal species captured in inland fishery in the brazilian northeast, in landing volume, were the following: crustaceans - shrimps; fishes catfishes, characins, drums, sardines, and tigerfishes.

Basically, the fishing structure in the brazilian northeast is supported by two large groups: fishermen, and fishing crafts, both with low productivity. Besides certain industrial fisheries development tendencies, remains the one in which the growing fishery production results from the vegetative increase in number of fishermen and fishing crafts. Fisheries development in northeast Brazil is not an uniform and harmonious process, creating disparities within the region.

The authors present the following catch estimates for the brazilian northeast, for the industrial fishery.

1 - Spiny lobsters - The estimate catch for 1970 in the brazilian northeast corresponds to 8,000 tons, little superior to the one registered for the previous year. Considering that the fishing effort will be uniformely distributed in the fishing area, as a stock conservation measure, and, in the hypothesis of a constant catch increase until the end of this decade, there should be a capture of 9,000 tons in 1975 , and, in 1980 , the maximum annual yield should be reached, corresponding to 9,900 tons. In the case there is a faster catch development, by 1975 the maximum annual yield should be reached, no further increase in the spiny lobster production being expected.

2 - Tunas - In the hypothesis that the previous situation is not modyfied, the annual tuna catch off the brazilian northeast for the whole decade, until 1980 , can be estimated at 1,300 tons. However, in the case of modern tuna fishing enterprizes start operating, the situation will be highly modified.

In the last years, tuna catches in the areas of Guianas and Bahia, effected by foreign boats, according to F.A.O. data, averaged 15,000 tons a year. Thus, a further 15,000 tons remains available yearly, for the tuna fishing enterprizes that may come into operation in the brazilian northeast.

However, with the non concession of fishing licences to foreign boats in the present Brazilian Territorial Sea, the tuna fishing en. terprizes that may come to operate in the brazilian northeast may reach a catch of 15,000 tons in 1975, and 30,000 tons in 1980 .

3 - Red snapper - The estimated catch for the brazilian northeast in 1970 , corresponds to 3,000 tons, slightly superior to the one registered for the previous year. In the hypothesis of a constant increase in catches, until the end of the decade, there shall be a capture of 3,900 tons by 1975 , reaching the maximum annual yield of about 4,750 tons in 1980 . In the hypothesis of a faster catch development, by 1975 the maximum annual yield level shall be attained, no further increase in the red snapper production being expected in the area exploited by the regional fleet.

In the red snapper catch estimates for the brazilian northeast, the small fishing zones of Arquipélago dos Abrolhos and Mar Nôvo, both exploited by fishing boats from Rio de Janeiro (Guanabara State), were not considered. On account of that, a total of 5,000 red snapper tons can be admmited as the maximum annual yield for the brazillian northeast.

4 - Whales - The estimated catch for the brazilian northeast in 1970 , corresponds to 750 whales (approximately 9,430 tons), practically the same number of killings as the previous year. The maximum annual whale killings in the brazilian northeast is considered to be 1,000 individuals (aproximately 
12,570 tons), to be attained from 1975 cnward, no further capture increase being expected.

5 - Marine shrimps - Based on data obtained by F.A.O. and fishing prospection, a catch of 12,750 tons can be achieved by 1975 , if industrial shrimp fisheries are installed in the brazilian northeast, and, by 1980 , the maximum annual yield, of 15,500 tons.

6 - Mussels - Based on the 1955 regional production a catch estimate of 7,500 tons can be predicted for 1975 , if proper mussel culture is employed, reaching 15,000 tons in 1980 , for the whole brazilian northeast.

7 - Flyingfish - The regional catch of flyingfish could be highly increased, if industrialy exploited. Based on the 1967 regional production of this fish, a total of 2,500 tons can be attained by 1975 , reaching 5,000 tons by 1980 , as initial aims of the industrialization of this fish in the brazilian northeast.

The estimates for the artisanal fishery production in the brazilian northeast were effected for marine, estuarine, and inland waters.

1 - Marine fishery - According to the production increase verifyed on the data available, the following catch estimates were obtained for the years 1970,1975 , and 1980 respectively: $42,400,54,800$, and 67,200 tons, by the artisanal production system.

Considering the hypothesis that the fishing fleet be progressive and completely motorized, besides employing more modern fishing gears, it is possible to have by 1975 an artisanal fishing production of 115,200 tons, and 141,600 tons by 1980 , excluding th? catches of shrimps and flyingfish that comprise $30 \%$ of the artisanal marine production (these are included in the industrial fisheries).

2 - Estuarine fishery - According to the production increase verifyed in th? available data, the following catch esimates were obtained for the years 1970,1975 , and 1980 , respectively: $24,300,32,800$, an 1 39,500 tons.

Considering the hypothesis of technology level improvement of the methods employed in the catches of estuarine species and / or culture intensification, the production can reach the volume of 80,490 tons in 1975 , and 96,930 tons in 1980 , excluding the catches of mussels, that comprise $18 \%$ of the estuarine production (these are included in the industrial fishery).

3 - Inland fishery - Based on the literature and available data, it is possible to estimate a production of about 35,000 tons for the northeast brazilian inland waters in 1970 . No significative increase is expected until 1980 , unless a regional policy of modernization of fishing gears and methods is adopted, together with resources preservation steps and organized intensive culture program. If such measures are gradually adopted, it would be possible to have by 1975 a production of 52,500 tons, and 105,000 tons by 1980 .

Pessimistic and optimistic estimates are presented.

The pessimistic hypothesis corresponds to the vegetative catch increases, resulting from the continuation of the present fishing estructure in the region. In this case, the fishery production by 1980 will be the following: industrial fisheries $-28,520$ tons, artisanal fisheries - 141,700 tons, total production - 170,220 tons.

The optimistic hypothesis results from the possibility of the implantation of an aggressive, deep and ample fishery development policy, modifying the present fishery production structure of the region. In this case, the fishery production by 1980 could be the following: industrial fisheries - 92,720 tons, artisanal fisheries - 343,530 tons, total production - 436,250 tons.

Fisheries development in the brazilian northeast is a serious problem, challenging governamental agencies, and demanding the search of bold solutions.

These final recommendations are presented:

1 - Considering that fisheries production in the brazilian northeast represents $28.6 \%$ of the national production $(1960 / 1968$ period), an aggressive fishery policy, searching bold solutions is recommended.

2 - Having in view fisheries production and regional increase, governmental and industrial enterprize concentration is recommended in the States of Maranhão, Ceará, and Bahia, aiming faster promotion of fishery development.

3 - With reference to the spiny lobsters and red snapper fisheries, the continuity and increase of researches now carried out in the region, on biology and fishery technology, as well as those related to fish products and by-products is recommended. The two resources are being industrially exploited, with large annual landings, the maximum sustainable yield having not been defined yet.

4 - Although there is no great public or private interest in the fishery of tunas and related species in the brazilian northeast, it is estimated that the catches of these fishes in the Brazilian Territorial Sea, in the areas of Guianas and Bahia, could attain 30,000 tons per year. Thus, urgent and special attention is recommended for the implantation of tuna fishing enterprizes, located in the region.

5 - Shrimp exploitation along the coast of Maranhão State should be seriously considered, the only natural objection being the introduction of trawling net fisheries. Similar concern should be had for the continental 
shelf off Alagoas, Sergipe, and Bahia States. A criterious fishery prospection in these areas is recommended, in order to assess the initial shrimp potential and proper fishing technology to be applied.

6 - Considering that mussels are an important fishery resource, especially for the State of Alagoas, an increase in its production is recommended through the use of artificial substrates in suitable bottoms or through cultivation, in order to support its industrialization, aiming the cannery of fine foods.

7 - As it is known that the flyingfish occurs in large numbers throughout the year, at a maximum distance of 100 miles off shore from Pernambuco to Maranhão States, its industrial exploitation is recommended, utilizing modern fishing boats, and using purse seine nets. With research development, on its biology and fishery, as well as on its industrial utilization, this fish may possibly present a large contribution to the regional internal market, especially to the population with a lower financial income, living in interior areas of the region.

8 - With progressive and uniforme motorization of the fishing fleet, that would operate with more modern fishing gear and ice for the preservation of the captures on board, it will be possible to triplicate the artisanal marine fishing production of the region. This involves an intensive artisanal fishermen trainning programme and their organization into shore nucleus with docking and freezing facilities, as well as easy access to consumption markets.

9 - With relation to estuarine waters, and with special attention to mullets, fishing gears and methods improval is recommended, and/or culture intensification, in order to triplicate the production.

10 - Inland waters regional production can attain over three times the present one, with the modernization of fishing gears and methods, and/or with an ample programme of intensive culture.

11 - For a better support to the regional fisheries development policy, especial attention is recommended to the present and future scientific investigation programs, applied to fisheries and the utilization of its products.

\section{9 - BIBLIOGRAFIA CONSULTADA}

A bibliografia relativa aos assuntos tratados neste estudo é muito vasta e dispersa, abrangendo desde a simples divulgação científica até a pesquisa conduzida com os mais sofisticados métodos.

Entendem os autores que a bibliografia a seguir apresentada, e que realmente foi consultada, tem a maior importância, quando se estuda os aspectos ligados ao desenvolvimento da pesca na região nordeste do Brasil, abordados neste trabalho.

Outrossim, em virtude da impossibilidade da referência das fontes bibliográficas no próprio texto, pelo seu grande número, apenas algumas exceções foram admitidas, encontrando-se estas assinaladas com asterisco $\left(^{*}\right)$, na presente bibliografia.

Aguirre, A. C. - $1954-$ A pesca e a caça no alto São Francisco. Ministério da Agricultura, Divisão de Caça e Pesca, 28 pp., 9 figs., Rio de Janeiro.

Aguirre, A. C. - 1956 - Relatório sôbre a pesca no baixo São Francisco. Ministério da Agricultura, Divisão de Caça e Pesca, 12 pp. datilografadas, Rio de Janeiro.

Alarcão, J. d' - 1953 - Present status and prospective of the fishery industry in Latin America. United Nations, Food and Agriculture Organization, 31 + 31 pp., Roma.

Almeida, N. U.' M. - 1965 - Estudos preliminares sôbre a primeira maturação sexual, época de desova e "sex-ratio" do pargo (Lutianus aya) no Nordeste. Bol. Est. Pesca, Recife, 5 (1): 33-42, 4 figs.

Almeida, N. U. M. - 1966 - Estudos sôbre a maturidade do peixe voador (Hirundichtys affinis Gunther) na costa nordestina do Brasil. Bol. Est. Pesca, Recife, 6 (3) : 31-41, 3 figs.

Anônimo - 1937 - A pesca do voador. Voz do Mar, Rio de Janeiro, (147) : 32 .

Anônimo - 1961 - Utilização de tilápia como isca de espinhel para tunideos e afins. Bol. Est. Pesca, Recife, 1 (1) : 13-17.

Anônimo - 1963 - Promoção do artesanato da pesca. Bol. Est. Pesca, Recife, 3 (8) : 3-7.

Anônimo - $1967-$ Pescarias experimentais do peixe voador nos Estados do Rio Grande do Norte, Paraíba e Pernambuco. Informaçóes Pesqueiras, Recife, 1 (1) : 3-4, 1 fig.

Anonymous - 1958 - Cooperatives as a means of fostering fishery development. FAO Fish. Papers, Roma, (9) : 1-6.

Anonymous - $1958-$ Role of government in fisheries development. FAO Fish. Papers, Roma, (11) : $1-8$.

Anonymous - 1958 - World fisheries: general trends and outlook with examples from selected countries. FAO Fish. Papers, Roma, (12) : 1-29.

* Anonymous - 1961 - Age-Old Patterns, Low Incomes Yield to the "Drive" of New Engines. Freedom from Hunger Campaign News, Roma, April: 6-7, [3 figs.].

Anonymous - 1967 - Marine fishing in northeast Brazil. U.S. Fish. Wildl. Serv., Foreign Fish. Leafl., Washington, (69) : 1-25.

Anonymous - 1970 - Brazil sets catch target at $2 \mathrm{~m}$. tons by 1972 . Fish. News Intern., London, 10 (4): $52-54$, [4 figs.]

Araújo. A. A. - 1968 - A Baleia na Paraiba. Equipesca Jornal, Campinas, (21) : [4-5] , 3 figs.

Azevedo, P. - $1938-\mathrm{Da}$ Biologia dos Peixes Nordestinos (Fragmento Biocenótico). In Livro Jubilar do Professor Lauro Travassos, pp. 51-60, Rio de Janeiro.

Azevedo, P. - 1938 - Conferencia feita no Rotary Club de Fortaleza. Bol. Insp. Fed. Obr. Contr. Sêc., Fortaleza, 4 (2) : 53-58.

Azevedo, P. - 1938 - O cascudo dos açudes nordestinos "Plecostomus plecostomus". Arq. Inst. Biol., São Paulo, 9 (20) : 211-224, 14 figs., est. 24. Azevedo, P.; Dias, M. V. \& Vieira, B. B. 1938 - Biologia do saguirú (Characidae, Curimatinae). Mem. Inst. Osw. Cruz, Rio de Janeiro, 33 (4) : 481-553, $4+12$ figs., 3 ests.

Azevedo, P. \& Gomes, A. L. - 1942 - Contribuição ao estudo da biologia da Traíra, Hoplias malabarica (Bloch, 1794) . Bol. Ind. Anim., São Paulo, 5 (4) : 15-64, $4+7+44$ figs.

Azevedo, P. \& Vieira, B. B. - 1938 - Contribuição para o Catálogo Biológico dos peixes fluviais do Nordeste do Brasil. Bol. Insp. Fed. Obr. Contr. Sêc., Rio de Janeiro, 9 (1): 82-92, [3 ests.]. 
Azevedo, P. \& Vieira, B. B. - 1938 - Contribuição para o Catálogo Biológico dos peixes fluviais do Nordeste do Brasil. II . Piábas (Characidae, Tetragonopterinae) . Bol. Insp. Fed. Obr. Contr. Sêc., Rio de Janeiro, 10 (1) : 71-75, [3 ests.].

Azevedo, P. \& Vieira, B. B. - 1939 - Contribuição para o Catálogo Biológico dos peixes fluviais do Nordeste do Brasil. III . Saguirú, Curimatus elegans Steindachner (Characidae, Curimatinae). Bol. Insp. Fed. Obr. Contr. Sêc., Rio de Janeiro, 11 (2): 181-184, 1 est.

Azevedo, P. \& Vieira, B. B. - 1940 - Realizações da Comissão Técnica de Piscicultura - 1940 . Bol. Insp. Fed. Obr. Contr. Sêc., Rio de Janeiro, 13 (2) : 113-124, [28 ests.].

Banco Interamericano de Desarrollo - 1971 Orientaciones de política relacionadas con la promoción del desarrollo pesquero en los países miembros del BID. CARPAS/Doc. Inf, , Rio de Janeiro, 5 (5) : 1-15 .

Barros, A. C - 1963 - A pesca no Território de Fernando de Noronha. Bol. Est. Pesca, Recife, 3 (13) : 13-15.

Barros, A. C. - 1965 - Alguns aspectos sôbre a biologia e pesca da albacora branca (Thunnus alalunga Gmelin) no Atlântico Tropical. Bol. Est. Pesca, Recife, 5 (5) : 12-27, 7 figs., 17 mapas.

Barros, A. C. \& Fonsêca, J. B. G. - $1965-$ Análise das pescarias de atuns e espécies correlatas no Atlântico Tropical no ano de 1963 . Bol. Est. Pesca, Recife, 5 (2) : 23-32

* Barros, A. C. \& Jonsson, S. - 1967 - Prospecção de camarões na região estuarina do Rio São Francisco. Bol. Est. Pesca, Recife, 7 (2) : 9-29, 5 figs., 4 mapas.

Barros, A. C. \& Morais, S. B. - 1968 - Prospecção de áreas de pesca do peixe-voador (Cypserulus cyanopterus, Valenciennes, 1846) ao longo do litoral dos Estados de Pernambuco e Paraiba. Bol. Est. Pesca, Recife, 8 (3) : 9-16, 1 fig., 1 mapa.

Barroso, L. - 1967 - Biologia e pesca do peixe-voador (Hirundicthys affinis Gunther) no Estado do Rio Grande do Norte. Bol. Est. Pesca, Recife, 7 (1) : 9-37, 11 figs

Beardsley Jr., G. L. - 1970 - The Atlantic albacore fishery. Comm. Fish. Rev., Washington, 32 (6) : 41-45, 2 figs.

Beatty, S. A. - 1961 - Brazilian fishing. In Atlantic Ocean Fisheries, Fishing News (Books) Ltd., pp. 205-212, [2 ests.], London.

Beerer, C. - 1955 - Economic influence on design of fishing craft, FAO Fish. Papers, Roma, (3) : 1-8

Benevides, C. A. F. et al. - $1964-$ Politica de desenvolvimento das pescas do Estado do Ceará. Secretaria da Agricultura, Indústria e Comércio, II +. $26 \mathrm{pp}$., Fortaleza.

Borges, G. A. - 1965 - Produção de pescado em Caiçara, $R$. G. do Norte, setembro de 1964 a agôsto de 1965 . Bol. Est. Pesca, Recife, 5 (6) : 17-27, 2 figs.

Boschi, E. E. - 1963 - Los Camarones Comerciales de la Familia Penaeidae de la Costa Atlántica de América del Sur. Bol. Inst. Biol. Mar, , Mar del Plata, (3) : 1-39, 11 figs.

Boschi, E. E. - 1969 - Biología y evaluación de los recursos camaroneros en el área de la "CARPAS". CARPAS/Doc. T'éc., Rio de Janeiro, (13) : 1-17, 1 mapa.

Braga, I. B. - 1970 - Estatisticas das Pescas Marítimas do Estado do Ceará. Ano de 1969 . Ceará Pescas S. A. - Companhia de Desenvolvimento (CEPESCA), 54 pp., Fortaleza.

Braga, R. A. - 1951 - Peixamentos de açudes no nordeste do Brasil. Chácaras e Quint., São Paulo, 84 (5) : 567-568, [3 figs.].
Braga, R. A. - 1964 - Disponibilidade de peixes em poços do Rio São Francisco, Brasil. Bol. Soc. Cear. Agron., Fortaleza, 5: 77-86, 2 figs.

Buesa Más, R. J. \& Paiva, M. P. - $1969-$ Pesquerias de la langosta Panulirus argus (Latreille) en el Brasil y en Cuba. Arq. Est. Biol. Mar. Univ. Fed. Ceará, Fortaleza, 9 (1) : 77-81, 2 figs.

Buesa Más, R. J.; Paiva, M. P. \& Costa, R. S. - 1968 - Comportamiento biológico de la langosta "Panulirus argus" (Latreille) en el Brasil y en Cuba. Rev. Bras. Biol., Rio de Janeiro, 28 (1) : $61-70,1$ fig.

Bullis, H. R. \& Thompson, J. R. - $1959-$ Shrimp exploration by the $R / V$ Oregon along the northeast coast of South America. Comm. Fish. Rev., Washington, 21 (11) : 1-9, 7 figs.

Burgess, J. - 1971 - Longliners have wide choice of equipment. Fish. News Intern., London, 10 (4) : 52-54, [4 figs.].

Câmara Néto, C. - 1966 - Algumas algas de provável aproveitamento industrial no litoral do Rio Grande do Norte. Bol. Inst. Biol. Mar. Univ. Fed. $R$. G. Norte, Natal, $3: 53-57$

Carpenter, J. S. - $1965-$ A Review of the Gulf of Mexico Red Snapper Fishery. Circ. Bur. Comm. Fish., Washington, (208): Iv + 35 pp., 26 figs.

Carvalho, V. A. - 1954 - Sôbre os viveiros de peixe do Recife. Ministério da Agricultura, Divisão de Caça e Pesca, 14 pp., 13 figs., Rio de Janeiro.

Cascudo, L. C. - 1957 - Jangada - uma pesquisa etnográfica. Ministério de Educação e Cultura, 183 pp., [21 ests.], Rio de Janeiro.

Cavalcanti, L. B. et al. - 1967 - Shelf off Alagoas and Sergipe (Northeastern Brazil). Trab-s. Inst. Oceanogr. Univ. Fed. Pe., Recife, 7/8: 137-149, 7 figs.

Coêlho, P. A. - 1962 - Súmula de observações sôbre a lagosta comum. Bol. Est. Pesca, Recife, 2
(5) : 3-11.

Coêlho, P. A. - 1963 - Crescimento da lagosta comum Panulirus argus (Latreille) no litoral do Estado de Pernambuco - Brasil. Trabs. I.O. - U.R Recife, 3 (1) : 69-73, 3 figs.

Coêlho, P. A. - 1963 - Observações preliminares sôbre a biologia e pesca dos camarões do gênero Macrobrachium Bate, 1868 (Decapoda, PalaeInst. Oceanogr., Recife, 3 (1): 75-81.

Coêlho, P. A. - 1965 - Algumas observações sôbre a biologia e a pesca dos siris (Crustacea, Decapoda, Portunidae) em Pernambuco. Ciência $e$ Cultura, São Paulo, 17 : 310 .

Coêlho, P. A. - 1967 - Estudo ecológico da Lagoa do Olho d'Agua, Pernambuco, com especial referência aos crustáceos decápodos. Trab-s. Inst. Oceanogr. Univ. Fed. Pe., Recife, 7/8: 51-69, 4 figs.

Coêlho, P. A. - 1967 - Os crustáceos decápodos de alguns manguezais pernambucanos. Trab-s. Inst. Oceanogr. Univ. Fed. Pe., Recife, $7 / 8:$ : 71-89,
3 figs.

Coêlho, P. A. et al. - 1963 - Nota sôbre a reprodução das lagostas Panulirus argus (Latreille) e $P$. laevicauda (Latreille) (Decapoda: Palinuridae) no litoral do Estado de Pernambuco. Trabs. I.O - U.R., Recife, 3 (1) : 61-67, 6 figs.

Coêlho, P. A. \& Ramos, M. A. - 1968 - Contribución al conocimiento de los camarones comerciales en el norte y nordeste del Brasil. CARPAS/. Doc. Téc., Rio de Janeiro, 4 (10) : $1-4$.

Coêlho, R. R. - $1963-$ Aspectos bio-tecnológicos da pesca marinha no Maranhão, Piauí e Ceará. Bol. Est. Pesca, Recife, 3 (6) : 8-18, 6 figs.

Coêlho, R. R. - 1966 - Análise preliminar sôbre a pesca do pargo, Lutjanus aya (Block, 1795) na 
costa do nordeste brasileiro. Res. VII Reun. Nac.

Téc. Pesq. Pesca Mar., Santos, (51): 1

Cope, C. E. - 1966 - Equipamentos e métodos empregados na pesca de lagosta. Bol. Est. Pesca, Recife, 6 (3) : 9-29, 13 figs.

Corcoran, E. F. \& Hahnken, C. V. W. - 1969 - Productivity of the Tropical Atlantic Ocean. Proc. Simp. Ocean. Fish. Res. Trop. Atlant., Paris: $57-67,10$ figs.

Costa, R. S. - 1966 - Dados sóbre a frota lagosteira do Ceará. Bol. Est. Biol. Mar. Univ. Fed. Ceará, Fortaleza, (13): 1-14, 2 figs.

Costa, R. S. - 1968 - Estudo preliminar sôbre a biologia e a pesca do caranguejo Carpilius coraliinus (Herbsî́) no Estado do Ceará. Arq. Est. Biol. Mar. Univ. Fed. Ceará, Fortaleza, \& (2): 211-219, 6 figs.

Costa, R. S. - 1969 - Dados sôbre a frota lagosteira do Ceará, nos anos de 1966 a 1968. Arq. Ciên. Mar, Fortaleza. 9 (2) : 119-126, 2 figs.

Costa, R. S. \& Albuquerque, J. J. L. - $1966-$ Experimentacão de covos para a captura de lagostas no Ceará. Bol. Est. Biol. Mar. Univ. Fed. Ceará, Fortaleza, (14) : 1-7, $1 \mathrm{fig}$.

Costa, R. S. \& Bezerra, R. C. F. - $1970-$ Influência de métodos de pesca sôbre a eficiência dos covos, na captura de lagostas no Ceará. Arq. Ciên. Mar, Fortaleza, 10 (2) : 127-130

Costa, R. S. \& Paiva, M. P. - 1963 - Notas sôbre a pesca da cavala e da serra no Ceará - Dados de 1962. Arq. Est. Biol. Mar. Univ. Ceará, Fortaleza, 3 (1) : $17-26,4$ figs.

Costa, R. S. \& Paiva, M. P. - 1964 - Notas sôbre a pesca da cavala e da serra no Ceará - Dados de 1963. Arq. Est. Biol. Mar. Univ. Ceará, Fortaleza, 4 (2) : 71-81, 5 figs.

Costa, R. S. \& Paiva, M. P. - 1965 - Notas sôbre a pesca da cavala e da serra no Ceará Dados de 1964 . Arq. Est. Biol. Mar. Univ. Ceará, Fortaleza, 5 (2) : 93-101, 5 figs.

Costa, R. S. \& Paiva, M. P. - 1966 - Notas sôbre a pesca da cavala e da serra no Ceará Dados de 1965 . Arq. Est. Biol. Mar. Univ. Fed. Ceará, Fortaleza, 6 (2) : 195-204, 4 figs.

Costa, R. S. \& Paiva, M. P. - 1967 - Notas sôbre a pesca da cavala e da serra no Ceará - Dados de 1966. Arq. Est. Biol. Mar. Univ. Fed. Ceará, Fortaleza, 7 (2) : 181-190, 4 figs.

Costa, R. S. \& Paiva, M. P. - 1968 - Notas sôbre a pesca da cavala e da serra no Ceará Dados de 1967 . Arq. Est. Biol. Mar. Univ. Fed. Ceará, Fortaleza, 8 (2) : 125-131, 3 figs.

Costa, R. S. \& Paiva, M. P. - 1969 - Notas sôbre a pesca da cavala e da serra no Ceará - Dados de 1968. Arq. Ciên. Mar, Forialeza, 9 (1): 89-95 3 figs.

Costa, R. S. \& Paiva, M. P. - 1970 - Notas sôbre a pesca da cavala e da serra no Ceará - Dados de 1969. Arq. Ciên. Mar, Fortaleza, 10 (2): $147-152,3$ figs.

Coutinho, P. N. - 1970 - Sedimentation at the mouth of the São Francisco River (Brazil). Trab-s. Oceanogr-s. Univ. Fed. Pe., Recife, 9/11 : 41-49, 3 figs.

Coutinho, P. N. \& Morais, J. O. - 1970 - Distribución de los sedimentos en la plataforma continental norte y nordeste del Brasil. Arq. Ciên. Mar, Fortaleza, 10 (1): 79-90, 3 figs.

Cruz, J. F. - 1965 - Sôbre a biologia pesqueira do voador, Hirundicthys affinis (Günter 1866), no Nordeste do Brasil. Bol. Inst. Biol. Mar. Univ. Fed. $R . G$. Norte, Natal, $2: 19-31,6$ figs.

Cruz, J. F. - 1965 - Contribuição ao estudo da biologia pesqueira da albacora Thunnus atlanticus (Lesson), no Nordeste do Brasil. Bol. Inst. Biol. Mar. Univ. Fed. R. G. Norte, Natal, 2 : 33-40, 3 figs.
Cruz, J. F. - 1966 - Análises das pescarias de lagostas no Estado do Rio Grande do Norte. Bol. Inst. Biol. Mar. Univ. Fed. R. G. Norte, Natal, $3: 1-19,4$ figs.

Cruz, J. F. - 1967 - Análises da pesca da albacora Thunnus atlanticus (Lesson), no Estado do Rio Grande do Norte. Bol. Inst. Biol. Mar. Univ. Fed. $R$. G. Norte, Natal, 4: 43-55, 3 figs.

Cruz, J. F. - 1970 - Boletim Informativo da Produção Pesqueira do Estado do Rio Grande do Norte. Universidade Federal do Rio Grande do Norte, Instituto de Biologia Marinha, 48 pp., 1 fig., Natal.

Cruz, J. F. \& Paiva, M. P. - 1964 - Sôbre a biologia pesqueira da albacora, Thunnus atlanticus (Lesson), no nordeste do Brasil. Bol. Inst. Biol. Mar. Univ. R. G. Norte, Natal, 1:1-15, 9 figs.

Cruz, J. F. \& Paiva, M. P. - 1964 - Notas sóbre a alimentação de Thunnus atlanticus (Lesson), ao largo do nordeste brasileiro. Bol. Inst. Biol. Mar. Univ. $R$. G. Norte, Natal, $1: 33-39$

Diretoria de Hidrografia e Navegação - 1968 - XXXV Comissão Oceanográfica. "Operação Norte/Nordeste I" NOc "Almirante Saldanha". DG $26-X I$, VIII + 530 pp., 269 figs., Rio de Janeiro.

Duque, J. G. - 1953 - Solo e Agua no Poligono das Sêcas. Serviço Agro-Industrial, 306 pp., [75 ests.], 12 tabelas em páginas não numeradas, Fortaleza.

Emilsson, I. - 1959 - Alguns aspectos físicos e químicos das águas brasileiras. Ciência e Cultura, São Paulo, 11 (2) : 44-54, 6 figs.

* FAO - 1968 - Plan Indicativo Mundial. Recursos Pesqueros y Prospección para su Desarrollo - América del Sur. CARPAS/DOc. Inf., Rio de Janeiro, 4 (9): $1-26,10$ tabelas.

FAO - 1968 - La situación de los efectivos (stocks) de atunes en los Oceanos Atlántico e Indico. CARPAS/DOC. Téc., Rio de Janeiro, 4 (3): 1-3

FAO - 1968 - Report of the meeting of a group of experts on tuna stock assessment. FAO Fish. Rep., Roma, (61): I-VI + 1-45, 20 figs.

Fausto Filho, J. - 1965 - Dados sôbre a pesca de camarão em Mucuripe. Col . Est. Pesca, Fortaleza, $1: 33-36$.

Fausto Filho, J. - 1968 - General considerations on the peneids of north and northeast of Brazil. Arq. Est. Biol. Mar. Univ. Fed. Ceará, Fortaleza, 8 (1) : 69-73

Fernandes, L. M. B. - 1969 - Sóbre a alimentação da lagosta Panulirus argus (Latr.) 1804 Crustacea Reptantia. I - Estágio Juvenil. Bol. Est. Pesca, Recife, 9 (1): 21-33, 2 figs.

Figueiredo, L. - 1937 - A pesca do tubarāo no Maranhão. Voz do Mar, Rio de Janeiro, 16 (146) : $319-321,3$ figs.

Fonsêca, J. B. G. - 1962 - Observações sôbre o emprègo do espinhel (long-line) na captura de tunídeos. Bol. Est. Pesca, Recife, 2 (1): 13-16, 5 figs.

Fonsèca, J. B. G. - 1963 - Pescarias de atuns e espécies afins em águas costeiras. Bol. Est. Pesca, Recife, 3 (2) : 17-18.

Fonsêca, J. B. G. \& Barros, A. C. - $1963-$ Sòbre as pescarias de atuns e afins e suas áreas de ocorrência no Atlântico Tropical no biênio 1961-1962 . Bol. Est. Pesca, Recife, 3 (7) : 18-22

Fonsêca, J. B. G. et al. - 1968 - Relatório preliminar sôbre o emprêgo de atração luminosa como método auxiliar na captura de peixes marinhos. Bol. Est. Pesca, Recife, 8 (2) : 23-38, 7 figs.

Fonteles Filho, A. A. - 1968 - Sôbre a captura e abundância da cavala e da serra nos pesqueiros do Estado do Ceará. Arq. Est. Biol. Mar. Univ. Fed. Ceará, Fortaleza, 8 (2) : 133-137. 
Fonteles Filho, A. A. - 1969 - Estudo preliminar sôbre a pesca do pargo, Lutjanus purpureus Poey, no nordeste brasileiro. Arq. Ciên. Mar, Fortaleza, 9 (1) : 83-88, 1 fig.

Fonteles Filho, A. A - - 1970 - Estudo sôbre a biologia da pesca do pargo, Lutjanus purpureus Poey, no nordeste brasileiro. Arq. Ciên. Mar, Fortaleza, 10 (1) : 73-78, 1 fig.

Fonteles Filho, A. A. - MS - Importância do pargo como recurso pesqueiro do nordesie bra. sileiro.

Fonteles Filho, A. A. \& Kurisaka, S. - $1970-$ Some oceanographic conditions related to the $\mathrm{Ca}$ ribbean red snapper fishery, off the Northeast Brazil. Arq. Ciên. Mar, Fortaleza, 10 (2): 177-180; 1 fig:

Fontenele, O - 1960 - Aumento da produção pesquetra dos açudes pela melhoria da aparelhagem de pesca. Bol. Soc. Cear. Agron., Fortaleza, 1 : 77:-82.

Fontenele, O. - 1962 - Custo operacional da pesca com redes de "nylon" no Acude' Araras e cálculo: da produção minima econômica . Bol. Serv. Piscic., Fortaleza, (1) : 1-8; 2 figs

Fontenele, $Q .1965-$ Resultados da aclimação da pescada do Piauí, "Plagioscion squamosissimus". (Heckel); procedente da bacia do Parnaiba, nos açudes do "Poligono das Sêcas. Bot. DNOCS, Sér. Fom. Prod, Recife, 23 (13/14): 351-361, 5 fig's.

Fontenele, O. - 1967 - Diretrizes adotadas pelo Departamento Nacional de Obras Contra as Sêcas para o aproveitamento dos açudes na produção de pescado. Circ. Inst. Biol. Tecn. Pesq., Fortaleza, (1) : $1-8$.

Fontenele, $\mathrm{O}_{2}-1968$ - Análise sumária dos primeiros nove anos de pesca comercial no acude Araras. Circ. Inst. Biol. Tecn. Pesq., Fortaleza, (2) : $1-16,3$ figs

Fontenele, O. - 1969 - Comentário sôbre vinte e sete anos de pesca comercial no açude Lima Campos Bol. DNOCS, Sér. Fom: Prod, Fortaleza, 27 $(2 / 4): 9-24,3$ figs.

Fourmanoir, P. - 1968 - La pêche au pagre, Lutjanus aya, au large de la Guayane et du Brésil. La Pêche Maritime, Paris, (1080) : 4 pp., 8. figs.

Furtado, E. - 1968 - Alguns dados sóbile a alimentação de jovens do gềnero Mugil Linnaeus, no Esstado do Ceará. Arq. Est. Biol. Mar. Univ. Fed. Ceará, For taleza, 8 (2) : 173-176

Gonçalves, A. - 1927 - Breve noticia sôbre a tainha. Voz do Mar, Rio de Janeiro, (65) : 5-16, [2] + 4 figs

Gonçalves, J. - 1957 - A pesca em Pernambuco. In Problemas da Pesca no Nordeste e em Pernámbuco, Série Política Econômica VI, Comissão do Desenvolvimento Econômico de Pernambuco, pp. 120-141, Recife

Graham, 'H.'W. \& Edwards, R. L. $-1970-$ The world biomass of marine fishes. In Fish in Nutrition, Fishing New (Books) Ltd., pp. 3-8, 2 figs., London.

Grangeiro, B. F. - $1961-$ Produtividade das pescarias de voador no Rio.Grande do Norte. Bol. Est. Pesca, Recife, 1 (3) : 15-23.

Grangeiro, B. F . - 1962 - Notas sôbre uma pescaria de linha ao largo do Rio Grande do Norte. Bol. Est. Pesca, Recife, 2 (3) : 3-9, 2 figs

Grangeiro, B. F. - 1962 - Alguns dados sôbre a biologia de voadores a produtividade das pescarias de Caiçaras (Rn) . Bol. Est. Pesca, Recife, 2 (6) : 3-8, 2 figs

Grangeiro, B. F. - 1962 - Caca de baleias ao lârgo do litoral paraibano. Bol. Est. Pesca, Recife, $2(12): 3-9$.

Grangeiro, B. F. - 1963 - Experiência com rêde de emalhar em pescarias de peixes voadores. Bol. Est. Pesca, Recife, 3 (8): 8-9.
Grangeiro, B. F. - 1963 - Observações colhidas em núcleos pesqueiros de Alagoas, Sergipe e Bahia. Bol. Est. Pesca, Recife, $3(11 / 12): 3-12$.

Gulland, J. A. - 1970 - The fish resources of the ocean. FAO Fish. Tech. Paper, Roma, (97) : $1-425,20$ figs.

Hall. D. N. F. - 1962 - Pesca de voador na Ilha de Barbados (Tradução). Bol. Est. Pesca, Recife, 2 (6) : $9-13$

Hayasi, S. et al. - 1970 - Status of the tuna fisheries in the Atlantic Ocean, 1956-67. Bul. Far Seas Fish. Res. Lab., Shimizu, (3): 1-72, 50 figs.

Hayasi, S. \& Kikawa, S. - 1970 - Comments to racional utilization of the yellowfin tuna in the Atlantic. Bul. Far Seas Fish. Res. Lab., Shimizu, (3) : 73-96, 8 figs

Hayasi, S. \& Kikawa, S. - 1970 - A comparative study on efficiency of the surface and longline fisheries for exploitation of tuna and related species. Bul. Far Seas Fish. Res. Lab., Shimizu, (3) : 97-114, 10 figs.

Hela, I. \& Laevastu, T. - 1961 - Fisheries Hidrography. Fishing News (Books) Ltd., 137 pp., 67 figs., London.

Hereda, M. G. C. - 1962 - Industria extrativa animal: pesca. In Geografia do Brasil. Grandes Regiöes - Meio-Norte $e$ Nordeste, Instituto Brasileiro de Geografia e Estatística/Conselho Nacional de Geografia, Biblioteca Geográfica Brasileira, volume III, publicação n.o $17, \mathrm{pp}$. 355-364, figs. 152-158, Rio de Janeiro.

Hughes, W. D. - 1971 - Australian shark fishery: methods and gear. Austr. Fish., Canberra, $30(3): 2-11,[16$ ests. ].

Idyll, C. P. - 1966 - Fishery Resources of the Western South Atlantic and the Caribbean Sea. Proceedings of the International Congress of $\mathrm{Nu}$ trition, reprint from volume $4,12 \mathrm{pp}$., Hamburg.

Idyll, C. P. \& De Sylva, D. - 1963 - Synopsis of biological data on albacore Thunnus alalunga (Gmelin) 1788 (Western Atlantic). FAO Fish. Rep., Roma, 2 (6) : 749-754

Idyll, C. P. \& De Sylva, D. - 1963 - Synopsis of biological data on the blackfin tuna Thunnus atlanticus (Lesson) 1830 (Western Atlantic). FAO Fish. Rep., Roma, 2 (6) : 761-770

Idyll, C. P. \& De Sylva, D. - 1963 - Synopsis of biological data on yellowfin tuna Thunnus albacares (Bonnaterre) 1788 (Western Atlantic). FAO Fish. Rep., Roma, 2 (6) : 771-777

Ihering, R. v. - $1928-$ As tainhas. Voz do Mar, Rio de Janeiro. (75) : 3-6

Ihering, R. v. - 1932 - Criando Peixes, aos Cardumes! - IV - Os primeiros passos na piscicultura brasileira - a "trahyra" e o "lambary". Chácaras e Quint., São Paulo, 45 (4) : 459-463, [5 fig..]; 45 (5) : 571-574, 4 figs.

Ihering, R. v. - 1932 - O valor do peixe nos acudes. Paraíba Agrícola, João Pessoa, (8/9) : 169-171, 2 figs.

Ihering, R. v. - 1933 - A lagosta. Bol. Secr. Agric. Ind. Viac., Recife, 2 (1/2) : 125-136.

Ihering, R. v. - 1933 - A pesca no nordeste brasileiro. Bol. Biológico, n. s., São Paulo, 2 (2) : 65-72, 2 figs.

Ihering, R. v. - 1934 - Aspectos biológicos do sertāo. Diário da Manhã , Recife, edição de janeiro de 1934

Ihering, R. v. - 1934 - Piscicultura e as Investigações Scientificas. Bol. Insp. Fed. Obr. Contr. Sêc., Fortaleza, 2 (5) : 226-231

Ihering, R. v. - 1935 - Piscicultura no Nordeste. Campo, Rio de Janeiro, 6 (10): 17-21, [8 figs.].

Ihering, R. v. - 1938 - Em prol da catalogação da tauna do Brasil. In Livro Jubilar do Professor Lauro Travassos, pp. 221-229, Rio de Janeiro. 
Ihering, R. v. - 1957 - Criação de Peixes em Viveiros do Recife. In Problemas da Pesca no Nordeste e em Pernambuco. Série Política Econômica VI, Comissão do Desenvolvimento Económico do Pernambuco, pp. 72-77, Recife.

Ihering, R. v. \& Azevedo, P. - 1934 - A curimatã dos açudes nordestinos (Prochilodus argen. teus). Arq. Inst. Biol., São Paulo, 5: 143-184, 6 figs., 4-9 ests

Ihering, R. v. \& Azevedo, P. $\rightarrow 1936-$ As piàbas dos açudes nordestinos (Characidae, Tetragonopterinae). Arq. Inst. Biol., São Paulo, 7 (8): 75-106, 2 figs., 9-12 ests.

Kempf, M. - 1970 - A plataforma continental de Pernambuco (Brasil). Nota preliminar sôbre a natureza do fundo. Trab-s. Oceanogr-s. Univ. Fed. $P e$. Recife, $9 / 11$ : $111-123,3$ figs.

Kempf, M.; Coutinho, P. N. \& Morais, J. O. - 1970 - Plataforma continental do norte e nordeste do Brasil: Nota preliminar sôbre a naturez. do fundo. Trab-s. Oceanogr-s. Univ. Fed. Pe., Recife, 9/11: 9-26, 4 figs.

Kempf, M. \& iMatthews, H. R. $-1968-$ Marine mollusks from north and northeast Brazil. I - Preliminary list. Arq. Est. Biol. Mar. Univ. Fed. Ceará, Fortaleza, 8 (1): 87-94, 1 fig.

Kristjonsson, H. - 1968 - Técnicas para localizar y capturar camarones en la pesca comercial. CARPAS/Doc. Inf., Rio de Janeiro, 4 (2): 1-69, 57 figs.

* Laevastu, T. - 1961 - Natural bases of fisheries in the Atlantic Ocean: their past and present characteristics and possibilities for future expansion. In Atlantic Ocean Fisheries, Fishing News (Books) Ltd., pp. 18-39, 8 figs., London.

Le Cren, E. D. - 1958 - Aplicación de la ciencia a la pesca continental. FAO Est. Pesca, Roma, (8) : 1-53

Lee, R. E. K. D. - 1957 - Report to the Government of Brazil on tuna fisheries development (Northeastern Coast of Brazil). FAO Report, Roma, (739) : I-II + 1-29, 24 figs., [6 pls.]

Lee, R. E. K. D. - 1963 - Pescarias de côrso múltiplo com pequenas embarcaçóes. Bol. Est. Pesca, Recife, 3 (2) : 3-5, 1 fig.

Lemos, J. - 1956 - Introdução ao estudo das pescas no Brasil. volume I. Relatório da Missão Portuguesa de Pesca no Brasil, 326 pp., $[4+1+8]$ mapas, Lisboa.

Lima, F. R. - 1962 - Considerações preliminares sóbre a pesca do pargo. Bol. Est. Pesca, Recife, 2 (12) : 14-15

Lima, F. R. - 1963 - Levantamento preliminar sôbre a pesca e biologia pesqueira do pargo. Atas IV Reun. Nac. Téc. Pesq. Pesca Mar., Recife, Anexo $I: 9$

Lima, F. R. \& Wise, J. P. - 1962 - Primeiro estudo da abundância e distribuição da albacora de laje e da albacora branca na região ocidental do Oceano Atlântico Tropical (1957-1961). Bol. Est. Pesca, Recife, 2 (10) : 12-17, 2 figs.

Lima, H. H. \& Paiva, M. P. - 1966 - Alguns dados ecológicos sôbre os peixes marinhos de Aracati. Bol. Est. Biol. Mar. Univ. Fed. Ceará, Fortaleza, (11) : 1-10

Lira, O. - 1964 - A pesca em Pernambuco (Parte I) . Bol. Est. Pesca, Recife, 4 (2): 9-14

Lira, O. - 1964 - A pesca em Pernambuco (Parte II) . Bol. Est. Pesca, Recife, 4 (3): 10-24, [3 figs.].

Luna M., J. - $1966-$ Programación del Desarrollo Pesquero. CARPAS/Doc. Téc., Rio de Janeiro, (7) : 1-56, 2 figs.

Luna M., J. - 1967 - Informe al Gobierno del Brasil sobre Desarrollo Pesquero del Brasil. Organización de las Naciones Unidas para la Agricul- tura y la Alimentación, n. ${ }^{\circ}$ AT2433: I-IV + 1-89, Roma.

Luna M., J. - 1969 - Desarrollo Pesquero de America Latina. Banco Interamericano de Desarrollo, Washington.

Mabesoone, J. M. - 1971 - Calcários Recentes do Litoral Nordestino. Est. Sedimentol., Natal, 1 (1) : 45-54, 4 figs.

Mabesoone, J. M. - 1971 - Fácies Scdimentares da Plataforma Continental Brasileira. Est. Sedimentol., Natal, 1 (1) : 55-71, [6 figs.].

Mabesoone, J. M. \& Tinoco, I. M. - $1967-$ Shelf off Alagoas and Sergipe (Northeastern Brazil). Trab-s. Inst. Oceanogr. Univ. Fed. Pe. Recife, $7 / 8: 151-185,10$ figs

Magalhães, E. - 1936 - A albacóra $e$ as possibilidades do seu aproveitamento em conserva. Serviço de Caça e Pesca, 6 pp., 3 figs., Rio de Janeiro. Magalhães, E. - 1939 - Os "atuns brasileiros": albacora, sororoca e bonito. Chácaras e Quint., São Paulo, 60 (3) : 347-349, [5 figs.].

Magalhães, E. - 1939 - Estudos relativos à pesca da albacora e às possibilidades da industrialização dêsse peixe no Estado da Paraíba. Voz do Mar, Rio de Janeiro, 18 (160) : 35-44, [13 figs.]

Maio, C. R. - 1962 - Litoral. In Geografia do Brasil. Grandes Regióes - Meio-Norte e Nordeste, Instituto Brasileiro de Geografia e Estatistica/Conselho Nacional de Geografia, Biblioteca Geográfica Brasileira, volume III, publicação n. $.^{0} 17, \mathrm{pp}$. 9-73, figs. 1-32, Rio de Janeiro.

Menezes, M. F. $\rightarrow 1968 \rightarrow$ Sôbre a alimentação do camurupim, Tarpon atlanticus (Valenciennes). no Estado do Ceará. Arq. Est. Biol. Mar. Univ.

Fed. Ceará, Fortaleza, 8 (2) : 145-149, 1 fig.

Menezes, M. F. - 1968 - Aspectos da pesca artesanal de algumas espécies marinhas no Estado do Ceará. Bol. Est. Biol. Mar. Univ. Fed. Ceará, Fortaleza, (17) : 1-11

Menezes, M. F. - 1969 - Alimentaç̃o da cavala, Scomberomorus cavalla (Cuvier), em águas costeiras do Estado do Ceará. Arq. Ciên. Mar, Fortaleza, 9 (1) : 15-20, 2 figs.

Menezes, M. F. \& Paiva, M. P. - 1966 - Notes on the biology of tarpon, Tarpon atlanticus (Cuvie! \& Valenciennes! from coastal waters of Ceará State, Brazil. Arq. Est. Biol. Mar. Univ. Fed. Ceará, Fortaleza, 6 (1) : 83-98, 11 figs

Menezes, R. S. - 1942 - Desenvolvimento da pesca e da piscicultura no nordeste. Bol. Insp. Fed. Obr. Contr. Sêc., Rio de Janeiro, 17 (1) : 3-7

Menezes, R. S. - 1944 - O peixe dos açindes em face das sécas. Voz do Mar, Rio de Janeiro, 24 (16) : 12 .

Menezes, R. S. - $1944 \rightarrow$ Pesca e piscicultura no Nordeste. Caça e Pesca, São Paulo, 4 (40): 15-16

Menezes, R. S. $-1945 \rightarrow$ A pesca nos açudes. Considerações gerais. Rev. Caça e Pesca do Brasil, Rio de Janeiro, 2 (12/14) : 25-26

Menezes, R. S. - 1945 - O peixe dos açudes como fator bio-económico. Campo, Rio de Janeiro. $16(184): 33-38 ; 16$ (185) : 61-64

Menezes, R. S. - 1948 - Importância da piscicultura na economia do Nordeste. Publ. Serv. Piscicultura, Fortaleza, (115) : 1-11.

Menezes, R. S. - 1951 - Obstáculos à Pesca Nos Açudes Do Nordeste. Bol. Secret. Agric. Ind. Viaç., Recife, $18(1 / 2): 7-10$

Menezes, R. S. - 1951 - Contribuição ao Estudo da Piscicultura e Pesca Interior no Estado de Alagoas. Ministério da Agricultura, Divisão de Fomento da Produção Vegetal, 49 pp., 6 figs., Maceió .

Menezes, R. S. - 1952 - Aclimação de Peixes Nos Açudes Do Nordeste. Bol. Secret. Agric. Ind. Viaç., Recife, 19 (1/2) : 119-122. 
Menezes, R. S. - 1952 - O Pirarucu Nos Açudes Do Nordeste. Bol. Secret. Agric. Ind. Viac., Recife, $19(1 / 2): 151-153$

Menezes, R. S. - 1953 - Pesca Maritima e Pesca D'Água Doce. Piscicultura Em Águas Doces e Salôbras. Bol. Secret. Agric. Ind. Com., Recife, $20(3 / 4): 71-102,1$ est.

Menezes, R. S. - 1955 - Pesca e Piscicultura no Vale do São Francisco. Bol. Secret. Agric. Ind. Com., Recife, 23 (3/4) : 43-105

Menezes, R. S. - 1956 - O Surubim do Rio São Francisco. Bol. Secret. Ind. Com. Bahia, Salvador, 52 (16) : 63-65

Menezes, R. S. - 1956 - Perspectivas da pesca e piscicultura na Bahia. Bol. Secret. Ind. Com. Bahia, Salvador, (17) , 1-35

Menezcs, R. S. - 1957 - o fomento di pesca e da piscicultura no vale do São Francisco. Presidência da República, Conselho Coordenzdor do Abastecimento, 9 pp., Rio de Janeiro.

Menezes, R. S. - 1957 - Possibilidades de Expansão da. Pesca Marítima no Nordeste e Leste Setentrional do Brasil. In Problemas da Pesca no Nordeste e em Pernambuco, Série Política Econômica VI, Comissāo de Desenvolvimento Eçnômico de Pernambuco, pp. 11-71, [2 figs.], Recife.

Menezes, R. S. - 1957 - Produção de pescado no Vale do Sāo Francisco. Correio da Manhã, Rio de Janeiro, ed. 1/12/57: 11

Menezes, R. S. - 1959 - O dourado do Rio São Francisco. Caça e Pesca, São Paulo, 18 (212) : 17

Menezes, R. S. - 1959 - Pescado no Médio São Francisco. Caça e Pesca, São Paulo, 18 (215) : 12 .

* Menezes, R. S. - 1964 - Pesca no Nordeste.

In Recursos e Necessidades do Nordeste, Banco do Nordeste do Brasil S. A., Departamento de Estudos Económicos do Nordeste (ETENE), pp. 369-388, Recife.

Menezcs, R. S. - 1969 - Pesca Continental e Piscicultura no Nordeste. Bol: DNOCS, Sér. Fom. Prod., Fortaleza, $27(2 / 4): 65-72$

Menezes, R. S. \& Menezes, M. F. - 1968 Estudo preliminar sốbre a flora $\mathrm{e}$ fauna de águas estuarinas no Estado do Ceará. Arq. Est. Biol. Mar. Univ. Fed. Ceará, Fortaleza, 8 (1) : 101-106

Menezcs, R. S. \& Paiva, M. P. - $1965-$ Dados sóbre a pesca artesanal no Ceará em 1964. Col. Est. Pesca, Fortaleza, $1: 1-12$.

Mihara, T. \& Leon, A. B. - 1970 -- Observaciones sobre la pesca del tiburón con palangre de fondo en el Oriente de Venezuela. Proyecto de Investigación y Desarrollo Pcsquero, Inf. Téc., Caracas, (4) : 5-9, 2 figs

Moal, R. A. - 1960 - Problemes poses par lorganisation et le developpement des pêches maritimes dans le Nord-Est du Brésil. Societé Centralle pour l'Equipement du Territoire - Cooperation, 154 pp.. Paris

Monte, S. - 1964 - Observações sōbre a estrutura histológica das gônadas da albacora, Thunnus atlanticus (Lesson), no nordeste do Brasil. Bol. Inst. Biol. Mar. Univ. R. G. Norte, Natal, 1 : 17-31 10 figs.

Moraes, M. N. - 1962 - Development of the tuna fishery of Brazil and preliminary analysis of the first three year's data. Arq. Est. Biol. Mar.

Univ. Ceará, Fortaleza, 2 (2) : 35-57, 3 figs.

Morais, J. O. - 1969 - Aspectos correlativos de geologia litoral e submarina no nordeste do Brasil. Arq. Ciên. Mar, Fortaleza, 9 (1) : 127-131, 5 figs.

Morais, J. O. - 1970 - Con tribuição ao estudo dos "beach-rocks" do nordeste do Brasil. Trab-s. Oceanogr-s. Univ. Fed. Pe., Recife, 9/11: 79-94, 2 figs.

Morais, J. O. \& Souza, J. V. - 1971 - Transporte e Sedimentaçāo de Dunas no Municipio de
Fortaleza (Ceará - Brasil) . Est. Sedimentol., Natal, 1 (1) : 73-81, 7 figs.

Morais, S. B. - 1963 - Uma pescaria do atuneiro "Kaiko Maru 12". Bol. Est. Pesca, Recife, 3 (5) : 15-18

Morais, S. B - 1964 - A pesca em Salvador e no litoral sul do Estado da Bahia. Bol. Est. Pesca, Recife, 4 (3) : 5-9

Mota-Alves, M. I. - 1969 - Produção pesqueira de botes motorizados no litoral sul de Pernambuco. Equipesca Jornal, Campinas, (30) : 11

Moura, S. J. C. - 1962 - Pesca de lagosta na costa nordestina. II - Tipos de covos. Bol. Est. Pesca, Recife, 2 (4) : 10-11, 3 figs.

Moura, S. J . C . - 1962 - Análise das variaçỏes estacionais da produção de lagosta na Paraíba. Bol. Est. Pesca, R乞cife, 2 (8) : 3-6, [2 figs.]

Moura, S. J. C. - 1963 - Experiências com rêdes de espera em pescarias de lagosta. Bol. Est. Pesca, Recife, 3 (3): 3-9, [1 fig.].

Moura, S. J. C. - 1963 - Contribuição ao estudo sôbre as variações de produtividade das pescarias de lagostas na costa oriental do nordeste brasileiro e flutuações na composição dos desembarques na praia do Pina (Pe). Bol. Est. Pesca, Recife, $3(9 / 10), 7-19,[3]+4$ figs

Moura, S. J. C. \& Paiva, M. P. - 1965 - Considerações sôbre a produção de pescado do Território de Fernando de Noronha. Bol. Est. Biol. Mar. Univ. Ceará, Fortaleza, (10): 1-11, 2 figs.

Nagai, M. - 1957 - Tuna long-line fishing gear and methods. Comm. Fish. Rev., Washington, 19 (12) : 64-67

Nakamura, H. et al. - 1958' - Tôkô Maru in yoru tchunambei guioba tchôsa hokokusho 1956 nen 10 gatsu - 1957 nen 7 gatsu). Suisan-tchô, 6 +279 pp., 176 figs., $2+228$ pp., $104+16$ figs., Tokyo

Nascimento, I. V. - 1968 - Estudos preliminares sôbre a primeira maturação sexual e "sex-ratio" do sururu (Mytella falcata, Orbigny 1846) . Bol. Est. Pesca, Recife, 8 (2): 41-50, 5 figs.

Nascimento, I. V. - 1968 - Estudo preliminar da maturidade do Sururu (Mytella falcata, Orbigny 1846) . Bol. Est. Pesca, Recife, 8 (3) : 19-33, 12 figs. Nascimento, I. V. - 1969 - Sôbre a reprodução do sururu, Mytella falcata (Orbigny 1846) . Bol. Est. Pesca, Recife, 9 (1) : 51-64, 7 figs.

Neumann, G. - 1965 - Oceanography of the Tropical Atlantic. Anais Acad. Bras. Ciênc., Rio de Janeiro, 37 (suplemento): 63-82, 12 figs.

Nomura, H. - 1964 - Pescarias de jangadas no litoral sul de Pernambuco. Bol. Soc. Cear. Agron., Fortaleza, 5 : $67-76$

Nomura, H. - 1967 - Dados biológicos sôbre a serra, Scomberomorus maculatus (Mitchill), das águas cearenses. Arq. Est. Biol. Mar. Univ. Fed. Ceará, Fortaleza, 7 (1) : 29-39, 4 figs.

Nomura, H. \& Fausto Filho, J. - $1966-$ Shrimp survey in coastal and offshore waters of northeastern and northern Brazil. Arq. Est. Biol. Mar. Univ. Fed. Ceará, Fortaleza, 6 (1) : 15-29, 6 figs.

Nomura, H. \& Fausto Filho, J . $-1968-\Lambda$ shrimp exploratory survey in northern and northeastern Brazil, with some biological observations on Penaeus astecus. FAO Fish. Rep., Roma, 2 (57): $219-231,1$ fig.

Nomura, H.; Paiva, M. P. \& Buesa Más, R. J - 1965 - Pescarias cubanas de atuns e afins em 1963. Arq. Est. Biol. Mar. Univ. Ceará, Fortaleza, 5 (2) : 119-126

Nomura, H. \& Rodrigues, M. S. S. $-1967-$ Biological notes on king mackerel, Scomberomorus cavalla (Cuvier), from northeastern Brazil. Arq. Est. Biol. Mar. Univ. Fed. Ceará, Fortaleza, 7 (1) : 79-85, 4 figs. 
Okuda, T. - 1960 - Chemical oceanography in the South Atlantic Ocean, adjacent to northeastern Brazil. Trabs. IBMO-UR, Recife, 2 (1): 155-174, 18 figs.

Okuda, T. \& Cavalcanti, L. B. -- 1963 - Algumas condiçōes oceanográficas na área nordeste de Natal (Setembro 1960। . Trabs. I. O.-U.R., Recife, 3 (1) : $3-25,19$ figs

Okuda, T. et al. - 1963 - Nota sỏbre as condições hidrográficas no Açude Acari - R. G. do Norte - Brasil. Trabs. I.O.-U.R., Recife, 3 (1): 33-38, 2 figs.

Osorio-Tafall, B. F. - 1951 - Better utilization of fisheries in Latin America. FAO Fish. Bull:, Roma, 4 (3) : 2-25, 1 fig

Ottmann, F. et al. - 1967 - Estudo da Barra das Jangadas - Parte V - Efeitos da poluição sóbre a ecologia do estuário. Trab-s. Inst. Oceanogr. Univ. Fed. Pe., Recife, 7/8: 7-16

Paiva, M. P. - 1958 - On the spiny lobster fishing in Ceará. Bol. Antropologia, Fortaleza, 2 (1) : 63-70, 2 figs

Paiva, M. P - 1959 - Exploração da lagosta no Ceará. Mundo Agrário, Rio de Janeiro, 7 (97) : 17

Paiva, M. P. - 1959 - Notas biológicas sôbre os atuns. Mundo Agrário, Rio de Janeiro, 7 (99) : 37 .

Paiva, M. P. - 1959 - Perspectivas da cxploração lagosteira no Rio Grande do Norte. Munlo Agrário, Rio de Janeiro, 8 (101) : 20,1 fig

Paiva, M. P. - 1960 - Sôbre as iscas nas pescarias de jangada ao largo de Fortaleza ICeará Brasil) . Rev. Nac. Pesca, São Paulo, 1 (4) : 15-16.

Paiva, M. P. - 1960 - Introdução ao conhecimento da pesca marítima no nordeste brasileiro. Rev. Nac. Pesca, São Paulo, 1 (5) : 18-20

Paiva, M. P - 1960 - Sinopse sôbre a pesca interior no Brasil. Rev. Nac. Pesca, São Paulo, 1 (6) : 41-42

Paiva, M. P. - 1961 - Consideraçòes söbre a pesca em Macau - Rio Grande do Norte. Rev. Nac. Pesca, São Paulo, 2 (10) : 31-33, [3 figs. 1

Paiva, M. P. - 1961 - Acão da pesca sôbre as espécies de lagostas no Ceará. Bol. Est. Biol. Mar. Univ. Ceará, Fortaleza. (1) : 1-5

Paiva, M. P. - 1961 - Recursos básicos da pesca maritima no nordeste brasileiro. Bol. Est. Biol. Mar. Univ. Ceará, Fortaleza, (3) : 1-10

Paiva, M. P. - 1961 - Sôbre a pesca de atuns e afins nas áreas em exploração no Atlântico Tropical. Arq. Est. Biol. Mar. Univ. Ceará, Fortaleza, 1 (1): 1-20, 8 figs

Paiva, M. P. - 1961 - Cartas de pesca para os atuns $\mathrm{e}$ afins no Atlântico Tropical. Arq. Est. Biol. Mar. Univ. Ceará, Fortaleza, 1 (2) : 1-110. 96 figs.

Paiva, M. P. - 1961 - Sóbre a Biologia e a Pesca das Lagostas em Pernambuco (BRASIL). Bol. Pesca, Lisboa, (73) : 11-21, 7 figs

Paiva, M. P. - $1962 \rightarrow$ Uma experiéncia de pesca comercial com caíques, ao longo da costa setentrional do nordeste brasileiro. Rev. Nac. Pesca, São Paulo, 3 (12) : 36

Paiva, M. P. - 1962 - As pescas maritimas e o abastecimento no Ceará. Rev. Nac. Pesca, São Paulo, 3 (13) : 30-31

Paiva, M. P. - 1962 -Actual status of the knowledge on the biology of tunas in offshore waters of the brazilian coast. Bol. Est. Biol. Mar. Univ. Ceará, Fortaleza, (5) : 1-10

Paiva, M. P. - 1962 - Notas sôbre os atuns do Brasil. Arq. Mus. Nac., Rio de Janciro, 52: 145-150, 4 figs.

Paiva, M. P. - 1963 - Informes sôbre a biologia e a pesca de camarões marinhos. Rev. Nac. Pesca, São Paulo, 4 (24) : 19 .
Paiva, M. P. - $1963-$ Sinopse sôbre as aguas interiores do nordeste brasileiro. Bol. Soc. Cear Agron., Fortaleza, 4: 1-15

Paiva, M. P. - 1965 - Sóbre o melhoramento das embarcações de pesca artesanal do nordeste brasileiro. Rev. Nac. Pesca, São Paulo, 5\% 139!: 17-18

Paiva, M. P. - 1965 - Dados sôbre a densidade relativa de lagostas na costa cearense em 1964 Arq. Est. Biol. Mar. Univ. Ceará, Fortaleza, 5 (1) : 1-9, 3 figs

Paiva, M. P. - 1965 - Dinâmica da pesca de lagostas no Ceará. Arq. Est. Biol Mar. Univ. Ceará, Fortaleza, 5 (2) : 151-174, 5 figs.

Paiva, M. P. - 1966 - Esiudo sôbre a pesca de lagostas no Ceará, durante o ano de 1965 . Arq. Est. Biol. Mar. Univ. Fed. Ceará, Fortaleza.6 (2): 147-165, 9 figs.

* Paiva, M. P. - 1966 - Dados sổbre a pesca artesanal no Ceará em 1965 . Bol. Est'. Biól. 'Mar'. Univ. Fed. Ceará, Fortaleza, (12): 1-46, 2 figs.

Paiva, M. P. - 1967 - Algunos problemas de la industria langostera en el Brasil. Arq. Est. Biol. Mar. Univ. Fed. Ceará, Fortaleza, 7 (2) : 105-112

Paiva, M. P. - 1967 - Estudo sôbre a pesca de lagostas no Ceará, durante o ano de 1966 . Arq. Est. Biol. Mar. Univ. Fed. Ceará, Fortaleza, 7 12): $123-142 ; 9$ figs.

Paiva, M. P. - 1967 - On the tuna conservation in the Atlantic. Arq. Est. Biol. Mar. Univ. Fed. Ceará, Fortaleza, 7 (2) : 192-193

Paiva, M. P. - 1967 - Considerações sôbre os recursos pesqueiros marinhos do Estado do Maranhão. Equipesca Jornal, Campinas, 4 (15): [6-71, [2 figs.].

Paiva, M. P. - 1968 - Estudo sóbre a pesca de lagostas no Ceará, durante o ano de 1967 . Arq. Est. Biol. Mar. Univ, Fed. Ceari, Fortaleza, 8 (1): $47-64,5$ figs.

Paiva, M. P. - 1968 - Sôbre os recursos pesqueiros do Estado do Ceará. CARPAS/Doc. Téc., Rio de Janeiro, 4 (27) : 1-3

Paiva, M. P. - 1968 - Informe soobre as migracões tróficas e genéticas de espécies de importância comercial para a pesca brasileira. Bol. Soć. Cear. Agron., Fortaleza, 9: 29-36.

Paiva, M. P. - 1969 - Estudo sóbre a pesca de lagostas no Ceará, durante o ano de 1968 . Arq. Cièn. Mar, Fortaleza, 9. (1) : 41-55, 5 figs.

Paiva, M. P. - 1969 - Situação atual e principais problemas das investigaçós sobre lagostas no Estado do Ceará. Pesca Pesquis ., Rio de Janeiro, $2(3 / 4): 105-113$

Paiva, M. P. - 1970 - Sumário de informaçōes sobre os crustáceos de valor comercial no norte $c$ nordeste do Brasil. Anuário da Pesca, São Paulo, 1970: 97-104

Paiva, M. P. - 1970 - Estudo sòbre a pesca de lagostas no Ceará, durante o ano de $1969 ; A r q$. Ciên. Mar, Fortaleza, 10 (1): 91-103, 5 figs.

Paiva, M. P. \& Bezerra, R. C. F. $-1969-$ Algumas tendèncias recentes da pesca de lagostas no Estado do Ceará. Bol. Cear. Agron., Fortaleza, 10 : $11-15,1 \mathrm{fig}$.

Paiva, M. P. \& Braga, I. B. - $1968-$ Dados sôbre a pesca artesanal no litoral do Ceará no ano de 1966. Superintendência do Desenvovimento Econômico e Cultural (SUDEC) - Setor de Biblioteconomia e Documentação, 84 pp., 12 figs., Fortaleza.

Paiva, M. P. \& Braga, I. B. - 1968 - Estatísticas das pescas marítimas do Estado do Ceará no ano de 1967 . Bol. Est. Pesca, Recife, 8 (1) : 7-37, 16 tabelas em páginas não numeradas.

Paiva, M. P. \& Cervigón, F. - 1969 LoS recursos pesqueros del nordeste de sudamerica. Mem. Soc. Cienc. Nat. La Salle, Caracas, 29 (82) : 60-71. 
Paiva. M. P. \& Costa, R. S. - 1963 - Estudos de biologia da pesca de lagostas no Ceará - Dados de 1962, Arq. Est. Biol. Mar. Univ. Ceará, Fortaleza, 3 (1) : 27-52, 7 figs

Paiva, M. P. \& Costa, R. S. - 1963 - Informações sỏbre as pescas maritimas no Estado do Rio Grande do Norte. Bol. Soc. Cear. Agron., Fortaleza, $4: 25-37$

Paiva. M. P. \& Costa, R. S. - 1964 - Estudos de biologia da pesca de lagostas no Ceará -- Dados de 1963. Arq. Est. Biol. Mar. Univ. Ceará, Fortaleza, 4 (2) : 45-70, 7 figs

Paiva, M. P. \& Costa, R. S. - 1965 - Estudos de biologia da pesca de lagostas no Ceará - Dados de 1964 . Arq. Est. Biol. Mar. Univ. Ceara, Fortaleza, 5 (2): 127-150.9 figs.

Paiva, M. P. \& Costa, R. S. - 1966 - Estudos de biologia da pesca de lagostas no Ceará - Dados de 1965. Arq. Est. Biol. Mar. Univ. Fed. Ceará, Fortaleza, 6 (2) : $167-193,9$ figs

Paiva, M. P. \& Costa, R. S. - 1967 - Estudos de biologia da pesca de lagostas no Ceará - Dados de 1966. Arq. Est. Biol. Mar. Univ. Fed. Ceará, Fortaleza, 7 (2): 147-171, 9 figs.

Paiva, M. P. \& Costa, R. S. - 1968 - Comportamento biológico da lagosta Panulirus laevicauda (Latreille) . Arq. Est. Biol. Mar. Univ. Fed. Ceará, Fortaleza, 811$): 1-6,5$ figs

Paiva, M. P. \& Costa, R. S. - 1968 - Estudos de biologia da pesca de lagostas no Ceará - Dados de 1967. Arq. Est. Biol. Mar. Univ. Fed. Ceará, Fortaleza, 8 (2) : 187-210, 9 fig.

Paiva, M. P. \& Costa, R. S. - 1969 - Estudos de biologia da pesca de lagostas no Ceará - Dados de 1968. Arq. Ciên. Mar, Fortaleza, 9 (2): 133-146, 5 figs.

Paiva. M. P. \& Costa, R. S. - $1970-$ Estudos de biologia da pesca de lagostas no Ceará - Dados de 1969. Arq. Ciên. Mar, Fortaleza, 10 (2): 131142.5 figs.

Paiva, M. P. \& Fonteles Filho, A. A. - 1968 Sôbre as migrações e índices de exploração da lagosta Panulirus argus (Latreille), ao longo da costa do Estado do Ceará. Arq. Est. Biol. Mar. Univ. Fed. Ceará, Fortaleza, 8 (1) : 15-23, 6 figs

Paiva, M. P. \& Fonteles Filho. A. A. - 1968 - Sôbre a produção pesqueira de alguns currais-de- pesca do Ceará - Dados de 1965 a 1967 . Bol. Est. Biol. Mar. Univ. Fed. Ceará, Fortaleza, (16): $1-8$

Paiva, M. P. \& Grangeiro, B. F. - $1965-$ Biological investigations on the whaling seasons 1960-1963, off northeastern coast of Brasil. Arq. Fist. Biol Mar. Univ. Ceará. Fortaleza. 5 (1): 29-64, 44 figs.

Paiva, M. P. \& Grangeiro, B. F. $-1970 \ldots$ Investigations on the whaling seasons $1964-1967$, off northeastern coast of Brazil. Arq. Ciên. Mar, Fortaleza, 10 (2) : 111-126

Paiva, M. P. \& Menezes, R. S. - 1967 - Pescarias costeiras de botes motorizados no litoral sul de Pernambuco. Equipesca Jornal, Campinas, 4 (14) : [7-8]

Paiva, M. P. \& Mota, M. I. - 1961 - Atividades do "Albacora" em 1960 . Bol. Est. Biol. Mar Univ. Ceurá, Fortaleza, (4): 1-18, 11 figs

Paiva, M. P. \& Moura, J. V. - 1960 - Sôbre as "safras" nas pescarias de jangada ao largo de Fortaleza (Ceará, Brasil). Bol. Soc. Cear. Agron. Fortaleza, 1: 73-76

Paiva, M. P. \& Moura, S. J. C. - 1965 - Consideraçōes sôbre a exportação nacional de caudas congeladas de lagostas. Bol. Est. Biol. Mar. Univ. Ceará, Fortaleza, (8) : 1-17, 5 figs.

Paiva, M. P. \& Moura, S. J. C. - 1965 - Sôbre a classificação da exportação nacional de caudas de lagostas. Bol. Est. Biol. Mar. Univ. Ceará, Fortaleza, (9) : 1-8, $1 \mathrm{fig}$

Paiva, M. P. \& Muniz, E. J. - 1964 - Pescarias de pequeno atuneiro, ao largo do nordeste brasileiro. Bol. Est. Biol. Mar. Univ. Ceará, Fortaleza. (6) : 1-11, 1 fig

Paiva, M. P. \& Nomura. H. - 1965 - Sôbre a produção pesqueira de alguns currais-de-pesca do Ceará - Dados de 1962 a 1964. Arq. Est. Biol. Mar. Univ. Ceará, Fortaleza, 5 (2): 175-214, 42 figs.

Paiva, M. P. \& Pitombeira, M. H. - $1962-$ Ação da pesca sôbre os sexos e tamanhos da lagosta Panuirus argus (Latr.) da costa do Ceará. Arq. Mus. Nac., Rio de Janeiro, 52: 169-177, 3 figs

Paiva, M. P. \& Silva, A. B. - 1962 - Estudos de biologia da pesca de lagostas no Ceará - Dados de 1961 . Arq. Est. Biol. Mar. Univ. Ceará, Fortaleza, 2 (2) : 21-34, 7 figs

Pereira-Barros, J. B. - 1966 - Consideraçōes sôbre a pesca e bioecologia do sururu Mytella falcata (Orbigny, 1846) . VII Reun. Nac. Téc. Pesq. Pesca Mar., Santos, (53-54) : 1

Pereira-Barros, J B - 1967 - Pesca e produtividade do sururu. Bol. Est. Pesca, Recife, 7 (1) : 41-58, 5 figs

* Pereira-Barros, J. B. - 1969 - Estudos bioecológicos da Lagoa Mundaú - Maceió, Alagoas. Documento de Pesca, Recife, (20): [7] + 29 pp.

Pereira-Barros, J. B. - 1971 - Informes sôbre a pesca na Lagoa Mundaú (Alagoas) (Peixes, camarões, siris). CARPAS/Doc. Téc., Rio de Janeiro, 5 (27) : 1-14

Pereira-Barros, J. B. \& Macêdo, S. J. - 1967 - Criação do sururu Mytella falcata (Orbigny, 1846) em laboratório. Bol. Est. Pesca, Recife, 7 (2) : 31-42, 2 figs.

Pereira-Barros, J. B. \& Santos, E. P. - 1969 - Sôbre a estimação da taxa de mortalidade na populacão do molusco Mytella falcata (Orbigny) 1846 , da Lagoa Mundaú - Alagoas. Bol. Est. Pesca, Recife, 9 (1) : 35-50, 5 figs

Pinheiro-Vieira, F. \& Ferreira, M. M. - 1968 - Algas marinhas de interêsse industrial para 0 nordeste brasileiro. Bol. Est. Biol. Mar. Univ. Fed. Ceará, Fortaleza, (20) : 1-9

Pompeu Sobrinho, Th - 1953 - Historia do Ceará - História das Sêcas (Século $X X$ ). Instituto do Ceará, $541 \mathrm{pp}$., [24] tabelas em páginas não numeradas, Fortaleza.

Postel, E. - 1962 - L'evolution de la péche au thon. Les japonais dans l'Atlantique, La Pêche $M a-$ ritime, Paris, 41 (1013) : 579-583, 6 figs

Postel, E. - 1969 - Répartition et abondance des thons dans l'Atlantique Tropical Sym. Oceanogr. Fish. Res. Trop. Atlantic, Paris, pp. 109-138, 32 figs

Postel, E. - 1969 - Présentation des thons. $L a$ Pêche Maritime, Paris, (1095): 397-415, 11j + 25 figs

Postel, E. - 1969 - Présentation des crevettes. La Pêche Maritime, Paris, (1095) : 426-433, [1] +4 figs

Rathjen, W. F. \& Hsu, B. C. C. - 1970 - Sea bob fishery of the Guianas. Comm. Fish. Rev. Washington, $32(10): 38-44,10$ figs

Richardson, I. D. - 1964 - Estimación de los recursos marinos frente a la costa atlántica de América del Sur. Serv. Hidr. Naval, Buenos Aires, $(\mathrm{H}-1020): 5+25 \mathrm{pp}$., 4 figs.

Ripley, W. E. - 1956 - Relatório ao Govèrno do Brasil sôbre Biologia da Pesca. Relatório FAO/ ETAP, Roma, (494) : $23+15$ pp., 15 figs.

Rodrigues, M. S. S. - 1968 - Idade e crescimento da cururuca, Micropogon furnieri (Desmarest, 1822), nas águas cearenses. Arq. Est. Biol. Mar. Univ. Fed. Ceará, Fortaleza, 8 (1) : 7-14, 6 figs. 
Rosa, Jr., H. - 1957 - Synopsis of Data on Whales. Food and Agriculture Organization of the United Nations, 44 pp., 31 tables, [1] + 11 figs., Roma.

Santos, E. - $1952-$ Nossos peixes marinhos ( $v i d a$ e costumes dos peixes do Brasil). F. Briguiet \& Cia., 267 pp., 185 figs., Rio de Janeiro.

Santos, E. - 1954 - Peixes da água doce (Vida e costumes dos peixes do Brasil). F. Briguiet \& Cia., 270 pp., 126 figs., 7 ests., Rio de Janeiro.

Schubart, O. - 1935 - Viveiros do Recife. Pecus, Recife, 1 (2) : 15-19; 1 (3) : 10-14, 5 figs.

Shubart, O. - 1936 - Investigaçōes sôbre os viveiros do Recife. Bol. Serv. Agr. Pe., Recifc, 1: 153-176, 11 figs.

Schubart, O. - 1944 - A nesca nos Estados de Pernambuco e Alagoas. Ministério da Agricultura. Divisão de Caça e Pesca, 61 pp., I8 ests.], Rio de Janeiro.

Schubart, O. - 1957 - Investigacões sôbre os viveiros do Recife. In Problemas da Pesca no Nordeste e em Pernambuco. Série Politica Econômica VI, Comissão do Desenvolvimento Económico de Pernambuco, pp. 88-114, 7 figs.. Recife.

Schuster, W. H. et al. - 1954 - Fish Farming and Inland Fisheries Management in Rural Economy. FAO Fisheries Study, Roma, (3) : I-VIII † $1-64,16$ figs

Seraine, F. - 1958 - Curral-de-pesca no litoral cearense. Bol. Antropologia, Fortaleza, 2 (1) : 21-44, 12 figs.

Shelbourne, J. E. - 1968 - Report on the possibilities for marine cultivation in Brazil. The British Council, 13 pp., Rio de Janeiro.

Silva, J. E, - 1970 - Nota prévia sôbre viveiros de peixes situados em Itamaracá, Pernambuco (Brasil). Trab-s. Oceanogr-s. Univ. Fed. Pe., Recife, $9 / 11: 317-324,1$ mapa.

Silva, J. W. B. - $1969-$ Considerações Sôbre a Pesca no Acude "Pereira de Miranda" (Pen Łecoste. Ceará, Brasil). Bol. DNOCS, Sér. Fom. Prod., Fortaleza, $27(2 / 4): 45-59,5$ figs.

Silva, J. W. B. - 1970 - Ocorrência e causas de depleção de curimatã comum, Prochilodus cearensis Steindachner, no açude público "Forquilha" (Sobral, Ceará, Brasil). Bol. Téc. Dep. Nac. Obr. Cont. Sêc., Fortaleza, 28 (1) : 9-26, 3 figs.

Silva, J. W. B. - 1970 - Ocorrência e causas de deplecão de curimatã comum, "Prochilodus ceasensis" Steindachner, no açude público "General Sampaio" (General Sampaio, Ceará, Brasil). Bol. Téc. Dep. Nac. Obr. Cont. Sêc., Fortaleza. 28 (1) : $53-70,2$ figs.

Silva, P. C. M. - 1965 - Problemas de circulação oceânica nas águas brasileiras. Anais Acad. Bras. Ciênc., Rio de Janeiro, 37 (suplemento): 157-158.

Simöes, R. M. A. - 1957 - Os regimes dos rios brasileiros. Rev. Bras. Geogr., Rio de Janeiro, 2 : 225-243 [4] +7 figs

Steffan, E. R. - 1962 - Hidrografia. In Geografia do Brasil. Grandes Regióes - Meio-Norte e Nordeste, Instituto Brasileiro de Geografia e Estatistica/Conselho Nacional de Geografia, Biblioteca Geográfica Brasileira, volume III, publicação n. ${ }^{\circ}$ 17 , pp. 95-112, figs. 41-51, Rio de Janeiro.

Stephens, W. M. - 1965 - Land Crabs. Sea Frontiers, Miami, 11 (4) : 194-201, [6 figs.] .

SUDENE - 1965 - Informaçốes sôbre oportunidades industriais referentes $\dot{a}$ atividade pesqueira no nordeste brasileiro. Superintendência do Desenvolvimento do Nordeste, Grupo Coordenador do Desenvolvimento da Pesca, [34] pp., ilus., Recife.

SUDENE - 1966 - Informaçốes à indústria de pesca. Superintendência do Desenvolvimento do Nordeste, Grupo Coordenador do Desenvolvimento da Pesca, Divisão de Documentação, DOP-6, 79 pp., Recife.
SUDENE - 1969 - Projeto Akaroa. Documento de Pesca, Recife, (19): 1-48, 3 figs., 7 mapas.

SUDEPE - 1967 - Consideraçôes sóbre a atividade pesqueira na área da Delegacia Regional Nordeste Oriental. Superintendência do Desenvolvimento da Pesca, Delegacia Regional Nordeste Oriental, 58 pp., Recife.

SUDEPE - 1970 - II Plano Nacional do Desenvolvimento da Pesca. Superintendência do Desenvolvimento da Pesca, $156 \mathrm{pp}$., Rio de Janeiro.

Sverdrup, H. U. - 1952 - Some aspects of the primary production of the sea. FAO Fish. Bull., Roma, 5 (6) : 3-11

Tartari, S. C. - 1966 - Levantamento das atividades pesqueiras en Alacaju (Sergipe). A Pesca no Nordeste, Recife, $1: 36-39$

Tartari, S. C. - 1966 - Levantamento das atividades pesqueiras em Salvador (Bahia). A Pesca no Nordeste, Recife, 1 : 40-44

Teixeira, C. \& Tundisi, J. - 1967 - Primary production and phytoplankton in equatorial waters. Bull. Mar. Sci., Coral Gables, 17 (4) : 884-891, 3 figs.

Tiews, K. - 1963 - Synopsis of biological data on bluefin tuna Thunnus thynnus (Linnaeus) 1758 (Atlantic and Mediterranean). FAO Fish. Rep., Roma, 2 (6) : 422-481, 14 figs

Travassos, H. P. - $1958-$ Alguns aspectos da pesca no Vale do $S$. Francisco. Museu Nacional, 3 pp. datilografadas, Rio de Janeiro.

Vageler, P. - 1953 - Contribuição para o Problema da Sêca. Rev. Bras. Geogr., Rio de Janeiro, 15 (1) : 156-161.

Varoli, E. - 1968 - Desenvolvimento futuro da pesca brasileira (IV) . Equipesca Jornal, Campinas, (23) : 2-4

Vieira, B. B. - 1941 - Pirarucu nos Açudes do Nordeste. Observador Económico Financeiro, Rio de Janeiro, (62) : 33-35, 13 figs.]

Watase, S. - 1961 - Burajiru no kujira to hôguei (Whale fishing in Brazil). Communication n. 121 from Eujirá gueilui kenkiujô (Whales Research Institute), Tokyo, 21 pp., 7 figs. (Portuguese translation made by $\mathrm{Ko}$ Watanabe, Yoshi and $\mathrm{Hi}-$ toshi Nomura - typewritten).

Wickham, D. A. - 1971 - Harvesting coastal pelagic fishes with artificial light \& purse seine. Comm. Fish. Rev., Washington, 33 (1): 30-38, 6 figs.

* Wise, J. P. \& Le Guen, J. C. - 1969 - The Japanese Atlantic long-line fishery 1956-1963. Sym. Ocennogr. Fish. Res. Trop. Atlantic, Paris, pp $317-347,6$ figs.

Wright, S. - 1934 - Alguns dados da phisica e da chimica das águas dos Açudes Nordestinos. Bol. Insp. Fed. Obr. Contr. Sêc., Fortaleza, 1 (4): 164-169, [4 ests.].

Wright, S. - 1937 - Da Physica e da Chimica das águas do Nordeste do Brasil. III . Condiçōes Thermicas. Bol. Insp. Fed. Obr. Contr. Sêc., Rio de Janeiro, 8 (2) : 179-186, 4 ests.

Wright, S. - 1938 - Da Física e da Quimica das águas do Nordeste do Brasil. IV . Condiçóes Químicas. Bol. Insp. Fed. Obr. Contr. Sêc., Rio de Janeiro, 10 (1) : 37-54, 6 ests.

Yang, R. et al. $-1969-$ Morphometric studies on the Atlantic albacore and yellowfin tuna. Bull. Far Seas Fish. Res. Lab., Shimizu, (2) : 591-632, 9 figs.

Zembruscki, S. G. - 1968 - Geologia e magnetometria submarina na plataforma continental de Alagôas, Sergipe, Bahia e Espírito Santo. Diretoria de Hidrografia e Navegação, DG 26-XI : 531-578, 2 figs., Rio de Janeiro. 


\section{0 - GLOSSARIO DE NOMES VULGARES}

Agulha preta $=$ Hemirhamphus brasiliensis (Linnaeus); agulhas = espécies das famílias Hemirhamphidae e Belonidae; albacora azul = Thunnus thynnus (Linnaeus); albacora branca $=$ Thunnus alalunga (Gmelin); albacora laje = Thunnus albacares (Bonnaterre); albacora ôlho grande = Thunnus obesus (Lowe); albacorinha = Thunnus atlanticus (Lesson); algas = espécies de Rhodophyceae (grupo que abriga as 21 espécies de interêsse industrial para o nordeste brasileiro); atuns = espécies do gênero Thunnus South; bagres de águas doces = espécies da família Pimelodidae; bagres marinhos = espécies da família Ariidae; baleia anã = Balaenoptera acutorostrata Lacépède; baleia azul = Balaenoptera musculus Linnaeus; baleia espadarte = Balaenoptera borealis (Lesson); baleia preta = Megaptera novaeangliae (Borowski); baleias = especies das famílias Balaenopteridae e Physeteridae; cachalote $=$ Physeter catodon $\mathrm{Li}-$ nnaeus; cações = espécies da ordem Selachii; camarão branco $=$ Penaeus schimitti Burkenroad; camarão piticaia $=$ Xiphopenaeus kroyeri (Heller); camarão sete barbas $=$ Xiphopenaeus kroyeri (Heller); camarão vermelho $=$ Penaeus aztecus subtilis Pérez Farfante; camarões de águas doces = espécies do gênero Macrobrachium Bate; camarões marinhos = espécies da família Penaeidae; camurupim = Tarpon atlanticus (Valenciennes); cangati = Trachycorystes galeatus (Linnaeus); caranguejo uçá $=$ Ucides cordatus (Linnaeus) ; caranguejos = espécles das famílias Gecarcinidae e Grapsidae; carapebas = Diapterus olisthostomus (Goode \& Bean) e Eugerres brasilianus (Cuvier \& Valenciennes); cavala = Scomberomorus cavalla (Cuvier); corvina $=$ Micropogon furnieri (Desmarest); curimatã comum = Prochilodus sp.; curimatã pacu $=$ Pro- chilodus marcgravii (Walbaum); curimatãs = especies do gênero Prochilodus Agassiz; fidalgo = Megalonema platanus (Gunther); guaiamum = Cardisoma guanhumi (Latreille); jeju = Hoplerythrinus unitaeniatus $($ Spix); lagosta verde $=$ Panulirus laevicauda (Latreille); lagosta vermelha $=$ Panulirus argus (Latreille); lagostas = espécies do género Panulirus Gray; lulas $=$ Loligo brasiliensis Blainville e Loliguncula brevis Blainville; mandi amarelo $=$ Pimelodus maculatus Lacépède $i=P i-$ melodus clarias Lacépède); palombeta = Chloroscombrus chrysurus (Linnaeus); pargo = Lutjanus purpureus Poey; pescada amarela $=$ Cynoscion acoupa (Lacépède); pescadas de águas doces = espécies do gênero Plagioscion Gill; pescadas marinhas $=$ espécies dos gêneros Cynoscion Gill e $M a$ crodon ancylodon (Bloch \& Schneider); piabas = espécies do gênero Astianax Baird \& Girard; piáus $=$ espécies do gênero Leporinus Agassiz; pirá = Conostome conirostris (Valenciennes); pitu = Macrobrachium carcinus (Linnaeus); polvos = Octopus vulgaris Cuvier e Octopus hummelincki Adams; roncador $=$ Conodon nobilis (Linnaeus); samma $=$ Cololabis saira (Brevoort); sardinha bandeira = Opisthonema oglinum (Le Sueur); sardinhas de águas doces $=$ espécies do gênero Triportheus Cope: sardinhas marinhas = espécies da familia Clupeidae; serra = Scomberomorus maculatus (Mitchill); siri canela $=$ Portunus spinimanus (Latreille); siri do mangue $=$ Callinectes bocourti $M$. Edwards; siri guajá $=$ Carpilius corallinus (Herbst) ; siris $=$ espécies das famílias Portunidae e Xanthidae; surubim = Pseudoplatystoma corruscans Agassiz; sururu = Mytella falcata (Orbigny); tainhas $=$ espécies do gềnero Mugil Linnaeus; tilápia = Tilapia melanopleura (Duméril); traíra comum $=$ Hoplias malabaricus $($ Bloch $)$; traíras = espécies da família Erythrinidae; voador $=$ Hirundichthys affinis (Gunther) 